\title{
CREEP OF FROZEN SILT AND CLAY
}

\author{
Francis H. Sayles and Duane Haines
}

\author{
July 1974
}

\author{
UBRARY BRANCH \\ TECINICAL. INFORMATION CENTER \\ US ARMY ENOINEER WATERWAYS EXPERIMENT STATION \\ YICKSHURG, MISSISSIPPI \\ PREPARED FOR \\ DIRECTORATE OF MILITARY CONSTRUCTION \\ OFFICE, CHIEF OF ENGINEERS \\ BY \\ CORPS OF ENGINEERS, U.S. ARMY \\ COLD REGIONS RESEARCH AND ENGINEERING LABORATORY \\ HANOVER, NEW HAMPSHIRE
}




\title{
CREEP OF FROZEN SILT AND CLAY
}

\author{
Francis H. Sayles and Duane Haines
}

\author{
July 1974
}

\author{
PREPARED FOR \\ DIRECTORATE OF MILITARY CONSTRUCTION \\ OFFICE, CHIEF OF ENGINEERS \\ BY \\ CORPS OF ENGINEERS, U.S. ARMY \\ COLD REGIONS RESEARCH AND ENGINEERING LABORATORY \\ HANOVER, NEW HAMPSHIRE
}




\section{PREFACE}

This report was prepared by Francis H. Sayles, Research Civil Engineer, and SP Duane Haines of the Northern Engineering Research Branch, Experimental Engineering Division, U.S. Army Cold Regions Research and Engineering Laboratory. The report is published under DA Project 4A162121A894, Engineering in Cold Environments, Task 23, Cold Regions Earth Materials and Foundation Systems for Military Facilities, Work Unit 002, Stress-Strain-Time Relationships of Frozen Ground Pertinent to Military Construction.

The investigation was under the general direction of K.A. Linell, formerly Chief, Experimental Engineering Division, and the immediate direction of W.F. Quinn, Chief, Northern Engineering Research Branch. Assisting in the investigation were SP D. Moy and Robert Bonnett.

This report was reviewed by Dr. Robert G. Rein, Jr., University of Oklahoma Research Institute, and Dr. G. Swinzow and E. Chamberlain, USA CRREL. The authors wish to thank the reviewers for their constructive suggestions. 


\section{CONTENTS}

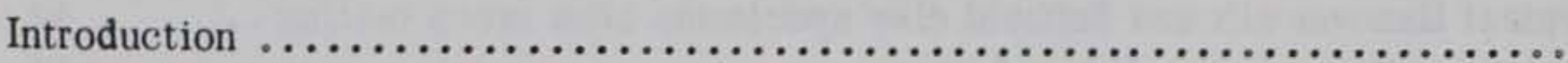

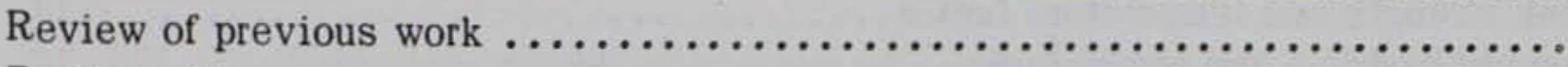



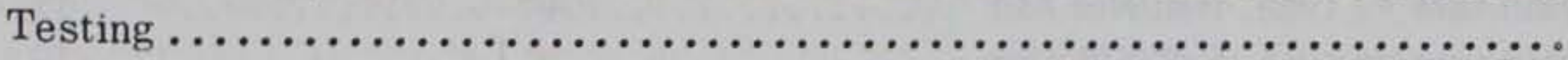

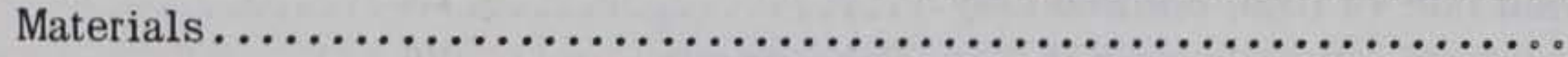

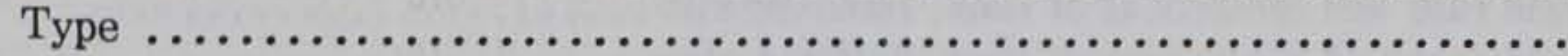





Temperature control $\ldots \ldots \ldots \ldots \ldots \ldots \ldots \ldots \ldots \ldots \ldots \ldots \ldots \ldots \ldots \ldots \ldots \ldots$

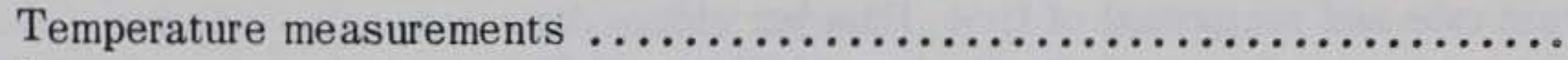

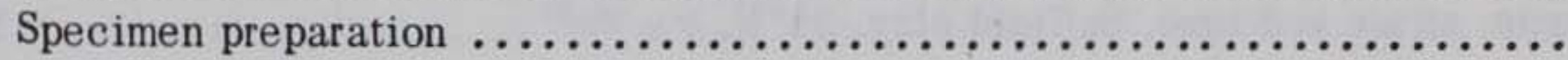

Creep and strength testing procedure $\ldots \ldots \ldots \ldots \ldots \ldots \ldots \ldots \ldots \ldots \ldots \ldots$

Test results $\ldots \ldots \ldots \ldots \ldots \ldots \ldots \ldots \ldots \ldots \ldots \ldots \ldots \ldots \ldots \ldots \ldots \ldots \ldots$

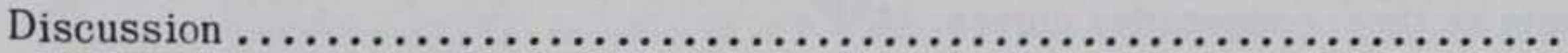

Unconfined compression stress-strain data $\ldots \ldots \ldots \ldots \ldots \ldots \ldots \ldots \ldots$

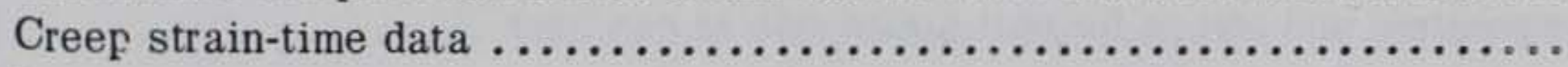

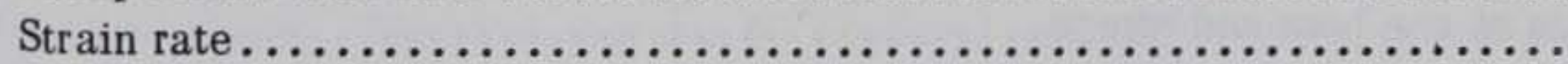

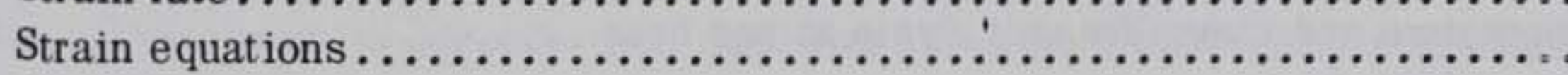

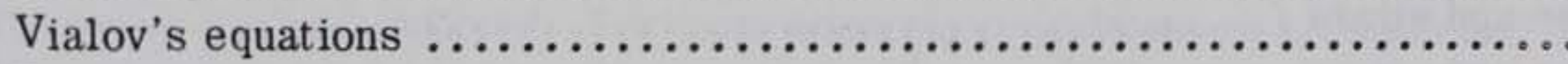

Strain equation based upon strain rate $\ldots \ldots \ldots \ldots \ldots \ldots \ldots \ldots \ldots \ldots \ldots$

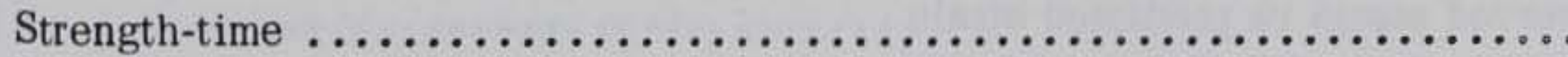

Strength-temperature $\ldots \ldots \ldots \ldots \ldots \ldots \ldots \ldots \ldots \ldots \ldots \ldots \ldots \ldots \ldots$

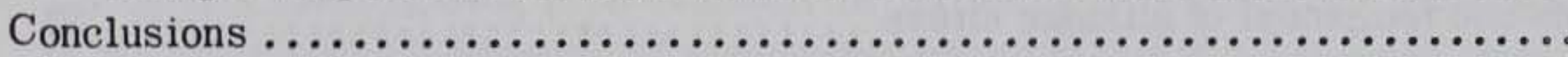

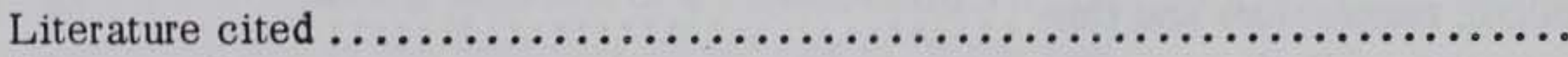

Appendix A. . . . . . . . . . . . . . . . . . . . . . . . . . . . . . . . . .

Appendix B. Method of computing saturation $\ldots \ldots \ldots \ldots \ldots \ldots \ldots \ldots \ldots \ldots$

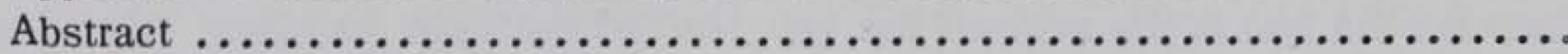

\section{ILLUSTRATIONS}

\section{Figure}

1. Rheological model for creep of frozen soil $\ldots \ldots \ldots \ldots \ldots \ldots \ldots \ldots \ldots \ldots \ldots \ldots \ldots$

2. Gradation curves for Hanover silt and Suffield clay $\ldots \ldots \ldots \ldots \ldots \ldots \ldots . .3$



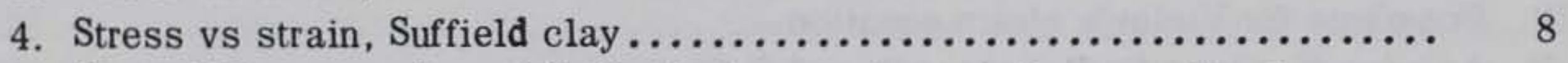

5. Typical Hanover silt and Suffield clay specimens after unconfined com-



6. Creep test in unconfined compression, Suffield clay, $15^{\circ} \mathrm{F} \ldots \ldots \ldots \ldots . .8$

7. Creep tests in unconfined compression, Hanover silt, $15^{\circ} \mathrm{F} \ldots \ldots \ldots \ldots . .9$

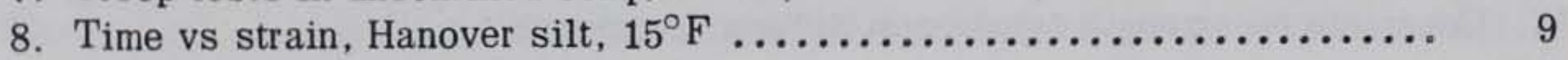

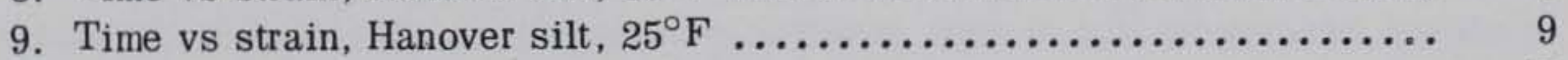

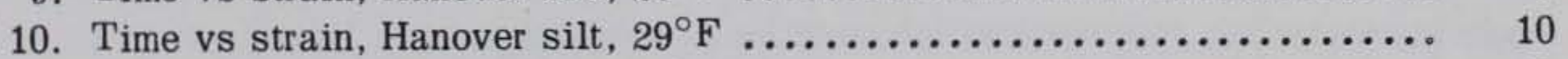

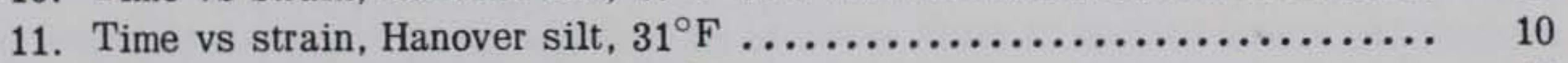

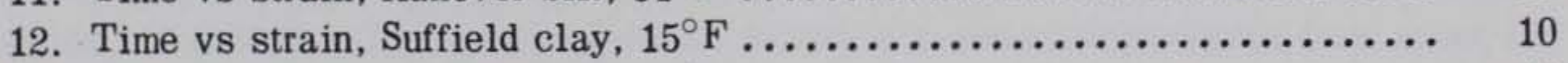

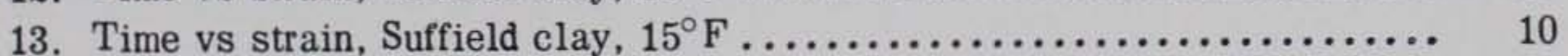


Figure

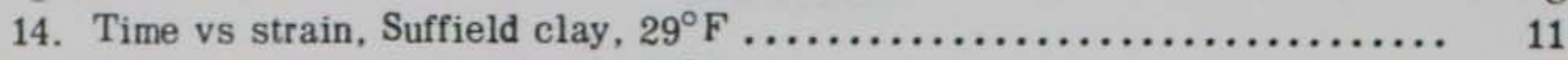



16. Typical Hanover silt and Suffield clay specimens after creep testing .... 12

17. Peak strength and temperature factor $\ldots \ldots \ldots \ldots \ldots \ldots \ldots \ldots \ldots \ldots \ldots \ldots \ldots$

18. Tangent modulus and temperature $\ldots \ldots \ldots \ldots \ldots \ldots \ldots \ldots \ldots \ldots \ldots \ldots \ldots$

19. Strain rate vs time, Hanover silt $\ldots \ldots \ldots \ldots \ldots \ldots \ldots \ldots \ldots \ldots \ldots \ldots \ldots$

20. Strain rate vs time, Suffield clay $\ldots \ldots \ldots \ldots \ldots \ldots \ldots \ldots \ldots \ldots \ldots \ldots \ldots .16$

21. Strain rate and reciprocal of time, Hanover silt $\ldots \ldots \ldots \ldots \ldots \ldots \ldots \ldots \ldots$

22. Strain rate and reciprocal of time, Suffield clay . . . . . . . . . . . . 17



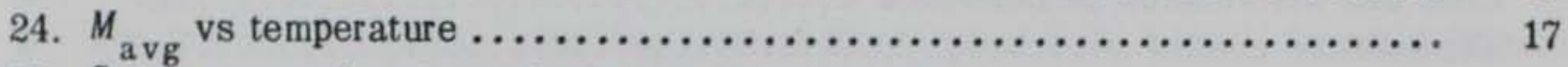

25. Strain rate and reciprocal of time, Hanover silt $\ldots \ldots \ldots \ldots \ldots \ldots \ldots \ldots \ldots$

26. Stress, strain and time, Suffield clay, $31^{\circ} \mathrm{F}, \sigma=A \epsilon^{m} \ldots \ldots \ldots \ldots \ldots \ldots$

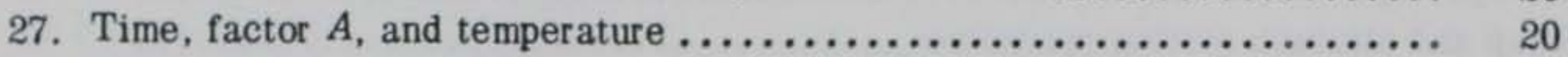



29. Strain vs time, comparative curves, $15^{\circ} \mathrm{F} \ldots \ldots \ldots \ldots \ldots \ldots \ldots \ldots \ldots \ldots \ldots 21$

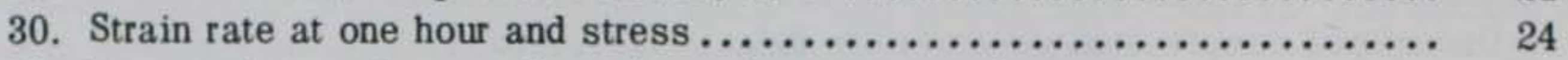

31. Temperature and stress for unit strain rate at one hour $\ldots \ldots \ldots \ldots \ldots \ldots \ldots$

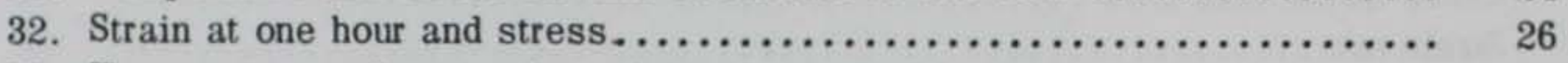

33. Temperature and stress for unit strain at one hour $\ldots \ldots \ldots \ldots \ldots \ldots \ldots \ldots$

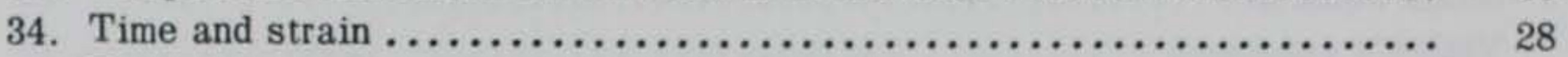

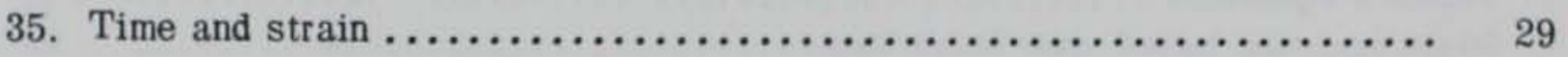

36. Observed strain vs predicted strain $\ldots \ldots \ldots \ldots \ldots \ldots \ldots \ldots \ldots \ldots \ldots \ldots \ldots . \ldots \ldots$

37. Ultimate strength and time to failure $\ldots \ldots \ldots \ldots \ldots \ldots \ldots \ldots \ldots \ldots \ldots \ldots \ldots$

38. Time and reciprocal of ultimate stress $\ldots \ldots \ldots \ldots \ldots \ldots \ldots \ldots \ldots \ldots \ldots \ldots$

39. Strength, temperature and time $\ldots \ldots \ldots \ldots \ldots \ldots \ldots \ldots \ldots \ldots \ldots \ldots \ldots \ldots$





\section{TABLES}

Table

I. Tangent modulus and maximum stress for different temperatures and

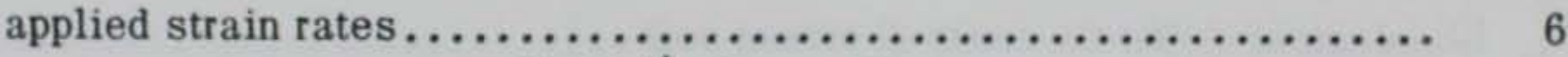

II. Constants for equation $\sigma_{\mathrm{p}}=A\left(\theta / \theta_{0}\right)^{b} ;\left(\theta_{0}=1^{\circ}\right) \ldots \ldots \ldots \ldots \ldots \ldots \ldots \ldots \ldots$

III. Value of $m$ in Vialov's strain equation $\ldots \ldots \ldots \ldots \ldots \ldots \ldots \ldots \ldots \ldots \ldots \ldots$

IV. Constants for Vialov's strain equation $\ldots \ldots \ldots \ldots \ldots \ldots \ldots \ldots \ldots \ldots \ldots \ldots, 21$

V. Average $M$ values for Hanover silt and Suffield clay . . . . . . . . . . . 22



VII. Comparison between predicted and observed strain . . . . . . . . . . 30

VIII. Long-term unconfined compréssive strength $\ldots \ldots \ldots \ldots \ldots \ldots \ldots \ldots \ldots \ldots \ldots . \quad 32$

IX. Constants for strength equation at different temperatures $\ldots \ldots \ldots \ldots \ldots \ldots$ 


\title{
CREEP OF FROZEN SILT AND CLAY
}

\author{
by
}

Francis H. Sayles and Duane Haines

\section{INTRODUCTION}

The design of stable structures in permafrost requires a knowledge of the strength and deformation characteristics of frozen soil. These characteristics depend directly or indirectly upon the type of soil, its structure, density, amount of ice, mineral type and temperature, and the magnitude and type of loading. The types of soil in nature in the general groupings of sand, silt and clay offer an almost infinite number of combinations of particle size and shape, density, surface area, and ice or water content. The most that can be expected from an engineering study of these general types of soil is that it will identify their dominant parameters and relate them empirically so that general behavior can be predicted. For more accurate predictions of strength and deformational behavior a detailed study of the specif ic natural soil is required, taking into consideration all in-situ conditions including the geology of the area.

The purpose of this investigation is to evaluate the influence of temperature and static stress on the strength and deformational behavior of a saturated frozen clay and a saturated frozen silt, and to provide data for use in the design of structures in frozen soil.

This report presents the results and interpretation of unconfined compression creep tests performed on frozen, saturated, remolded Suffield clay and Hanover silt at four different temperatures from $15^{\circ}$ to $31^{\circ} \mathrm{F}\left(-9.44^{\circ}\right.$ to $\left.-0.55^{\circ} \mathrm{C}\right)$. It covers the second phase of the current investigation of the strength and deformational behavior of frozen soil; the first phase was reported in CRREL Technical Report 190, Creep of Frozen Sands.

\section{REVIEW OF PREVIOUS WORK}

Prior to 1952 the published material on the strength and deformation of frozen soil was of Russian origin and was generally incomplete in the description of soils and testing details. In 1952, the Arctic Construction and Frost Effects Laboratory published a report summarizing experimental data obtained up to that time, including the results of ACFEL investigations. Tsytovich $(1954,1958)$ and Vialov $(1959,1962,1963)$ published rather complete experimental data on the strength and deformation properties and the testing details of some naturally frozen, undisturbed silts and clays. In addition, they summarized and formulated qualitative theories and empirical equations relating strength and deformation of frozen soils to soil temperature and duration of the applied load. Sanger and Kaplar (1963) published deformation data and empirical equations relating unconfined compression creep and rate of creep strain to applied stress and temperature. This investigation included a variety of soils, tested at various temperatures from about $18^{\circ}$ 
to $32^{\circ} \mathrm{F}\left(7.8^{\circ}\right.$ to $\left.0^{\circ} \mathrm{C}\right)$. The creep tests were limited to 60 hours' duration. Andersland and Akili (1967) performed unconfined compression creep tests on a partially saturated frozen clay and arrived at an activation energy of $93.1 \mathrm{kcal} / \mathrm{mole}$ for a uniaxial stress range of 600 to $800 \mathrm{psi}$ (4.14 to $\left.5.5 \mathrm{MN} / \mathrm{m}^{2}\right)$ and temperature range of $-0.4^{\circ}$ to $+10.4^{\circ} \mathrm{F}\left(-18^{\circ}\right.$ to $\left.-12^{\circ} \mathrm{C}\right)$. An empirical equation for strain rate was presented. This equation was based on a general equation for true creep rate for metals by Kauzmann (1941) and Conrad (1961). A graphic technique for evaluating constants in this equation was suggested.

Goughour and Andersland (1968) published unconfined compression strength and creep data for ice samples and Ottawa sand-ice samples with ratios ranging from 0 to $61.2 \%$ sand by volume. An equation which related the creep rate to stress, temperature, strain and strain energy was fitted to the ice sample data. Using the empirical equation for ice and unconfined compression stress-strain curves for Ottawa sand-ice samples, creep curves for sand-ice samples were plotted by means of stress factors. Stress factors were related to the percent of sand by volume. Data on ice for elastic strain recovery for $24.8^{\circ}, 19.4^{\circ}$ and $10.4^{\circ} \mathrm{F}\left(-4^{\circ},-7^{\circ}\right.$ and $\left.-12^{\circ} \mathrm{C}\right)$ showed that Young's modulus decreased with plastic strain and with decreasing temperature. Sanger (1968) summarized mechanical properties used in design of structures in frozen soil.

The unconfined compression creep strength and creep deformation of frozen Ottawa sand, Manchester fine sand and columnar-grained ice at $31^{\circ}$ to $15^{\circ} \mathrm{F}\left(-0.56^{\circ}\right.$ to $\left.-9.45^{\circ} \mathrm{C}\right)$ were investigated by Sayles (1968). Predictions of creep strength and creep deformation made using Vialov's methods compared reasonably well with the test data for these sands. A simplified method for predicting the amount of creep deformation was formulated and it also predicted deformations which compared favorably with the test data for the sands. The work presented here is an extension of the study on sands to include the creep of remolded fine-grained soils.

\section{REVIEW OF THEORY}

A qualitative explanation of the physical process of creep in frozen soil by Vialov and Tsytovich (1955) attributes the deformation to: pressure melting of the ice in the soil at points of soil grain contact, migration of unfrozen water to regions of lower stress, breakdown of the ice and structural bonds to the soil grain, plastic deformation of pore ice, and a readjustment in the particle arrangement. During the creep process there is both a strengthening due to denser packing of soil particles (i.e. increased number of firm contacts between soil particles) and a weakening caused by a reduction in the cohesion and an increase in the amount of unfrozen water in the frozen soil. All of the action described is generally time-dependent and is referred to by using the timedependent term creep.

Different authors have suggested that frozen soil be represented by mechanical models designed to duplicate the observed time dependence. Of course, these rheological models describe only the overall behavior of the soil sample and tell nothing of the detailed mechanisms that underlie this behavior. One such model proposed by Vialov (1959) is shown in Figure 1. It is essentially a Voigt-Kelvin unit in series with a Maxwell unit and a blocking device. Although Vialov's model does not include the initial plastic deformation or the third stage of creep of the classical creep curve, it does produce a creep curve that is similar in shape to experimental creep curves for the frozen silt and clay tested in the investigation covered by this report. Vialov (1962) applied the theory of hereditary creep to frozen soils in an effort to account for the influence of the stress or deformational history of the soil on its response to future loads. 


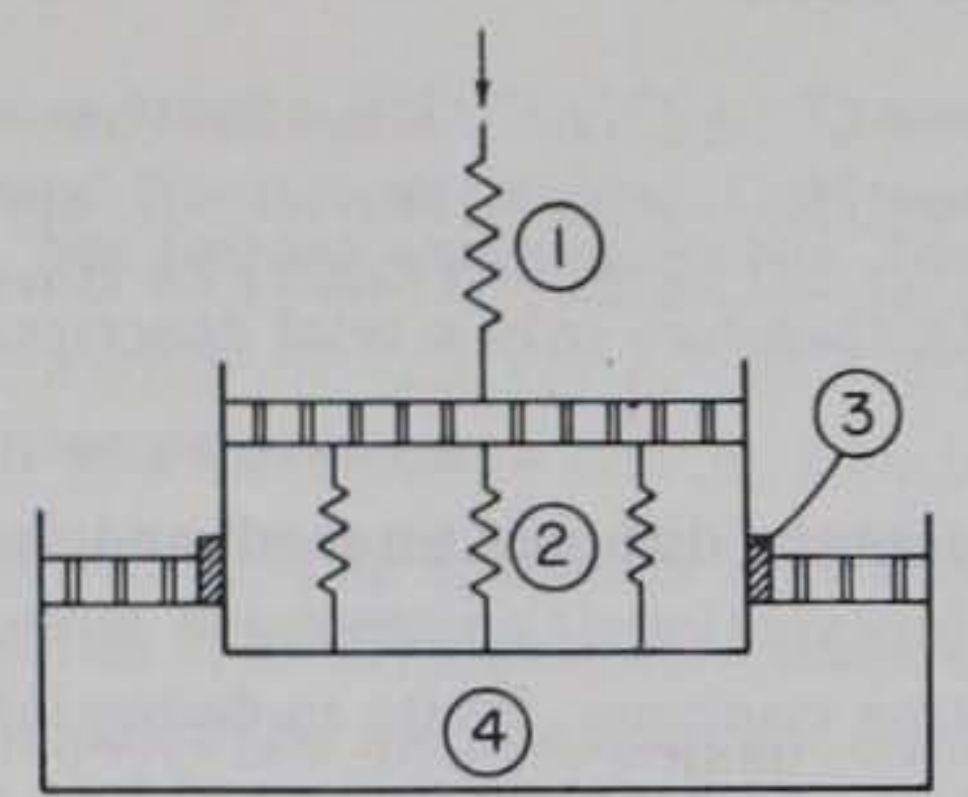

1. SPRING (ELASTIC DEFORMATION)

2. SPRING-DASHPOT OR VOIGT-KEL VIN ELEMENT (VISCOELASTIC DEFORMATION)

3. BLOCKING DEVICE (SLIDES WHEN FORCE EXCEEDS A MINIMUM LIMIT)

4. DASHPOT (VISCOUS DEFORMATION).

Figure 1. Rheological model for creep of frozen soil (after Vialov).

U. S. Standard Sieve Size

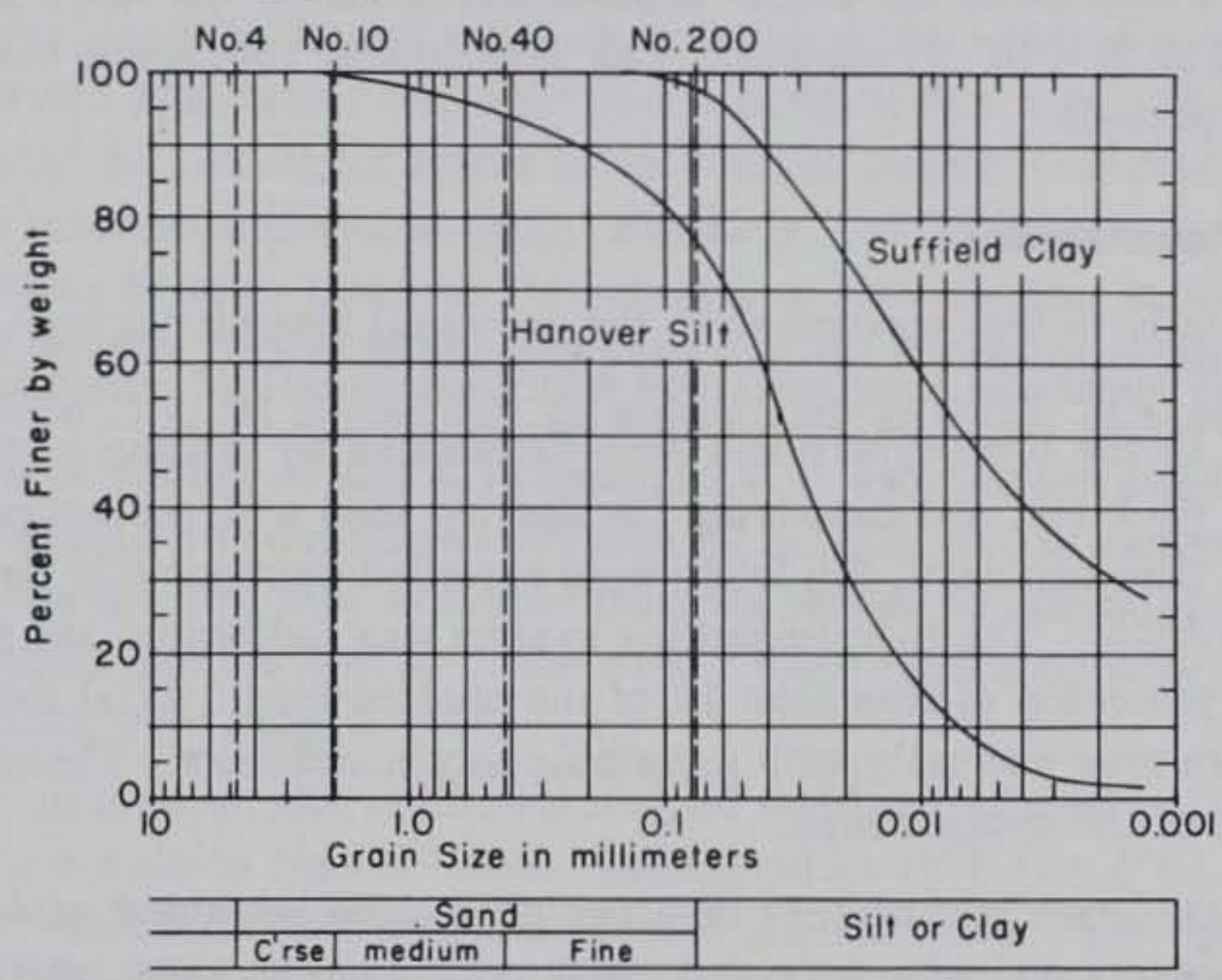

SOIL $\frac{\text { CLASSIFICATION }}{\text { SANDY SILT (ML) }} \frac{\text { SAT WC }}{31} \frac{L L}{\text { NP NP }} \frac{P L}{\text { NP }} \frac{P I}{2.74}$

HANOVER SILT SILTY CLAY $(C L) \quad 37 \quad 35 \quad 20 \quad 15 \quad 2.69$

Figure 2. Gradation curves for Hanover silt and Suffield clay.

\section{TESTING}

\section{Materials}

Frozen Hanover silt (sandy silt - ML) and Suffield clay (silty clay - CL) were the materials tested. The gradation curves and classification data for these soils are shown in Figure 2. All Hanover silt and Suffield clay spacimens were remolded to near the in-situ density of the unfrozen soil, then saturated and frozen in one direction. Densities, water (ice) content, void ratio and porosity for each test specimen are listed in Appendix A.

\section{Type}

The unconfined compression test was chosen for this investigation because of its simplicity, its suitability for adoption as a field laboratory test, and its comparability with previous tests on other frozen soils. 


\section{Apparatus}

The freezing facilities, freezing molds, loading equipment, and temperature control and measuring systems were described in detail by Sayles (1968); therefore only a brief description of them will be presented here.

Four types of loading equipment were used to accommodate the different strength and deformation characteristics of the frozen soils. The instantaneous (conventional) compressive strength tests were performed on a mechanically driven universal testing machine. Tests to determine the short-term creep strength of frozen soils with relatively high resistance were performed in a 20,000 lb $\left(9.0 \times 10^{4} \mathrm{~N}\right)$ capacity air-actuated hydraulic press. This press was capable of maintaining a vibration-free constant load within $2 \%$ of the applied load for loads greater than $3000 \mathrm{lb}$ for long periods. A constant stress apparatus was used for creep tests in which large deformations occurred at loads less than $4000 \mathrm{lb}\left(1.8 \times 10^{4} \mathrm{~N}\right)$. This press featured a programming cam that maintained constant axial stress within $1 \%$ of the initial applied stress during the tests (Sayles 1963). A lever-type press [2000 lb $\left(9 \times 10^{3} \mathrm{~N}\right)$ capacity] was used to test specimens that experience small deformation over long periods.

\section{Load and deformation measurement}

Loads applied axially to test specimens in the universal testing machine, the hydraulic press, and the constant stress apparatus were measured with load-electrical transducers of the appropriate range. Loads applied by the lever-type press were determined by placing a load cell in the specimen test space before each test and measuring the applied load with the hanger weights in place. For tests lasting less than two days, the loads were recorded continuously for the first hour and every ten minutes thereafter. The load measuring system was calibrated and the recorded loads were measured with a precision of less than $1 \%$ of the applied load. Axial loads for tests lasting two days or longer were read manually with a portable strain indicator. These measurements were precise to within $0.3 \%$ of the applied load.

Deformations for the tests lasting less than two days were measured using resistance-type linear motion potentiometers and were recorded continuously at the same intervals as the loads. The use of calibration charts allowed these deformations to be measured with a precision of $0.0025 \mathrm{in}$. for total movements less than $0.25 \mathrm{in}$. For the longer tests, using the constant stress apparatus and the lever-type press, the deformations were measured with dial indicators having $10^{-4}$ in. $\left(2.54 \times 10^{-3} \mathrm{~mm}\right)$ graduations and a sensitivity of $2 \times 10^{-5}$ in. $\left(5.08 \times 10^{-4} \mathrm{~mm}\right)$.

\section{Temperature control}

Test temperatures were controlled by heating and circulating air within insulated test enclosures located in the walk-in coldrooms. Each test specimen was housed in a plastic hollow cylinder to reduce temperature fluctuations of the air surrounding it. Heat was applied by positioning light bulbs in the airstream of a fan. Temperature was regulated by a mercury column thermoregulator which activated a relay to supply heat upon demand.

During normal operations, air temperatures within the plastic enclosures surrounding the test specimens were held well within $\pm 0.1^{\circ} \mathrm{F}\left(0.055^{\circ} \mathrm{C}\right)$ of the desired temperature.

\section{Temperature measurements}

The temperature of the air surrounding the test specimen was sensed by a thermistor and readings were recorded every $1 \frac{1}{4} \mathrm{~min}$ on a 12 -point $\mathrm{L} \& \mathrm{~N}$ type $\mathrm{H}$ recorder. Test temperatures above $25^{\circ} \mathrm{F}\left(-3.89^{\circ} \mathrm{C}\right)$ were measured to $0.1^{\circ} \mathrm{F}\left(0.055^{\circ} \mathrm{C}\right)$ and test temperatures below $25^{\circ} \mathrm{F}$ were measured 
to the nearest $0.2^{\circ} \mathrm{F}\left(0.11^{\circ} \mathrm{C}\right)$. Thermistor readings were checked twice daily using a manually operated Wheatstone bridge. Coldroom temperatures (outside the enclosures) were recorded continuously to within $1^{\circ} \mathrm{F}\left(0.55^{\circ} \mathrm{C}\right)$.

\section{Specimen preparation}

Molding. The specimen mold was a 7-in.-high (17.8-cm) plastic (Plexiglas) block in which 3-in.-diam $(7.6-\mathrm{cm})$ holes were bored and fitted with split sleeves. The sleeves allowed the specimens to be ejected from the mold without being subjected to the ejection force. The assembled mold permitted the evacuation and saturation of the soil specimens before freezing. To reduce friction during ejection from the mold the outsides of the split sleeves were coated with silicone grease. The soil specimens were not in direct contact with the grease. However, the split in the forming sleeve allowed saturating water to contact the silicone grease, thus permitting a slight chance of silicone contamination of the specimens.

After the mold was assembled with the sleeves in position, moist silt or clay soil was tamped in layers using a Harvard Miniature Compactor with a tamping foot $1 \mathrm{in}$. $(25.4 \mathrm{~mm})$ in diameter. The Hanover silt was placed in 1-in.-thick layers at an average moisture content of $13.5 \%$ and each layer was tamped 25 times with the compactor. Similarly, the Suffield clay was placed in five $1 \frac{1}{2}$ in. $(38.1 \mathrm{~mm})$ thick loose layers. However, to obtain a uniform density in the clay, the number of tamping blows per layer from bottom to top was varied in the following manner: 1st layer (bottom), 20 blows; 2nd, 26 blows; 3rd, 30 blows; 4 th, 32 blows; 'and 5th (top), 45 blows, Specimen unit weights are tabulated in Tables AI and AII (Appendix A). With the top and bottom of the mold sealed, the soil-filled mold was evacuated to about $29 \mathrm{in}$. $(737 \mathrm{~mm})$ of mercury using a water ejection pump, and then the soil was saturated from the bottom by admitting de-aired water under 29 in. of mercury vacuum into the bottom of the mold. When saturation was completed the top and bottom mold connections were sealed.

Freezing. After saturation, the specimen-charged mold was placed in the freezing cabinet which was mounted in a walk-in type coldroom maintained at $40^{\circ} \mathrm{F}\left(+4.4^{\circ} \mathrm{C}\right)$. Spaces between the sides of the mold and the cabinet were insulated with granular cork. The specimens were frozen in an open system by removing the top cover of the mold and connecting the bottom of the mold to a de-aired water supply. In this arrangement the bottoms of the specimens were exposed to $40^{\circ} \mathrm{F}$ $\left(+4.4^{\circ} \mathrm{C}\right)$ temperature with a free water supply, and the tops were exposed to cold, circulating freezing air. The rate of progress of the $32^{\circ} \mathrm{F}\left(0^{\circ} \mathrm{C}\right)$ isotherm was determined by means of thermocouples spaced 1 in. $(25.4 \mathrm{~mm})$ apart along the vertical axis of the center specimen. Hanover silt specimens were frozen within 48 hours by exposing their tops to $-20^{\circ} \mathrm{F}\left(28.9^{\circ} \mathrm{C}\right)$ air. The tops of the Suffield clay specimens were exposed to a pan filled with acetone and dry ice $\left(\mathrm{CO}_{2}\right)$ at $-110^{\circ} \mathrm{F}$ which caused them to freeze within 24 hours. The soil specimens were frozen rapidly in an attempt to minimize ice lensing.

Trimming. After ejection from the mold, each test specimen was inspected for imperfections and cut to a 6 -in. (152-mm) height, and the ends were squared on a lathe in the coldrooms. After the ends were trimmed to final length, the circumference was measured at the top, bottom and midheight and the length was determined by averaging measurements made at six points around the perimeter. Variations in specimen length around the circumference were within \pm 0.003 in. $( \pm 0.076$ $\mathrm{mm})$ of the average. The diameter varied less than \pm 0.002 in. $( \pm 0.051 \mathrm{~mm})$ along the specimen length. The nominal size of the specimens after trimming was $2.8 \mathrm{in} .(71.1 \mathrm{~mm})$ in diameter by 6 in. (152 mm).high.

The volume of each specimen was determined by submergence in liquid iso-octane $(2,2,4$ trimethylpentane) at $20^{\circ} \mathrm{F}\left(-6.67^{\circ} \mathrm{C}\right)$. 
Table I. Tangent modulus and maximum stress for different temperatures and applied strain rates.

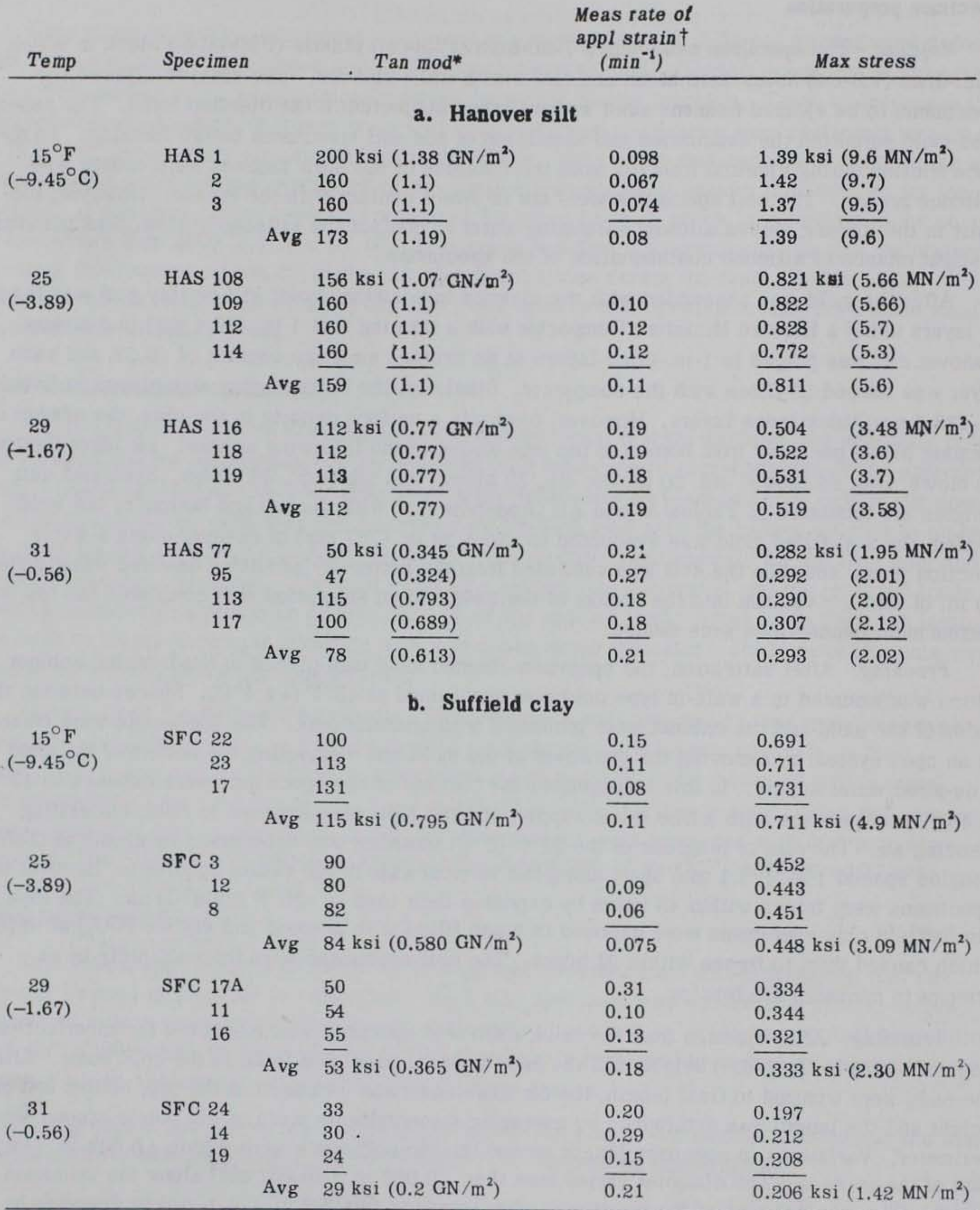

* Tangent modulus at $50 \%$ of maximum stress.

$\dagger$ Average rate of applied strain for Hanover silt $=14.1 \% / \mathrm{min}$ and for Suffield clay $=15.2 \% / \mathrm{min}$. 
Storage and tempering. Prior to preparation for testing, the specimens usually remained in the sealed freezing mold. Occasionally it was necessary to eject several specimens in advance. These specimens were sealed in rubber membranes and temporary end caps, then stored in sealed plastic bags with crushed ice to reduce sublimation. Storage periods did not exceed 6 weeks.

Before testing, all specimens were stored at the testing temperature for a minimum of 24 hours. The required tempering time was checked using three thermocouples embedded at the midpoint and quarter points of the axial height of a control specimen. This check showed that 24 hours was sufficient time for the specimen to reach equilibrium at the test temperature.

\section{CREEP AND STRENGTH TESTING PROCEDURE}

At each test temperature a series of compressive type tests were conducted by first determining the instantaneous strength* of the frozen soil and then performing creep tests at reduced stress levels. Each test series included constant stress or constant load compression tests performed at stress levels of approximately $60,40,20,10$ and $5 \%$ of the average instantaneous strength. One test series was conducted at each of the following test temperatures: $15^{\circ}, 25^{\circ}, 29^{\circ}$ and $31^{\circ} \mathrm{F}$ $\left(-9.45^{\circ},-3.89^{\circ},-1.66^{\circ}\right.$, and $\left.-0.56^{\circ} \mathrm{C}\right)$. Whether constant stress or constant load tests were performed depended upon the magnitude of the applied stress and the expected deformation. Constant load tests were used for high and low stress levels where small deformations were expected, while constant stress tests were performed at intermediate stress levels (i.e. in the range of 15 to $40 \%$ of instantaneous strength) where the deformations were expected to be large.

The compression creep test on each specimen was performed by first applying a seating load of approximately $2 \mathrm{psi}\left(1.38 \times 10^{4} \mathrm{~N} / \mathrm{m}^{2}\right)$ to the specimen to insure positive contact between it and the components of the loading system, and then applying the test load in less than 2 seconds. Instantaneous strengths were determined by loading the silt specimens at an average applied strain rate of $0.14 / \mathrm{min}$ and the clay specimens at $0.15 / \mathrm{min}$ (see Table I). After each test was completed, photographs were taken of the test specimens and water contents were determined.

\section{TEST RESULTS}

Typical stress-strain curves for unconfined compression tests performed on Hanover silt and Suffield clay are shown in Figures 3 and 4. The maximum stress clearly increases with decreasing temperature. Photographs of typical specimens after testing are shown in Figure 5. These specimens were deformed far beyond the failure strain to show the mode of failure more clearly. The loading platens were large enough to allow the specimen diameter to increase during the test without the platen penetrating the end of the specimen until after a strain of $30 \%$ had been reached.

Figures 6 and 7 show typical time-deformation curves for Suffield clay and Hanover silt specimens subjected to the unconfined compression creep test. The time-strain curves in Figures 8-15 summarize the data for Hanover silt and Suffield clay. When more than one specimen number is shown on a single curve, the curve represents the average of the curves obtained for the specimens indicated and the vertical bars indicate the total range of values. The percentage values in the tables indicate the percent of the instantaneous strength at which the creep tests were performed. Photographs of typical test specimens after creep testing are shown in Figure 16 and a summary of unit weight data for each individual specimen is given in Appendix A.

* "In stantaneous" strength as used here is the maximum resistance determined by loading the test specimen at a constant rate of strain of about $0.15 / \mathrm{min}$. 


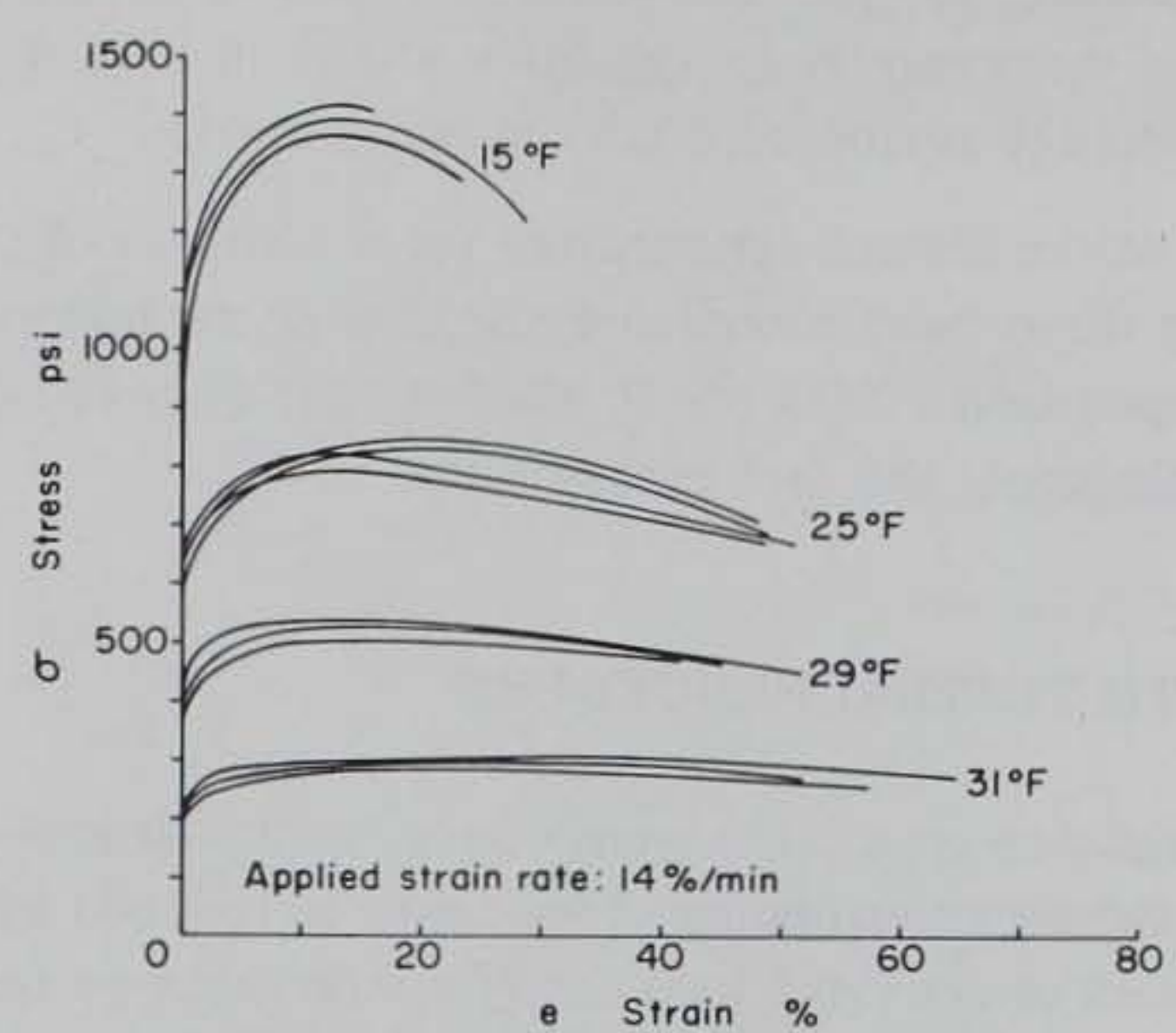

Figure 3. Stress vs strain, Hanover silt. (Instantaneous strength.)



Figure 4. Stress vs strain, Suffield clay. (Instantaneous strength.)
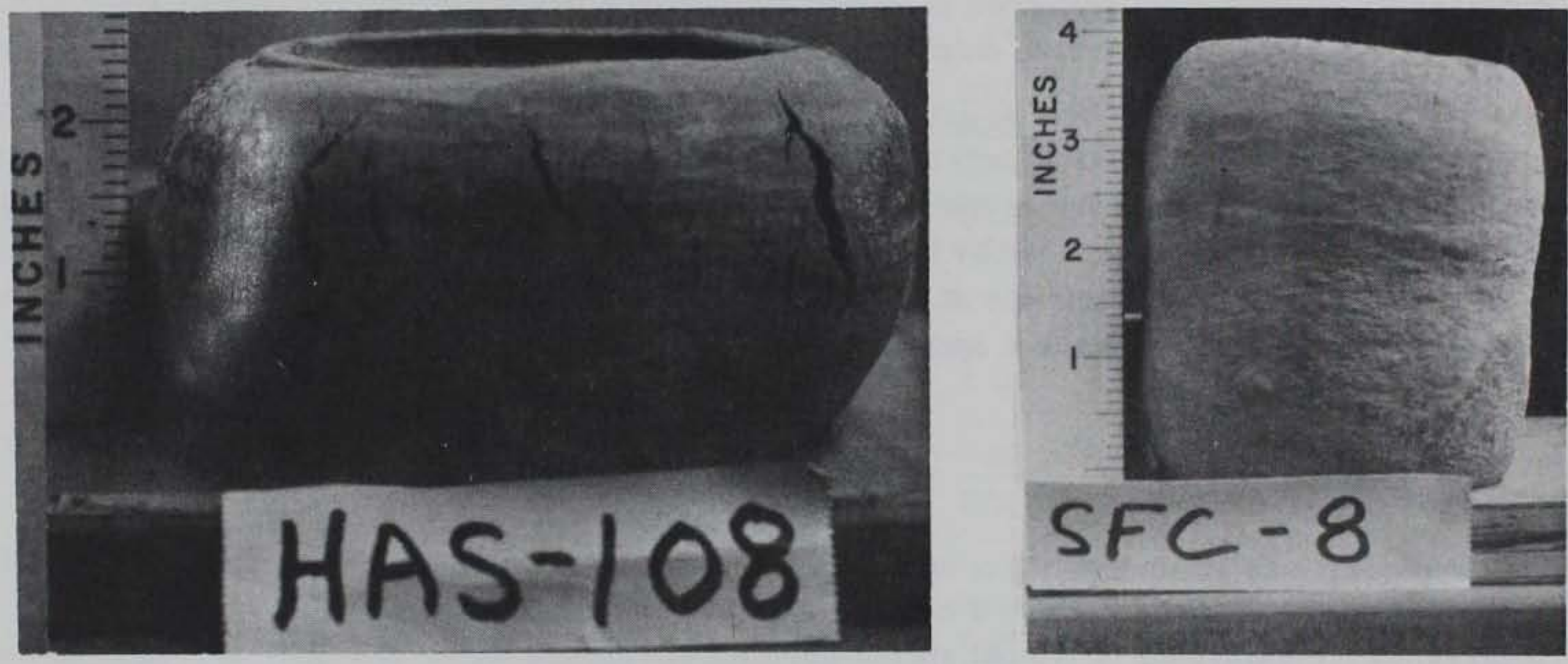

Figure 5. Typical Hanover silt and Suffield clay specimens after unconfined compression testing. .

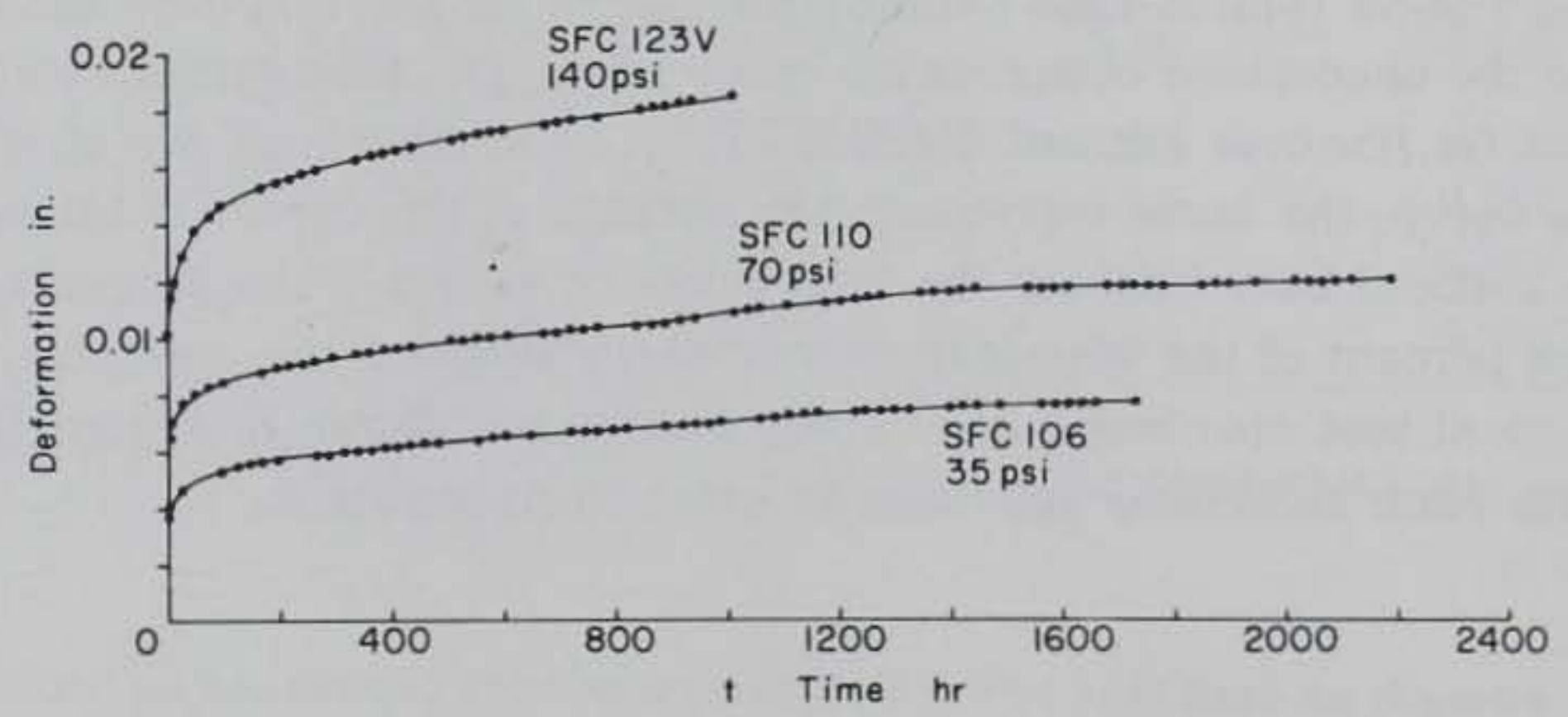

Figure 6. Creep test in unconfined compression, Suffield clay, $15^{\circ} \mathrm{F}$. 



Figure 7. Creep test in unconfined compression, Hanover silt, $15^{\circ} \mathrm{F}$.



Figure 8. Time vs strain, $H$ anover silt, $15^{\circ} \mathrm{F}$.

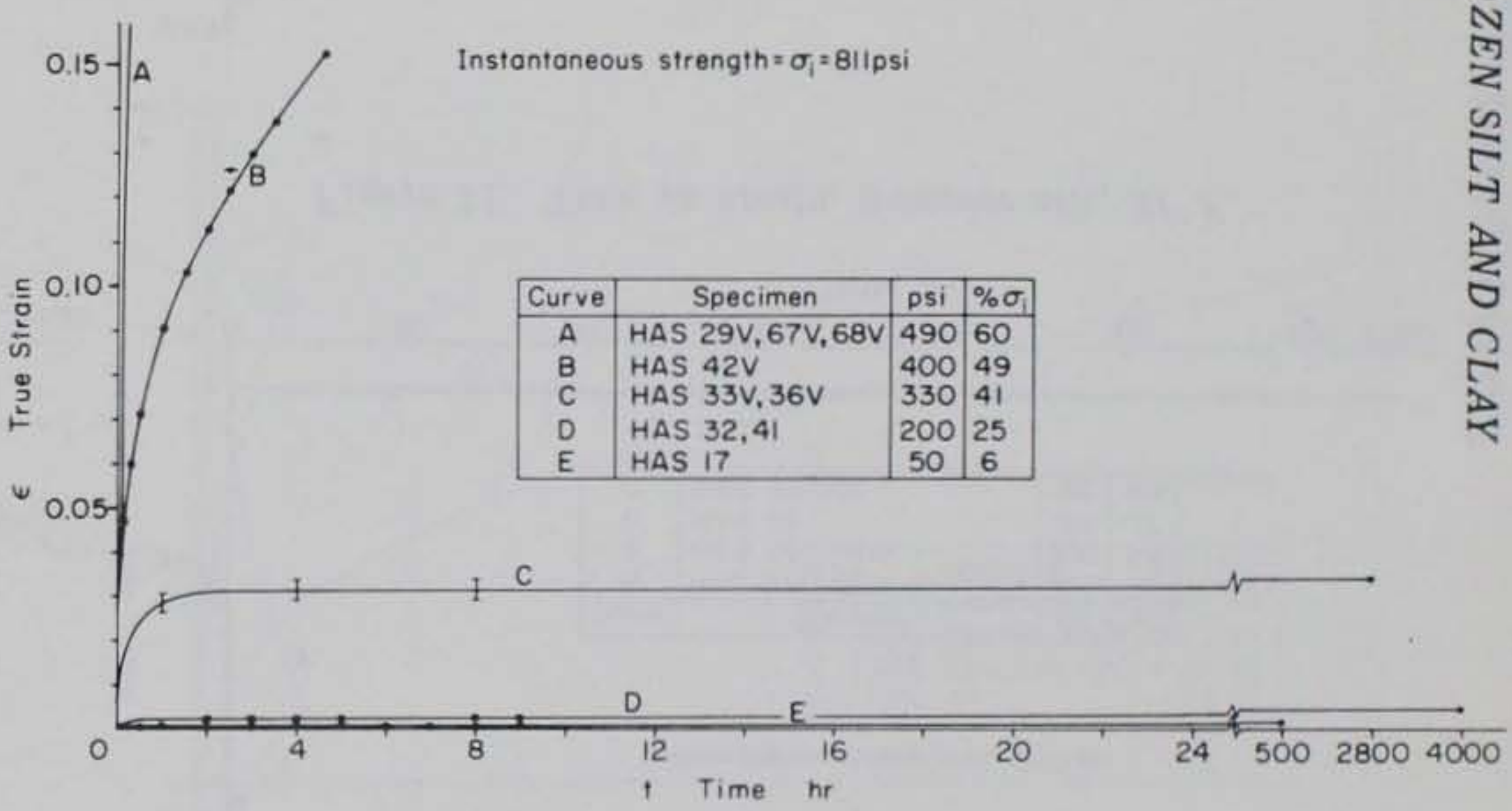

Figure 9. Time vs strain, Hanover silt, $25^{\circ} \mathrm{F}$. 




Figure 10. Time vs strain, Hanover silt, $29^{\circ} \mathrm{F}$.

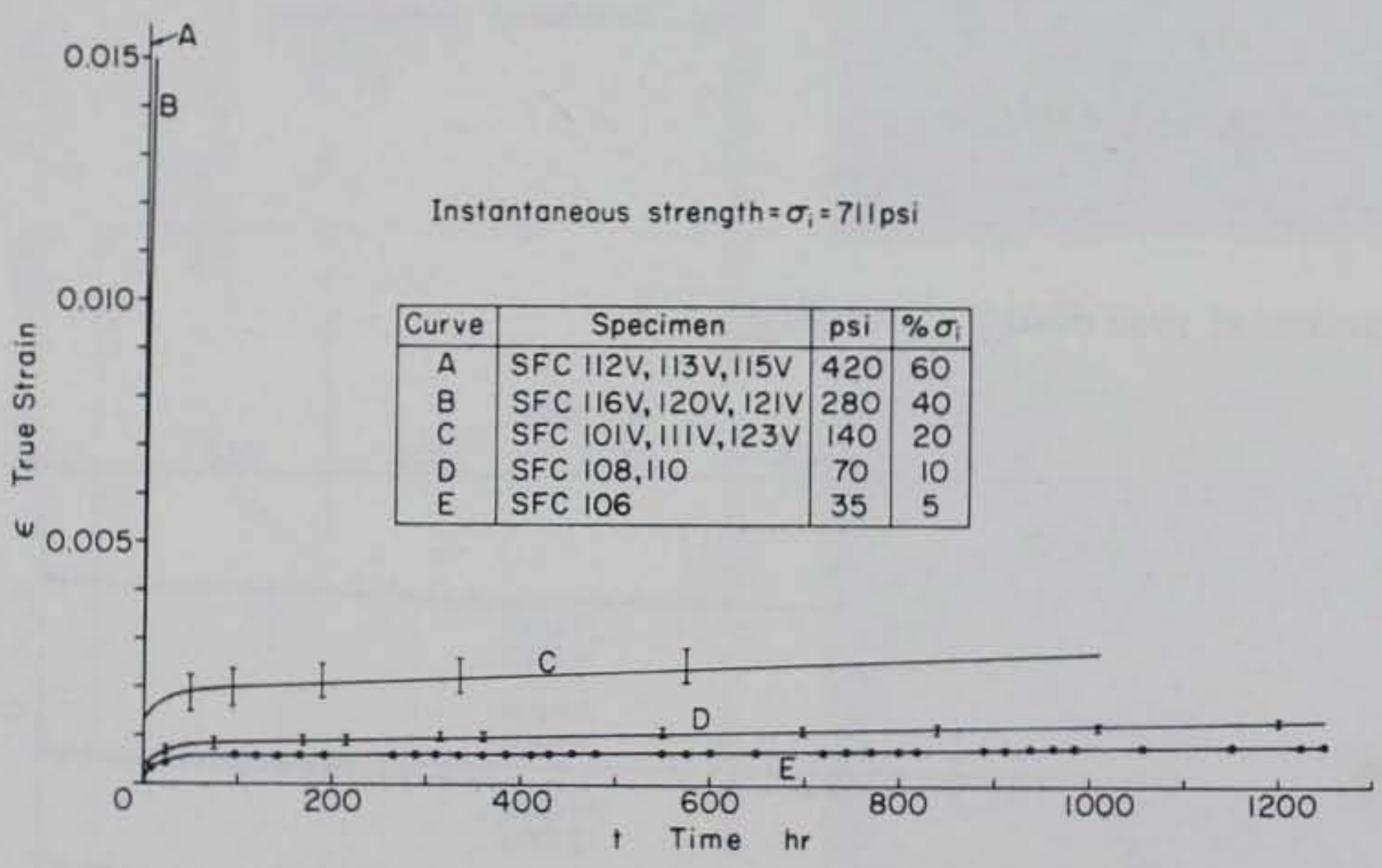

Figure 12. Time vs strain, Suffield clay, $15^{\circ} \mathrm{F}$.

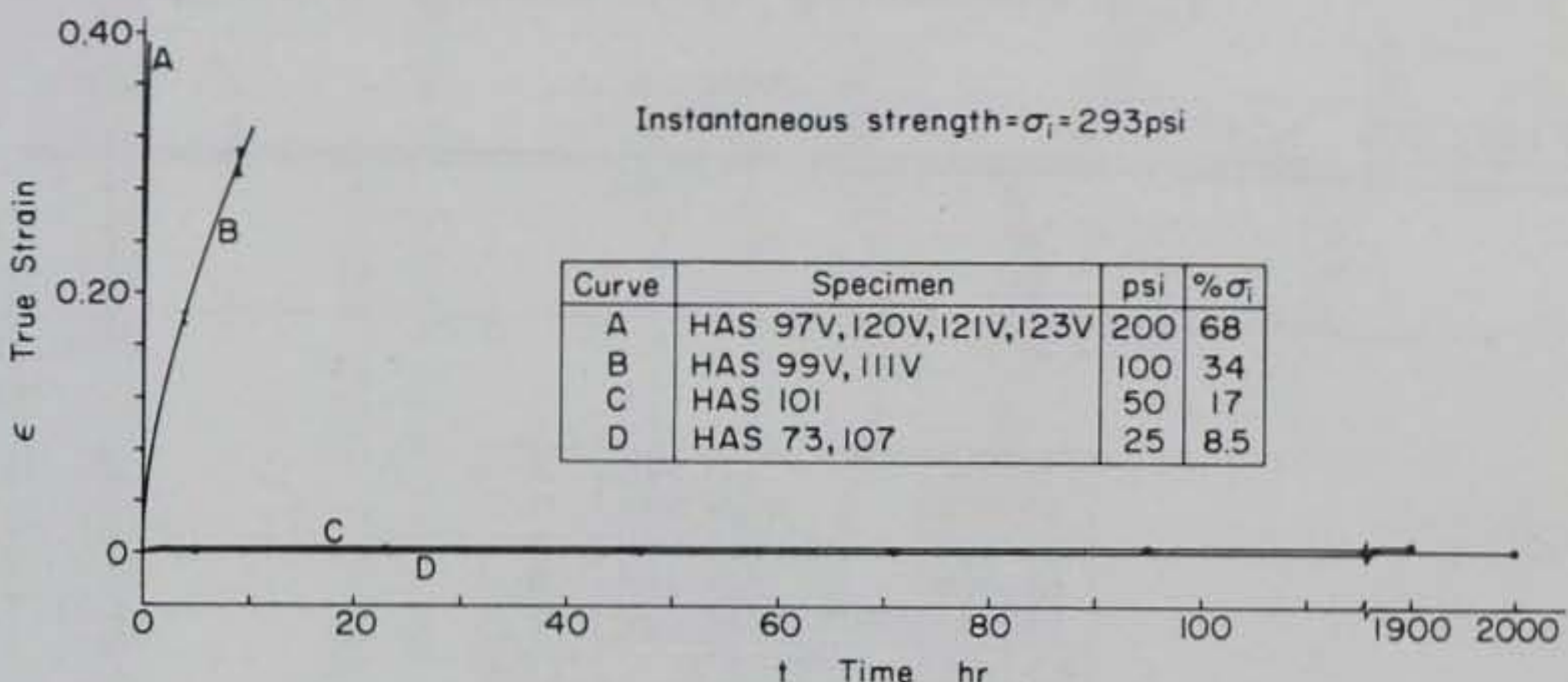

Figure 11. Time vs strain, Hanover silt, $31^{\circ} \mathrm{F}$.

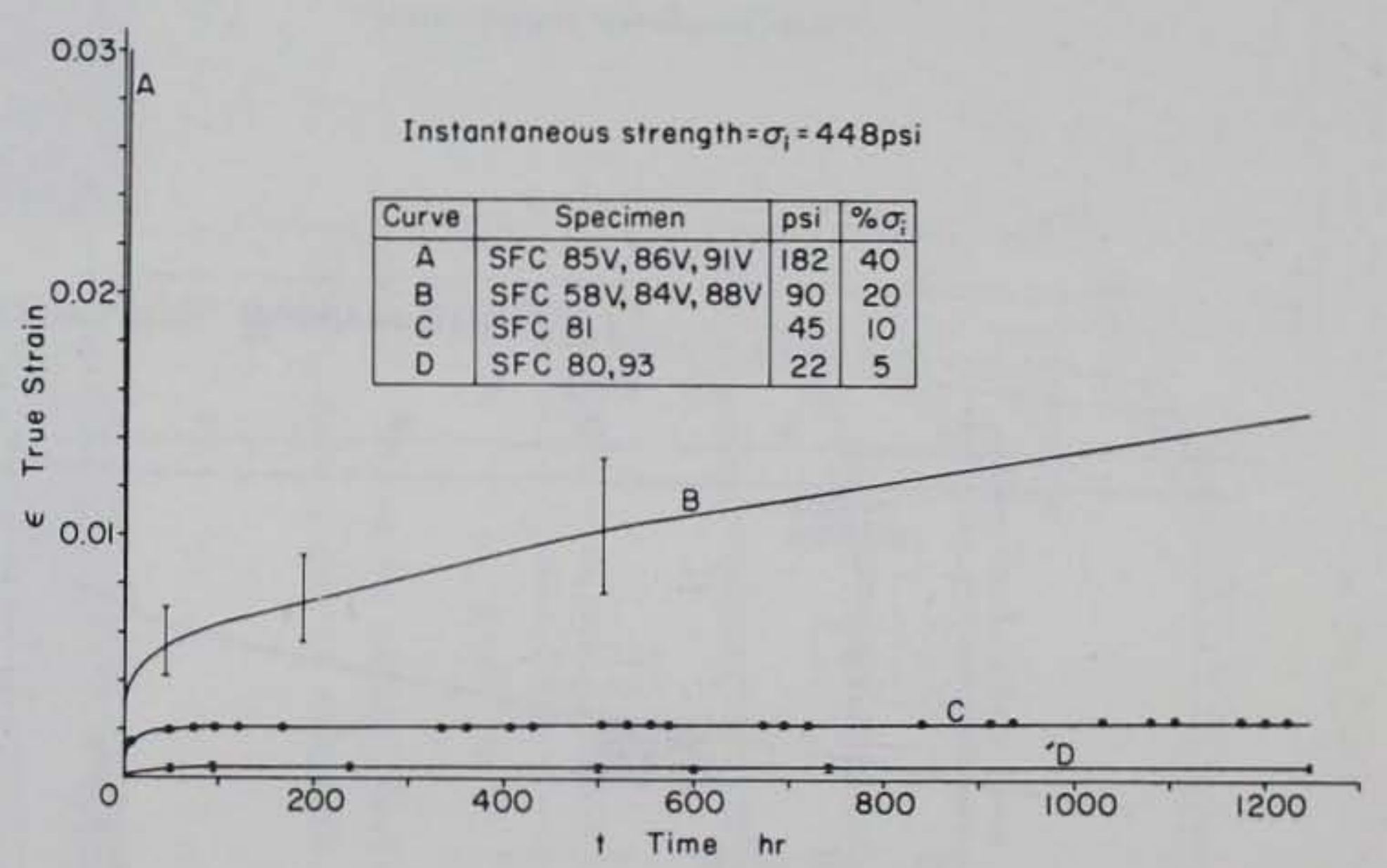

Figure 13. Time vs strain, Suffield clay, $25^{\circ} \mathrm{F}$. 

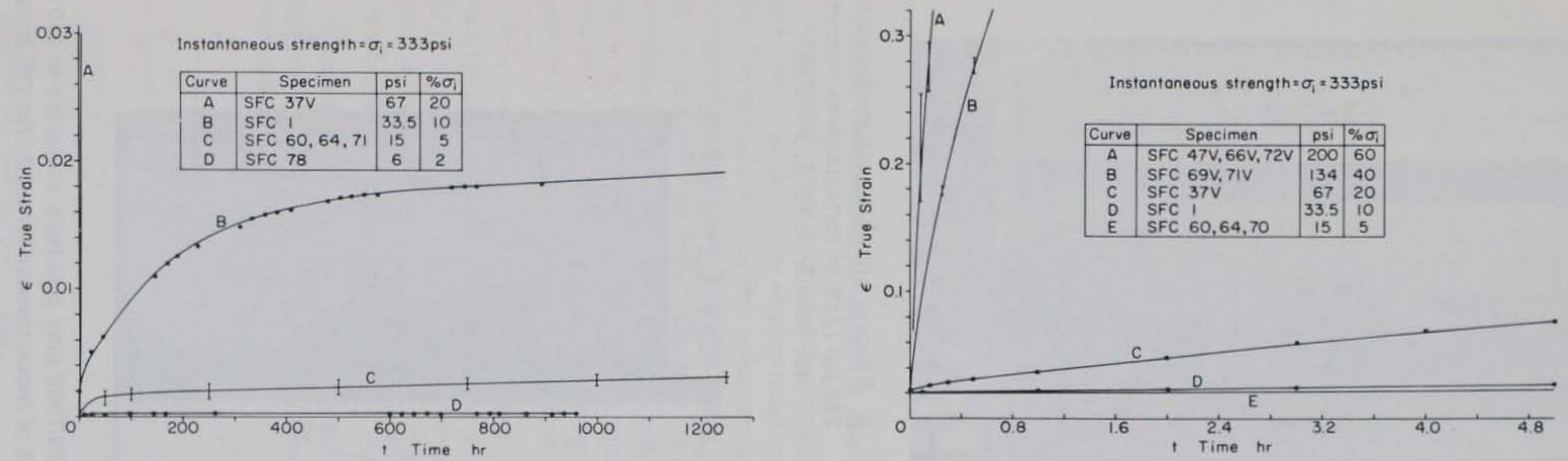

Figure 14. Time vs strain, Suffield clay, $29^{\circ} \mathrm{F}$.
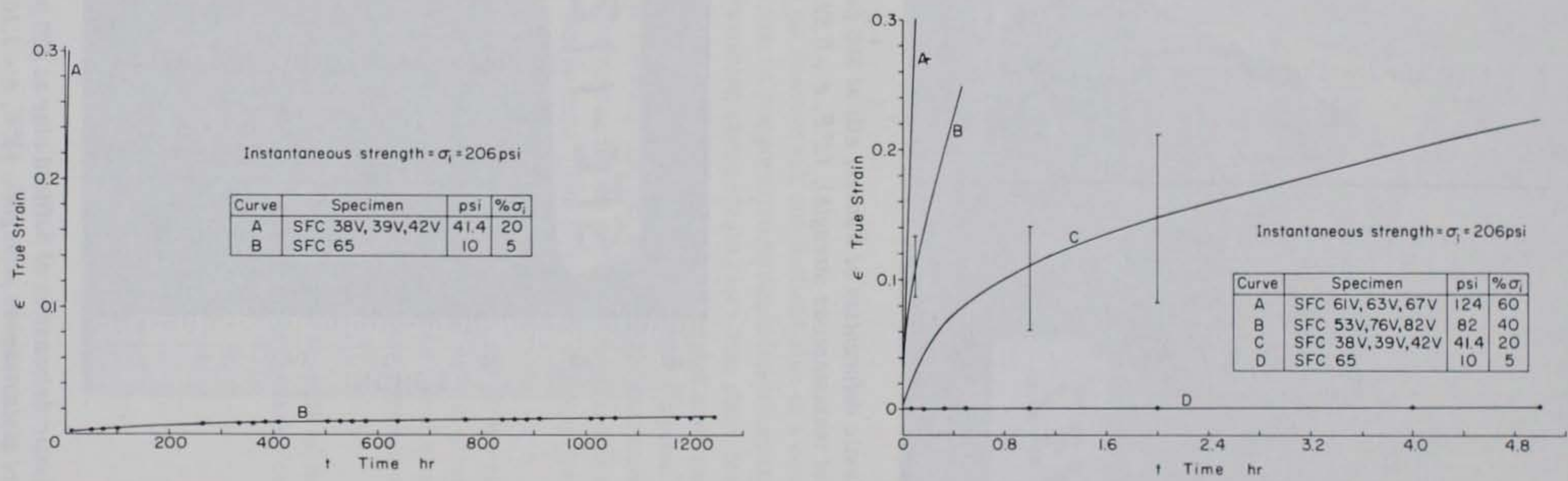

Figure 15. Time vs strain, Suffield clay, $31^{\circ} \mathrm{F}$. 


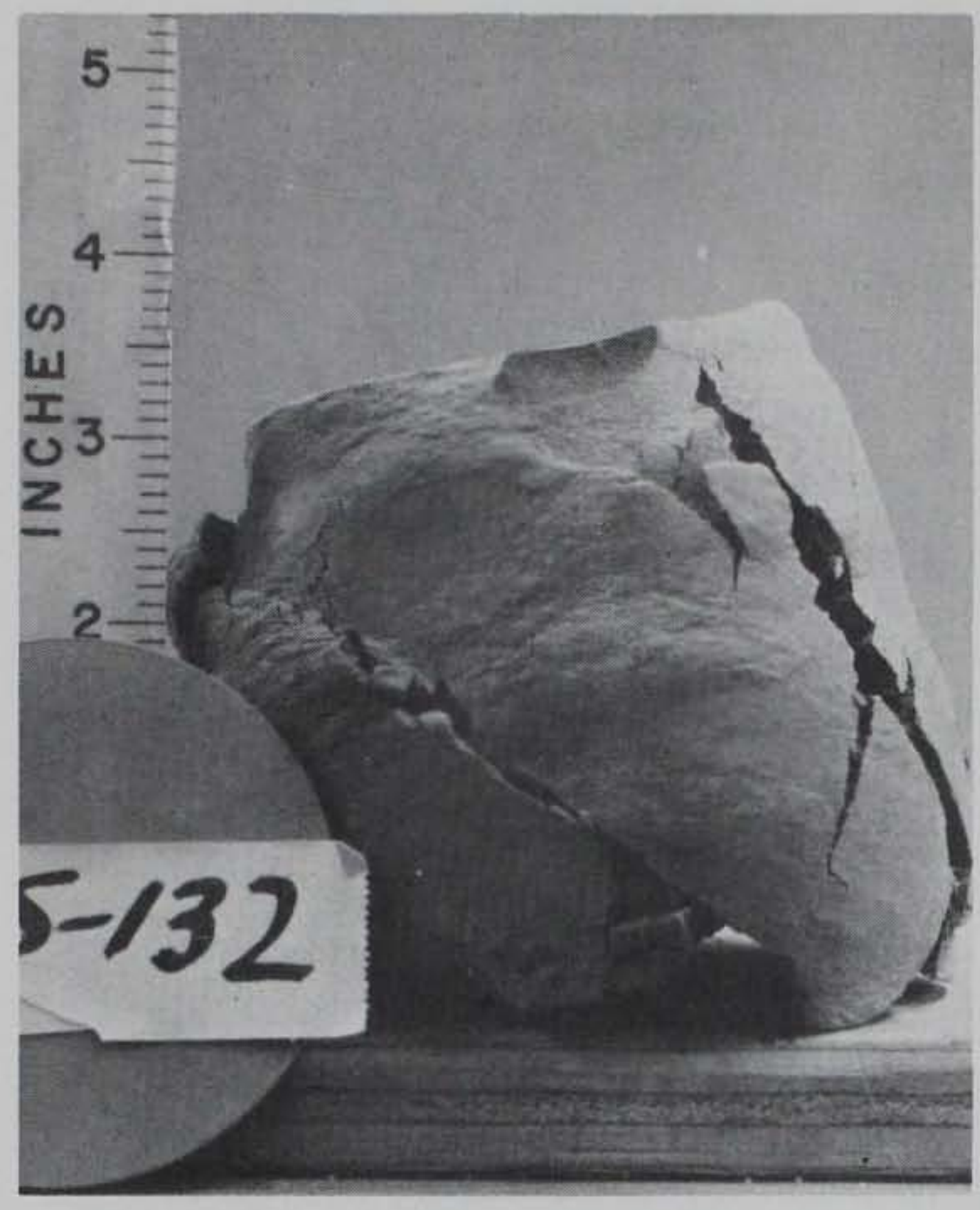

a. Plastic deformation of Hanover silt at $800 \mathrm{psi}(58 \%$ of instantaneous strength), $15^{\circ} \mathrm{F}, e=0.89$.

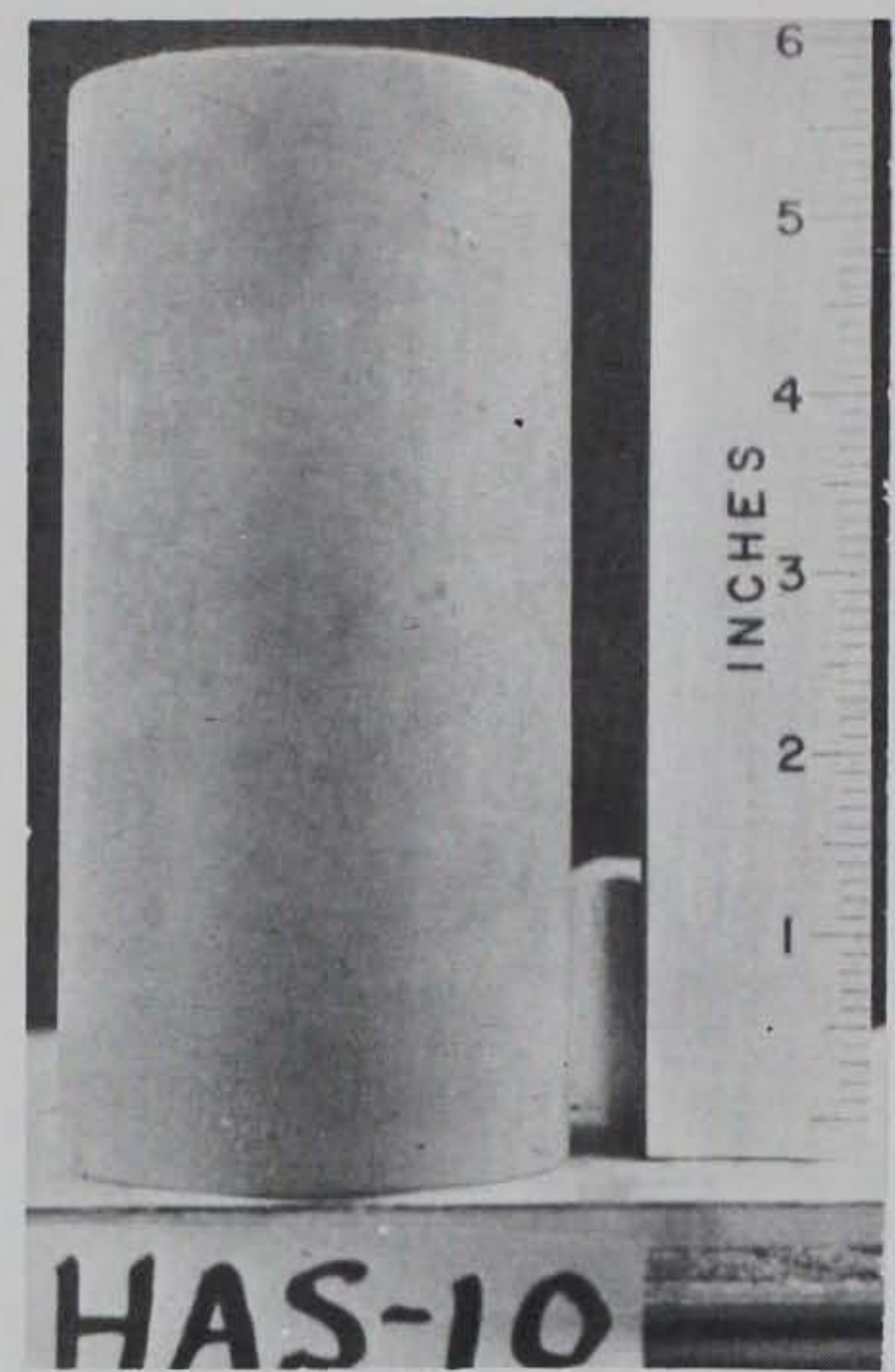

b. Hanover silt specimen subjected to $330 \mathrm{psi}$ ( $24 \%$ of instantaneous strength) for $1050 \mathrm{hr}$ at $15^{\circ} \mathrm{F}, \mathrm{e}=0.89$.

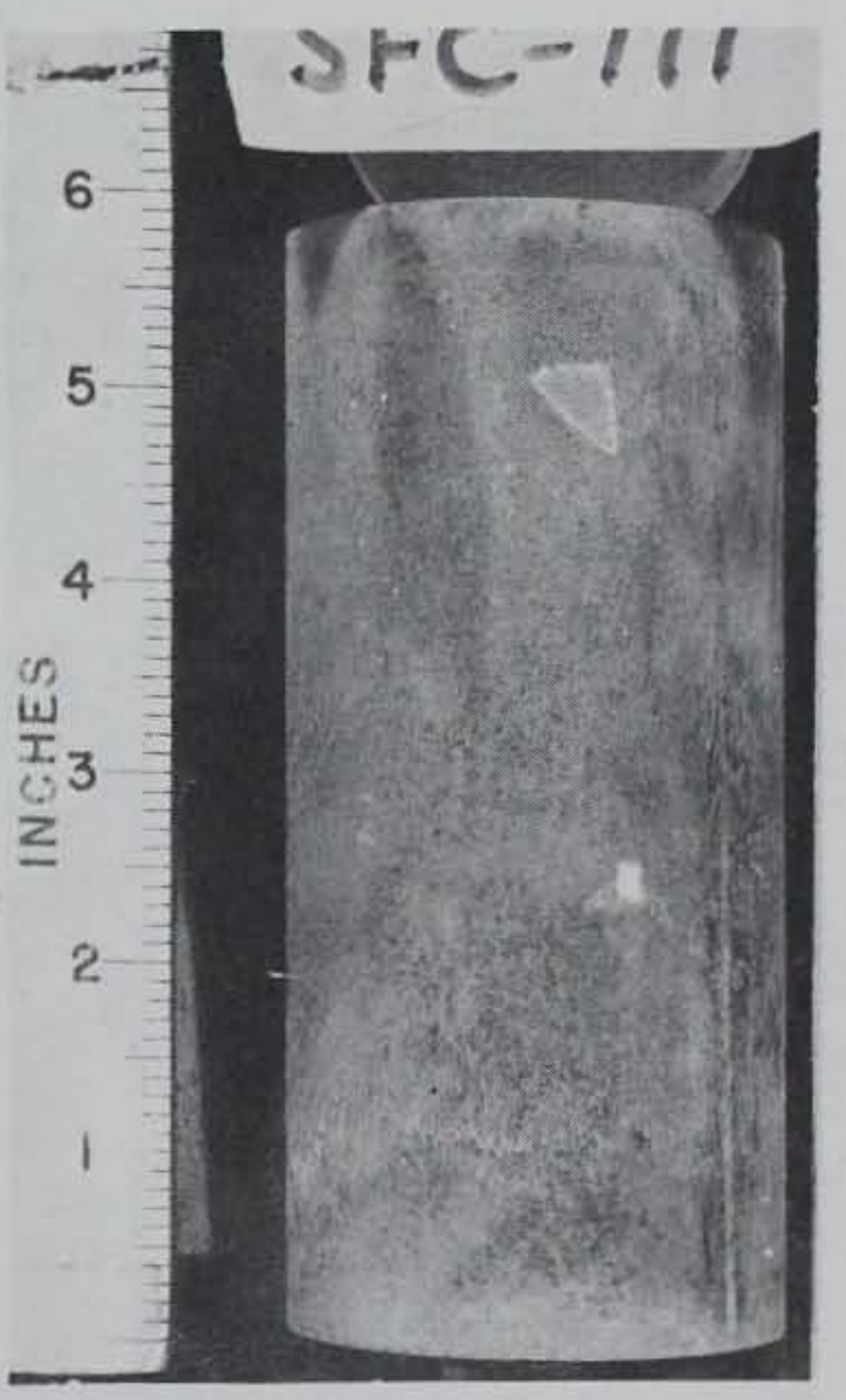

c. Plastic deformation of Suffield clay at $420 \mathrm{psi}$ d. Suffield clay specimen subjected to $140 \mathrm{psi}$ ( $60 \%$ of instantaneous strength), $15^{\circ} \mathrm{F}, e=1.10$. (20\% of instantaneous strength) for $750 \mathrm{hr}$ at $15^{\circ} \mathrm{F}, \mathrm{e}=1.06$.

Figure 16. Typical Hanover silt and Suffield clay specimens after creep testing. 


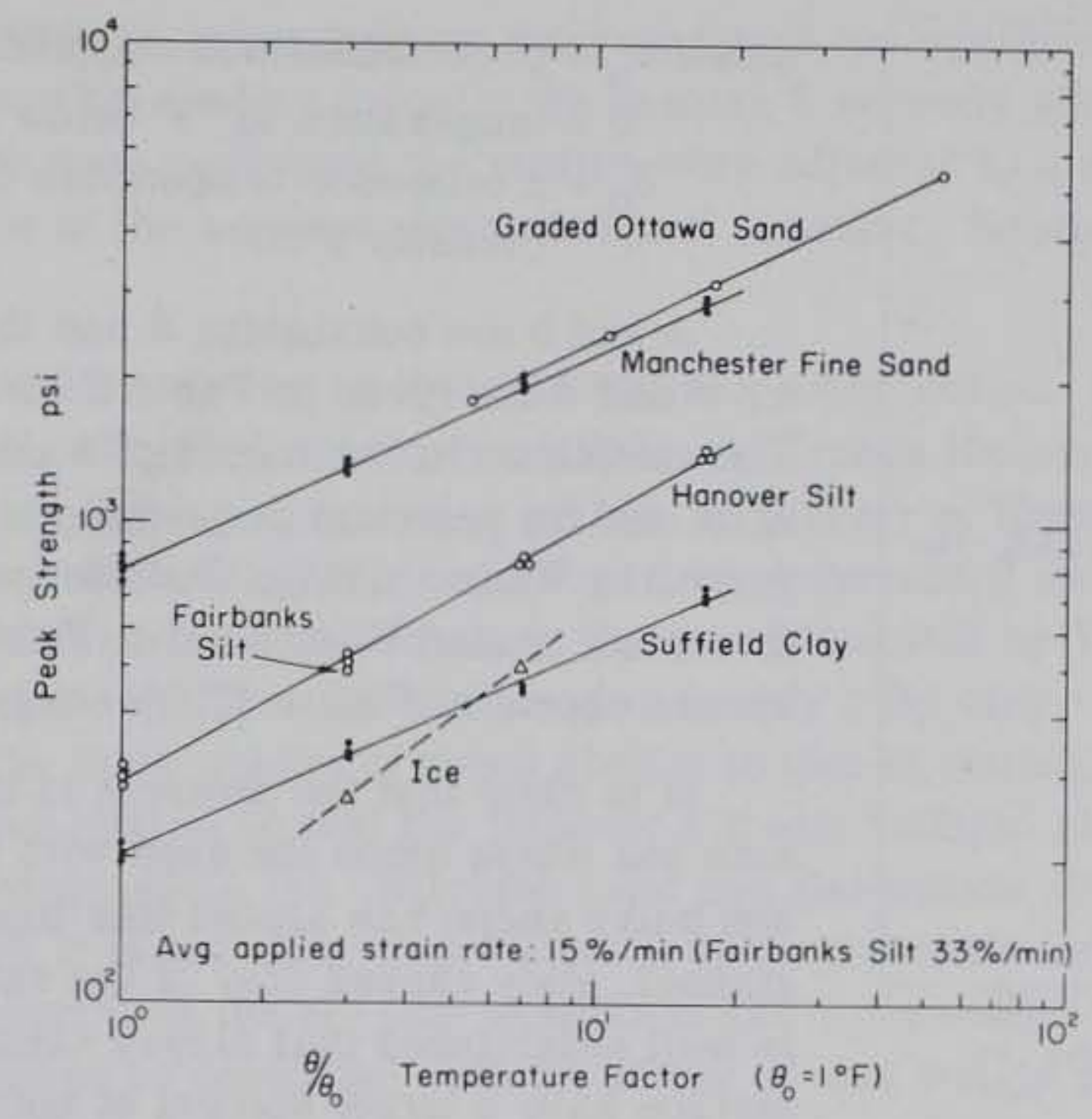

Figure. 17. Peak strength and temperature factor.

\section{DISCUSSION'}

\section{Unconfined compression stress-strain data}

Unconfined compression tests were performed on Hanover silt and Suffield clay at a constant strain rate to establish the conventional or instantaneous compressive strength (maximum stress) of the frozen soils at each test temperature. The resulting stress-strain plots from these tests are summarized in Figures 3 and 4; Table I lists the peak strength, tangent modulus and rate of load for each soil specimen. The true ("logarithmic" or "natural") strains* were computed by subtracting the testing machine compliance from the deformations and adjusting the constant load value to a constant stress basis. A comparison of the curves for the different temperatures clearly shows that the strength increases with decreasing temperature. The frozen silt and clay are highly plastic at the temperature and strain rates of these tests.

It is interesting to note that except at $15^{\circ} \mathrm{F}\left(-9.45^{\circ} \mathrm{C}\right)$ for the Hanover silt, the stress-strain curves for the fine-grained frozen soils could be represented quite well by ideal elastic-plastic stress-strain curves, i.e. by an initial inclined line (elastic) and a horizontal line (plastic) as indicated by the dashed line in Figure 4. The idealized bilinear curve for all these stress-strain curves displays a break point at strains of less than $1 \%$.

A logarithmic plot of a temperature factor vs unconfined compression peak strength of the frozen soils in Figure 17 shows that the increase in strength with decrease in temperature can be approximated by:

$$
\sigma_{\mathrm{p}}=A\left(\frac{\theta}{\theta_{0}}\right)^{b}
$$

\footnotetext{
* True strain $=\ln \left(1 / 1-\epsilon_{\mathrm{c}}\right)$ where the conventional strain $=\epsilon_{\mathrm{c}}=\Delta L / L_{0}=$ axial deformation/original length.
} 


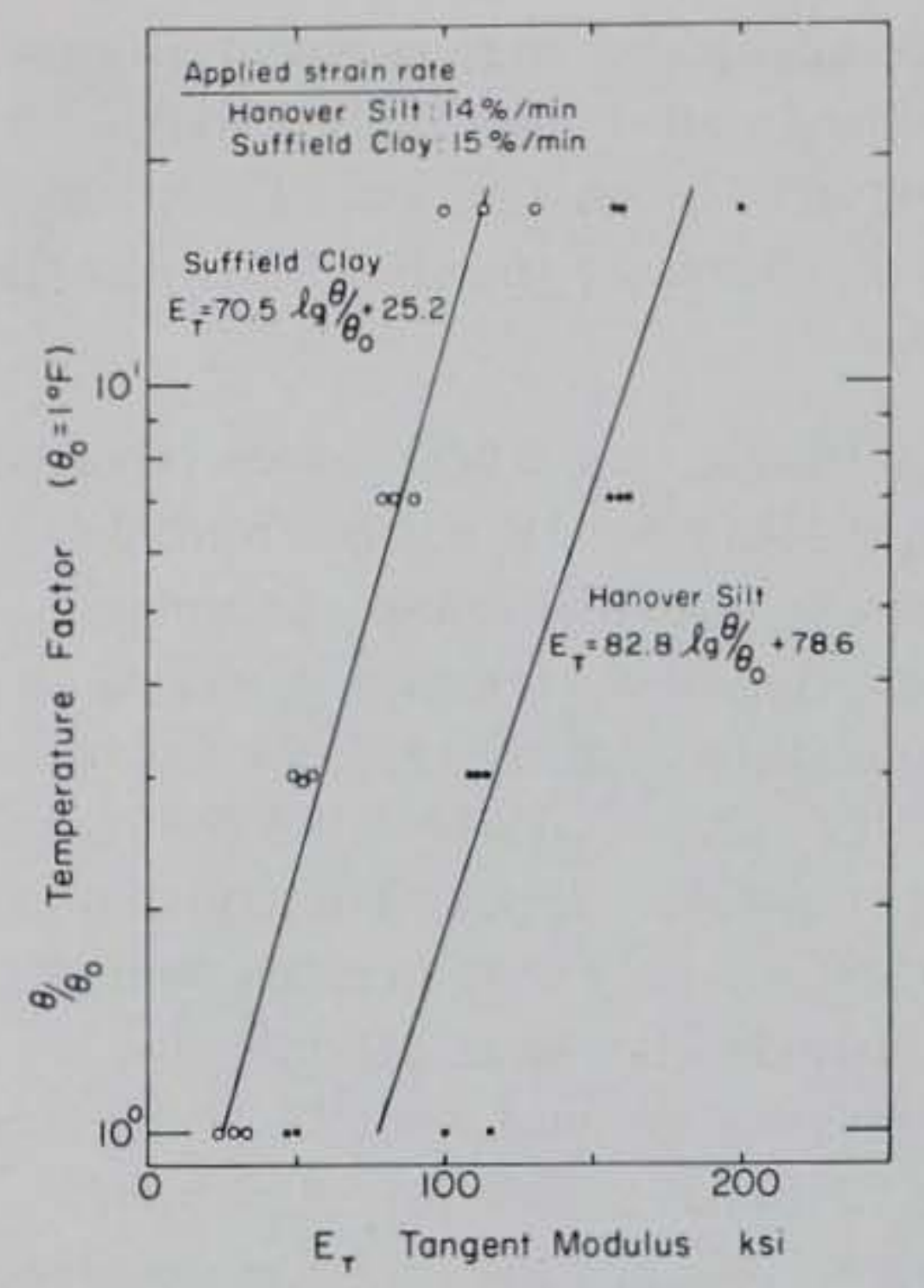

Figure 18. Tangent modulus and temperature. where $\sigma_{\mathrm{p}}=$ peak unconfined compressive strength

$\theta=$ temperature in ${ }^{\circ} \mathrm{F}$ below $32^{\circ} \mathrm{F}$

$\theta_{0}=$ a reference temperature $(\theta)$ greater than zero (usually $1^{\circ} \mathrm{F}$ )

$A$ and $b$ are constants; $A$ has the units of stress. Values for $A$ and $b$ are given in Table II for four different frozen soils. The variations in the values of $b$ are small for the different soils and for practical purposes can be taken as 0.5 as suggested by Vialov (1962). Data for saturated frozen Manchester fine sand, graded Ottawa sand, Fairbanks silt and columnar ice are shown in Figure 17 for comparison.

It is clear that the strength is influenced by the soil grain size and shape since the sand with the larger particle size and bulky shape has almost four times the strength of the finegrained, platy shaped clay of the same temperature. Since it is well established that clayey soils with higher specific surface have a larger percent of unfrozen water by weight than soils with a bulky shape (Anderson and Tice 1972), the greater quantity of unfrozen water in the clay could partly account for its lower strength. The likelihood that the points

of contact between the bulky shaped particles are firmer and more positive than those between platy shaped particles could account for a larger contribution of friction and part of the increased strength of the sands.

The slope of the stress-strain curves (Fig. 3,4) at $50 \%$ maximum stress is designated as the tangent modulus in this report. A plot of the tangent modulus vs the logarithm of the temperature factor $\theta / \theta_{0}$ (Fig. 18) shows that the modulus for both soils increases with decreasing temperature. Equations for straight lines drawn through the data points are shown in Figure 18. Also, to minimize the effect of strain rate on both the peak strength and the tangent modulus, these tests were run at approximately the same strain rates.

Table II. Constants for equation

$$
\sigma_{\mathrm{p}}=A\left(\theta / \theta_{0}\right)^{b} ;\left(\theta_{0}=1^{\circ}\right) \text {. }
$$

\begin{tabular}{llr}
\multicolumn{1}{c}{ Soil } & \multicolumn{1}{c}{$\begin{array}{c}A \\
(p s i)\end{array}$} & \multicolumn{1}{c}{$b$} \\
\hline Graded Ottawa sand & $789\left(5.44 \mathrm{MN} / \mathrm{m}^{2}\right)$ & 0.48 \\
Manchester fine sand & $\frac{812(5.58)}{288(1.92)}$ & 0.44 \\
Hanover silt & $\frac{0.55}{204(1.401)}$ & 0.43 \\
Suffield clay & & $\mathrm{Avg}=0.48$ \\
& & \\
\hline
\end{tabular}

\section{Creep strain-time data}

Creep data presented as deformation vs time curves are the primary results of this investigation and are the basis for the creep analysis that follows. Typical time-deformation curves for Hanover silt and Suffield clay are shown in Figures 6 and 7. The true strains were computed after 
the machine compliance and the instantaneous deformation of the specimens were removed by subtracting the initial deformation reading (usually the reading 5 seconds after load application). Where constant load tests were conducted the strains were adjusted to a constant stress basis by assuming the total volume of the soil specimen remained constant. Summary time-strain curves are shown in Figures 8-15.

In contrast to classical creep curves that characterize many metals, and frozen sands reported by Goughnour and Andersland (1968) and Sayles (1968), the frozen Hanover silt and Suffield clay tested in this investigation displayed extended periods of primary or transient creep. In general tertiary creep was not observed within the accuracy of the deformation measurements at strains less than $20 \%$. This observation is also in contrast to the data presented by Vialov (1963) for frozen Callovian sands (sandy silt - ML) and Bat-baioss clay (sandy silty clay - CL) where the undamped creep curves displayed the three stages of creep similar to that of metals. A possible explanation for this difference in curve shapes is that the Hanover silt and Suffield clay test samples were remolded and artificially frozen while the Callovian sand and Bat-baioss clay were natural, undisturbed soils. Although it is not clear from Vialov's description, the dry unit weights of the soils he tested seem to be greater than the dry unit weights of the soils tested in this investigation. Additional testing is required to determine both the effect of unit weight and the effect of remolding of the soil on the shape of the creep curves.

It is clear from the summary curves in Figures 8-15 that the amount of strain increases with an increase in applied stress and with an increase in the elapsed time after application of stress for each set of tests conducted at a constant temperature. A comparison of the creep curves for the four test temperatures shows that as the temperature increases the strain increases for the same stress condition and time period.

\section{Strain rate}

The strain rates at each point on the observed creep curves were determined by fitting a second degree polynomial to segments of the creep curve where the radius of curvature is small or by fitting a straight line to the segment of the curve where the radius of curvature is large. The rates of strain for each test specimen were computed by fitting the polynomial or the straight line to successive sets of five data points on the strain vs time curve using the method of least squares. The slope of each curve segment was determined at the middle point of the five points. Groups of five data points were considered by advancing along the strain vs time curve one point at a time (i.e. by eliminating the first data point and including a new, advanced data point). The process of fitting the equations and determining the slopes of the curves was repeated for each group of five data points. Using this system, rates of strain were determined for the entire length of the strain vs time curve except for the first two and last two points on the curve.

The strain rate vs time curves in Figures 19 and 20 show the creep rate decreasing continuously, which generally characterizes the creep rate curves of the soils tested in this investigation at strains less than $20 \%$. At strains greater than $20 \%$, a few of the soil specimens showed an increase in strain rate with time, i.e. tertiary creep, and 5 of the 77 Suffield clay specimens displayed a slight increase in strain rate at strains in the range of 14 to $19 \%$. At these large strains the geometry of the specimens and the stress distribution within the soil specimen change to such an extent that meaningful comparison between the observed deformational behaviors at high and low strains would be highly questionable. Therefore, only strains and strain rates without tertiary creep were considered in this investigation. The shapes of the curves in Figures 19 and 20 suggest that creep rate may be represented by a power function of time. 

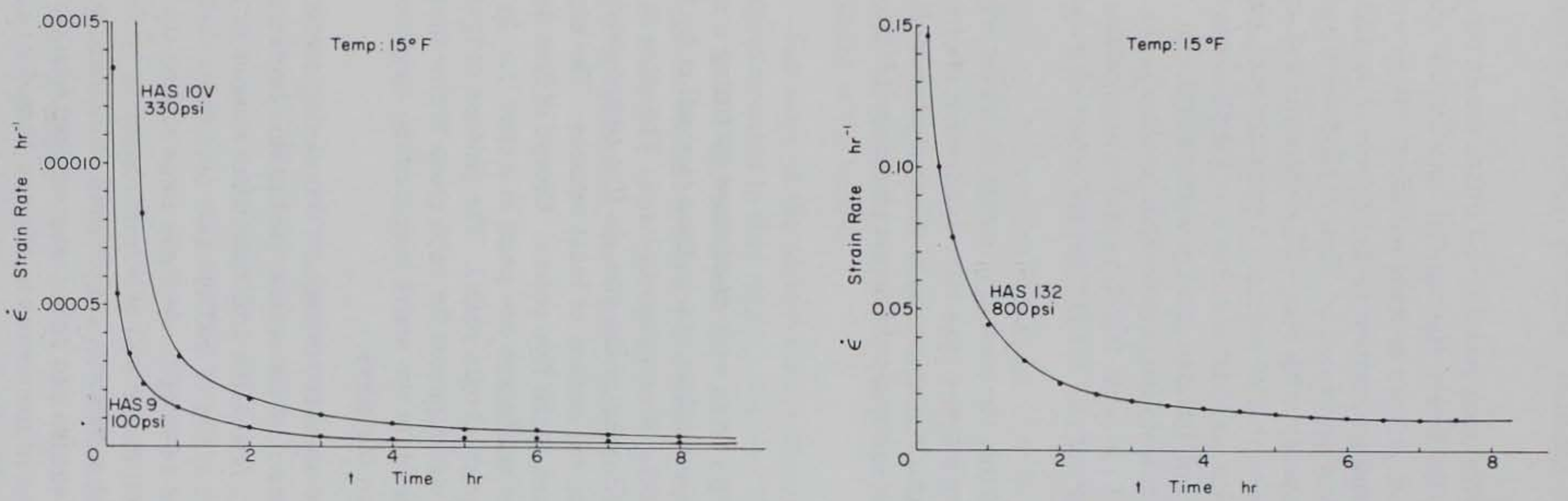

Figure 19. Strain rate vs time, Hanover silt.

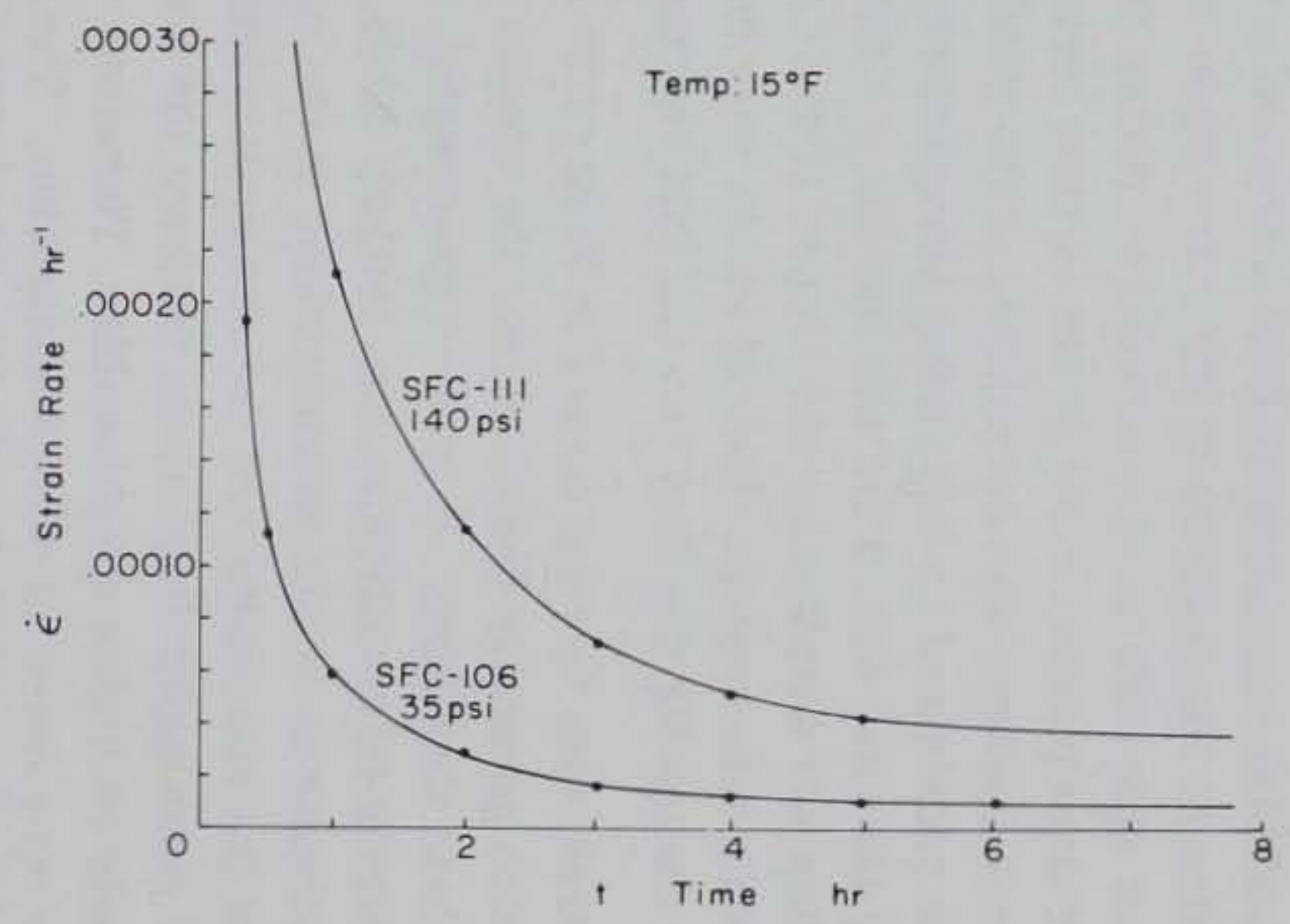

Figure 20. Strain rate vs time, Suffield clay.



Figure 21. Strain rate and reciprocal of time, Hanover silt.

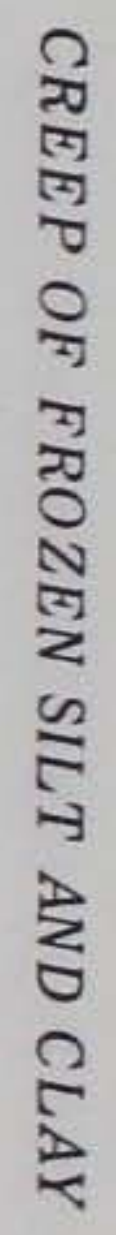




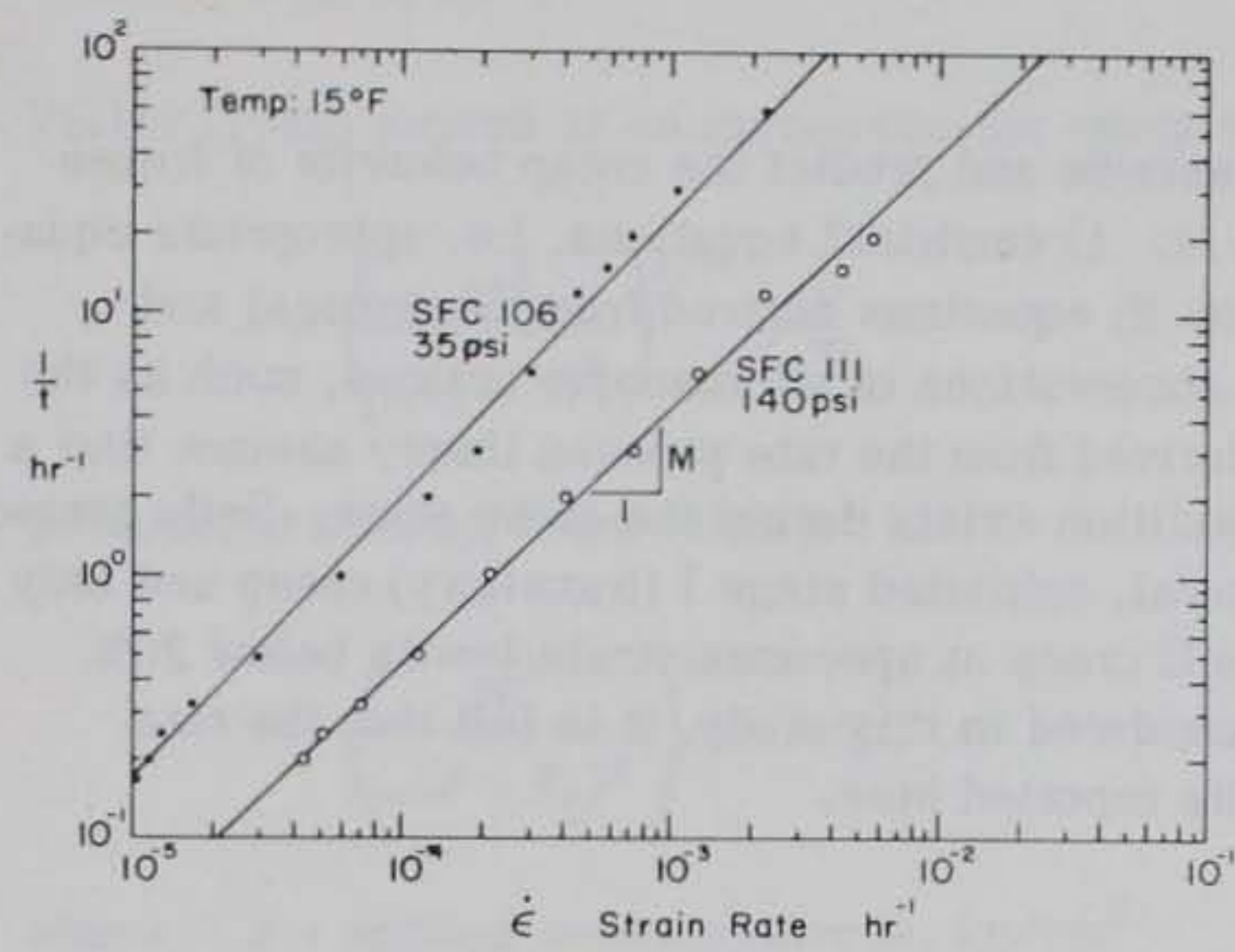

Figure 22. Strain rate and reciprocal of time, Suffield clay.

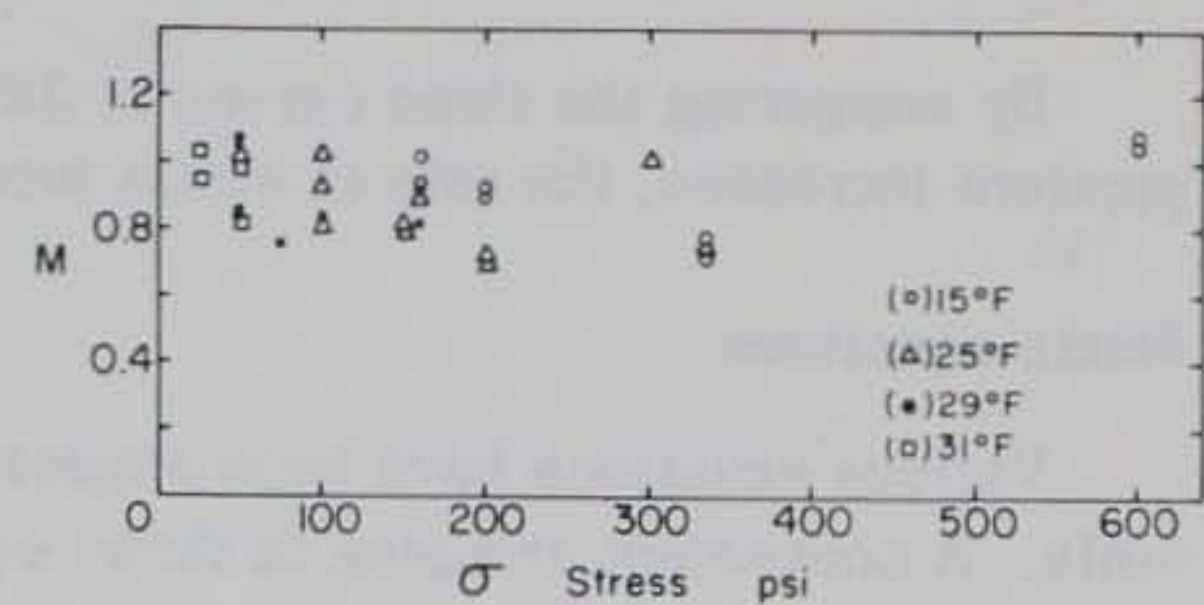

a. Hanover silt.

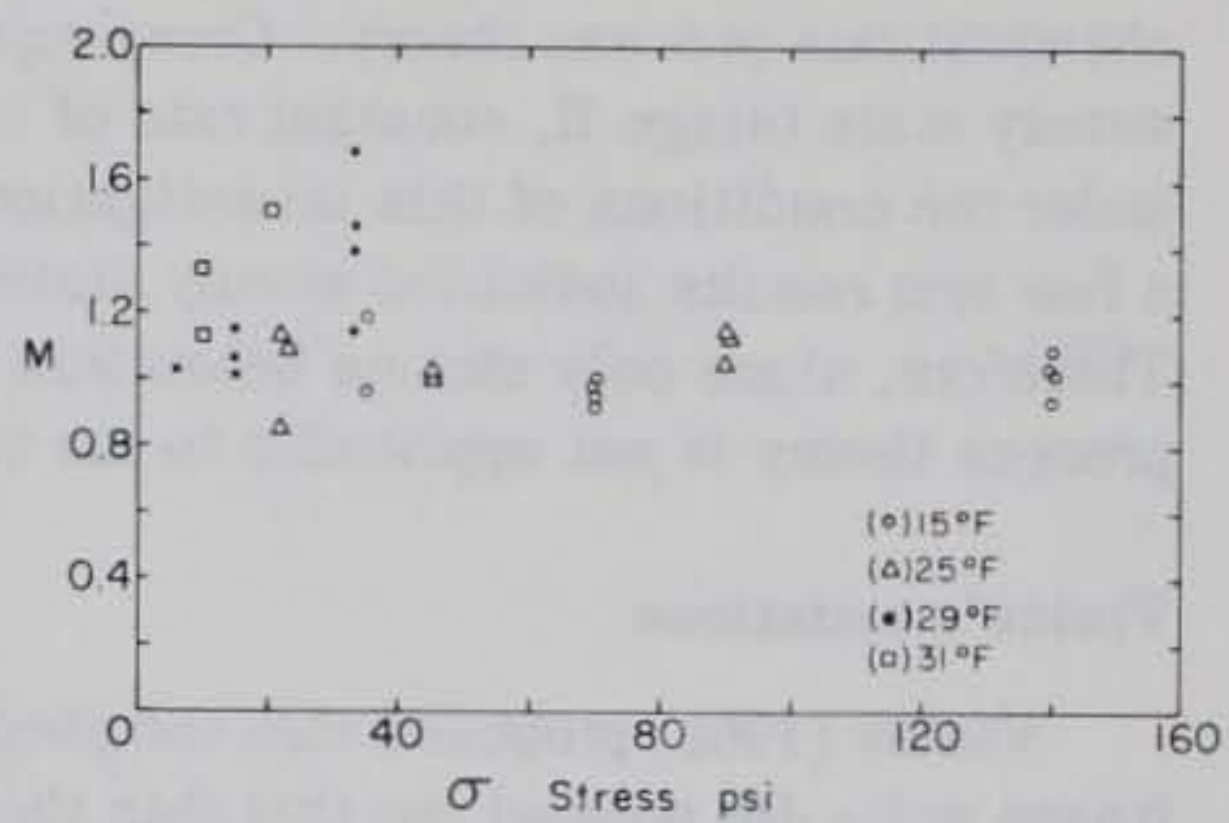

b. Suffield clay.

Figure 23. $M$ and stress.



Figure 24. $M_{\text {avg }}$ vs temperature.



Figure 25. Strain rate and reciprocal of time, Hanover silt.

Typical strain rate vs reciprocal-of-time curves for the different stresses plotted on logarithmic coordinates (Fig. 21, 22) are nearly straight lines. The magnitude of the strain rate clearly increases with stress. Also, the rate of change of the strain rate (i.e. the slope of the curve) appears to be only slightly dependent on stress for most of the temperatures tested. This observation is demonstrated in Figure 23a for Hanover silt, where the slopes of the curves $(M)$ are plotted against stress. Figure 23b indicates that slopes $(M)$ for Suffield clay at $15^{\circ}$ and $25^{\circ} \mathrm{F}$ are nearly independent of stress; however, the limited data for temperatures of $29^{\circ}$ and $31^{\circ} \mathrm{F}$, particularly for the clay, show some dependence on stress even though the scatter of the data is large. This scatter is undoubtedly influenced by the amount of unfrozen water content at temperatures near $32^{\circ} \mathrm{F}$ (Anderson and Tice 1972). Figure 24 indicates that $M$ is dependent only slightly on temperature for both soils. 
By comparing the three curves at different temperatures in Figure 25, it is clear that as temperature increases, the rate of strain increases for the same level of stress.

\section{Strain equations}

Various equations have been suggested to describe and predict the creep behavior of frozen soils. A convenient grouping of these equations is: 1) empirical equations, i.e. appropriate equations fitted to observed experimental creep curves; 2) equations derived from mechanical and mathematical models; and 3) equations based on observations of microscopic actions, such as the chemical rate process theory. Creep equations derived from the rate process theory assume that a steady state (stage II, constant rate of strain) condition exists during the creep tests. Soils tested under the conditions of this investigation, in general, exhibited stage I (transitory) creep and only a few test results indicated steady state or stage II creep at specimen strain levels below $20 \%$. Therefore, since only strains below $20 \%$ were considered in this study, it is felt that the rate process theory is not applicable to the test results reported here.

\section{Vialov's equations}

Vialov (1962) proposed that the theory of hereditary creep be used to describe the creep of frozen soil. He pointed out that this theory is quite flexible and is based on the assumption that deformation at any given time and temperature depends upon both the applied stress and the history of any prior deformation. Prior deformations are included by use of the principle of superposition. The following equation (mathematical model) was used by Vialov (1962) to describe frozen soils he investigated:

$$
\epsilon=\frac{\sigma_{\mathrm{n}}}{E_{0}}+\int_{0}^{t} \sigma_{\mathrm{n}} k\left(t-t_{\mathrm{n}}\right) d t_{\mathrm{n}}
$$

where $\quad \epsilon=$ time-dependent strain

$\sigma_{\mathrm{n}}=$ stress, which may or may not be time-dependent (stress was constant for this investigation)

$t=$ time elapsed

$t_{\mathrm{n}}=$ time at which stress $\sigma_{\mathrm{n}}$ is applied

$E_{0}=$ instantaneous modulus

$k\left(t-t_{\mathrm{n}}\right)=$ a function describing the strain taking place after stress application at time $t_{\mathrm{n}}$.

For constant stress $\sigma_{0}$ and initial time equal to zero $\left(t_{\mathrm{n}}=0\right)$, eq 1 becomes:

$$
\epsilon=\frac{\sigma_{0}}{E_{0}}+\sigma_{0} \int_{0}^{t} k(t) d t .
$$

The first term on the right-hand side of the equation represents the instantaneous strain caused by the stress $\left(\sigma_{\mathrm{n}}=\sigma_{0}\right)$ and the second term represents the increase in strain with time produced by stress $\left(\sigma_{0}\right)$.

Using the time hardening relationship between stress, strain and time (Vialov 1959):

$$
f(\sigma, t, \epsilon)=0
$$


and the power function for strain:

$$
\sigma=f(t, \theta) \epsilon^{m} .
$$

Vialov (1962) arrived at an expression for creep strain:

$$
\epsilon=\left(\frac{\sigma t^{\lambda}}{\omega(\theta+1)^{k}}\right)^{1 / m}+\epsilon_{0}
$$

or as suggested by Assur (1963):

$$
\epsilon=\left(\frac{o^{\lambda}}{\omega\left(\theta+\theta_{0}\right)^{k}}\right)^{1 / m}+\epsilon_{0}
$$

where $\quad \sigma=$ applied constant stress, $\mathrm{kg} / \mathrm{cm}^{2}$

$t=$ time elapsed after application of load $(\mathrm{hr})$

$\theta=$ temperature below the freezing point of water, ${ }^{\circ} \mathrm{C}$

$\theta_{0}=$ constant reference temperature greater than zero, ${ }^{\circ} \mathrm{C}$ (Vialov assumed $1^{\circ} \mathrm{C}$ )

$\epsilon_{0}=$ instantaneous strain

$\lambda, m, \omega, k=$ constants that are characteristic of the material (and $\omega$ depends on units).

Since the first term on the right-hand side of eq 4 was developed from the power function, $\sigma=f(t, \theta) \epsilon^{m}$, it can be rewritten as:

$$
\sigma=A \epsilon^{m}
$$

where $A=f(t, \theta)$ in units of stress. Values of $A$ and $m$ are obtained from log plots of stress against strain for various time intervals after application of stress to the test specimens (see Fig. 26). The data can be represented by straight lines even though there is considerable scatter. Average slopes of these lines for different temperatures are shown in Table III. These slopes $(m)$ may be considered characteristic of the frozen soils that were tested.

Table III. Value of $m$ in Vialov's strain equation.

\begin{tabular}{ccc} 
Temp & $\begin{array}{c}\text { Hanover } \\
\text { silt }\end{array}$ & $\begin{array}{c}\text { Suffield } \\
\text { clay }\end{array}$ \\
\hline $\begin{array}{c}15^{\circ} \mathrm{F} \\
\left(-9.45^{\circ} \mathrm{C}\right)\end{array}$ & 0.47 & 0.44 \\
$\begin{array}{c}25 \\
(-3.89)\end{array}$ & 0.45 & 0.40 \\
$\begin{array}{c}29 \\
(-1.67)\end{array}$ & 0.51 & 0.41 \\
$\begin{array}{c}31 \\
(-0.556)\end{array}$ & 0.53 & 0.41 \\
Avg & $\overline{0.49}$ & $\overline{0.42}$ \\
\hline
\end{tabular}




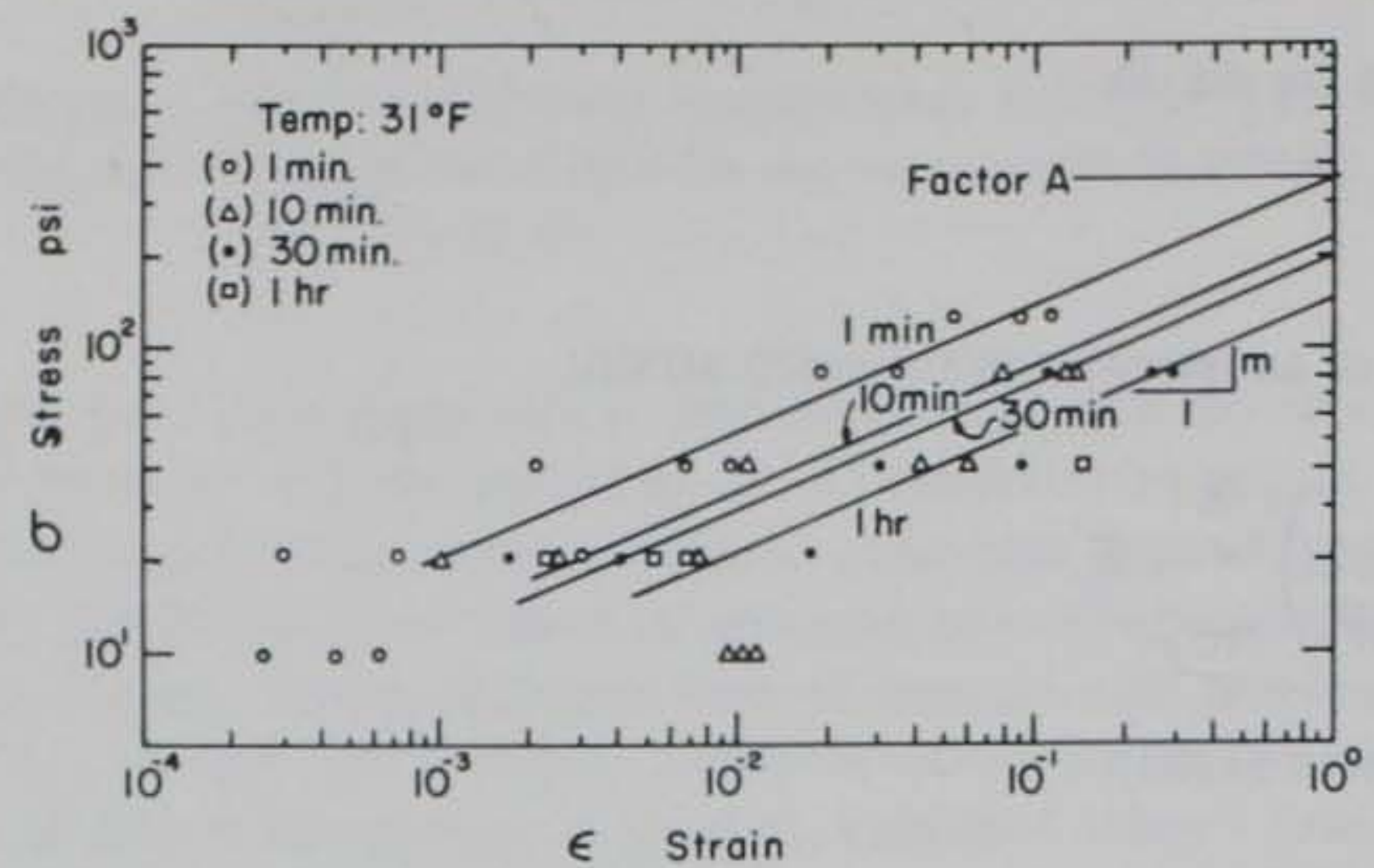

Figure 26. Stress, strain and time, Suffield clay, $31^{\circ} \mathrm{F}, \sigma=A \epsilon^{\mathrm{m}}$.



Figure 27. Time, factor $A$, and temperature.

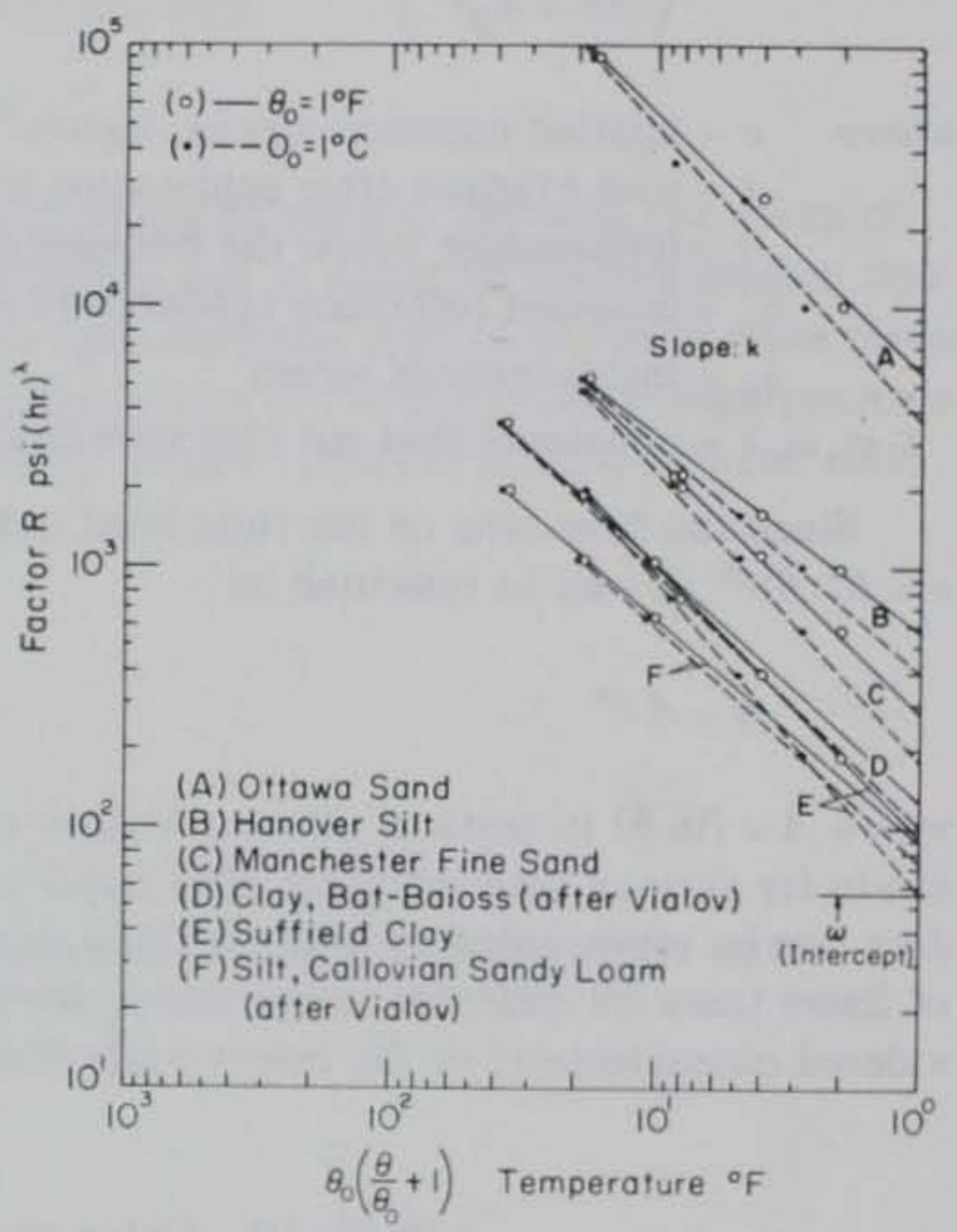

Figure 28. Factor $R$ and temperature.

Following Vialov's procedure for determining the time and temperature functions in eq 5 , the values of factor $A$ (i.e. the ordinate for $\log$ strain equal to unity) from Figure 26 are plotted against the corresponding time for the different test temperatures in Figure 27. Values for $R$ and the exponent $\lambda$ for the equation for the straight lines, $A=R t^{\lambda}$ were obtained as indicated in Figure 27. The constants $\omega$ and $k$ are similarly obtained by plotting the intercept $R$ (at time $=1 \mathrm{hr}$ ) against $\theta_{0}\left(\theta / \theta_{0}+1\right)$ as shown in Figure 28. The constants obtained for Hanover silt and Suffield clay are listed together with those for Callovian sandy loam (sandy silt - ML) and Bat-baioss clay (clay CL) by Vialov (1962) in Table IV. Values for Ottawa sand and Manchester fine sand (Sayles 1968) are included in the table also.

A comparison is made between the plot of Vialov's equation (eq 4) and test data for Hanover silt and Suffield clay in Figure 29. Since the constants in this equation were determined for the average of several tests at different stress levels and temperatures, it is not surprising that the equation does not fit all the data curves more closely. 

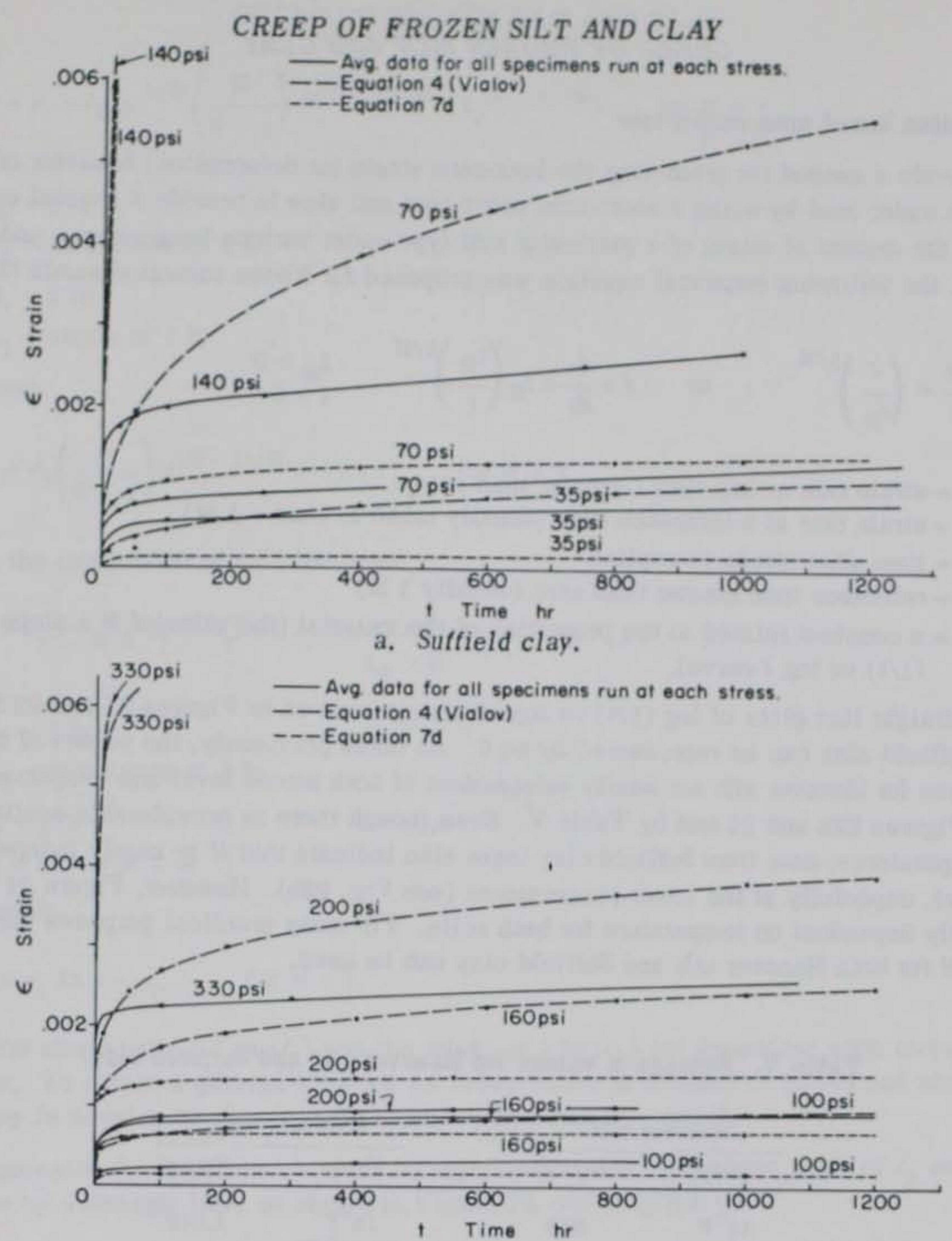

b. Hanover silt.

Figure 29. Strain vs time, comparative curves, $15^{\circ} \mathrm{F}$.

Table IV. Constants for Vialov's strain equation.

\begin{tabular}{|c|c|c|c|c|c|c|}
\hline Material & $m$ & $\lambda$ & $\begin{array}{l}\frac{\omega}{F o r} \theta_{0}=1^{\circ} F \\
[p s i(h r) \lambda]]^{\circ} F\end{array}$ & $k$ & $\begin{array}{c}\omega \\
\text { For } \theta_{0}=1^{\circ} \mathrm{C} \\
{[p s i(h r) \mu]}\end{array}$ & $k$ \\
\hline Suffield clay & 0.42 & 0.14 & 93.0 & 1.0 & $53(7.5)^{*}$ & 1.2 \\
\hline Bat-baioss clay ${ }^{\dagger}$ & 0.40 & 0.18 & 130.0 & 0.97 & $103(12.8)$ & 0.97 \\
\hline Hanover silt & 0.49 & 0.074 & 570.0 & 0.76 & $400(46.7)$ & 0.87 \\
\hline Callovian sandy loamt & 0.27 & 0.10 & 90.0 & 0.89 & $76(9.0)$ & 0.89 \\
\hline $\begin{array}{l}\text { Otta wa sand ** } \\
\text { (20-30 mesh) }\end{array}$ & 0.78 & 0.35 & 5500.0 & 0.97 & $3600(456)$ & 1.0 \\
\hline $\begin{array}{l}\text { Manchester fine sand** } \\
(40-200 \text { mesh })\end{array}$ & 0.38 & 0.24 & 285. & 0.97 & $185(23.4)$ & 1.0 \\
\hline
\end{tabular}

- $\omega$ in $\mathrm{kg} / \mathrm{cm}^{2}(\mathrm{hr}) \lambda /{ }^{\circ} \mathrm{C}^{k}$ shown in parentheses.

$\dagger$ Data from Vialov et al. (1963), Chapter V.

* Data from Sayles (1968). 


\section{Strain equation based upon strain rate}

To provide a method for predicting the long-term strain (or deformation) behavior of a frozen soil sample under load by using a short-term creep test and also to provide a general equation for estimating the amount of strain of a particular soil type under various temperatures and stress conditions, the following empirical equation was proposed for frozen saturated sands (Sayles 1968):

$$
\frac{t_{\mathrm{R}}}{t}=\left(\frac{\dot{\epsilon}}{\epsilon_{\mathrm{R}}}\right)^{1 / M} \quad \text { or } \quad \dot{\epsilon}=\frac{d \epsilon}{d t}=\dot{\epsilon}_{\mathrm{R}}\left(\frac{t_{\mathrm{R}}}{t}\right)^{1 / M} \quad t_{\mathrm{R}}>0
$$

where $\quad \dot{\epsilon}=$ strain rate at any time $t$ greater than zero

$\dot{\epsilon}_{\mathrm{R}}=$ strain rate at a reference time (usually taken at time $=1 \mathrm{hr}$ )

$t=$ time after stress is applied

$t_{\mathrm{R}}=$ reference time greater than zero (usually $1 \mathrm{hr}$ )

$M=$ a constant related to the properties of the material (the value of $M=$ slope of $\log$ $(1 / t)$ vs $\log \dot{\epsilon}$ curve).

The straight line plots of $\log (1 / t)$ vs $\log$ strain rate curves in Figures 21 and 22 for Hanover silt and Suffield clay can be represented by eq 6 . As noted previously, the values of the slope $M$ of the curves for Hanover silt are nearly independent of both stress level and temperature as indicated by Figures 23a and 24 and by Table V. Even though there is considerable scatter at the higher temperatures, data from Suffield clay tests also indicate that $M$ is nearly independent of stress level, especially at the lower temperatures (see Fig. 23b). However, Figure 24 reveals that $M$ is slightly dependent on temperature for both soils. For many practical purposes the average values of $M$ for both Hanover silt and Suffield clay can be used.

Table V. Average $M$ values for Hanover silt and Suffield clay.

\begin{tabular}{|c|c|c|c|}
\hline \multicolumn{2}{|c|}{ Hanover silt } & \multicolumn{2}{|c|}{ Suffield clay } \\
\hline Temp & $M(a v g)$ & Temp & $M(a v g)$ \\
\hline $\begin{array}{c}15^{\circ} \mathrm{F} \\
\left(-9.45^{\circ} \mathrm{C}\right)\end{array}$ & .923 & $\begin{array}{c}15^{\circ} \mathrm{F} \\
\left(-9.45^{\circ} \mathrm{C}\right)\end{array}$ & 1.012 \\
\hline $\begin{array}{c}25 \\
(-3.89)\end{array}$ & .860 & $\begin{array}{c}25 \\
(-3.89)\end{array}$ & 1.054 \\
\hline $\begin{array}{c}29 \\
(-1.67)\end{array}$ & .870 & $\begin{array}{c}29 \\
(-1.67)\end{array}$ & 1.231 \\
\hline $\begin{array}{c}31 \\
(-0.556)\end{array}$ & .945 & $\begin{array}{c}31 \\
(-0.556)\end{array}$ & 1.327 \\
\hline \multicolumn{2}{|c|}{$\begin{array}{l}\text { Avg } M \text { for } 32 \text { Hanover } \\
\text { silt samples at all } 4 \\
\text { temperatures }=.889\end{array}$} & \multicolumn{2}{|c|}{$\begin{array}{l}\text { Avg } M \text { for } 30 \text { Suffield } \\
\text { clay samples at all } 4 \\
\text { temperatures }=1.120 \text {. }\end{array}$} \\
\hline
\end{tabular}

To obtain an equation for strain, eq 6 is integrated to give:

$$
\int_{\epsilon_{\mathrm{r}}}^{\epsilon} d \epsilon=\dot{\epsilon}_{\mathrm{R}} t_{\mathrm{R}}{ }^{1 / M} \int_{t_{\mathrm{r}}}^{t} t^{-1 / M} d t \quad \text { for }{ }_{t>0}^{t_{\mathrm{R}}>0}
$$




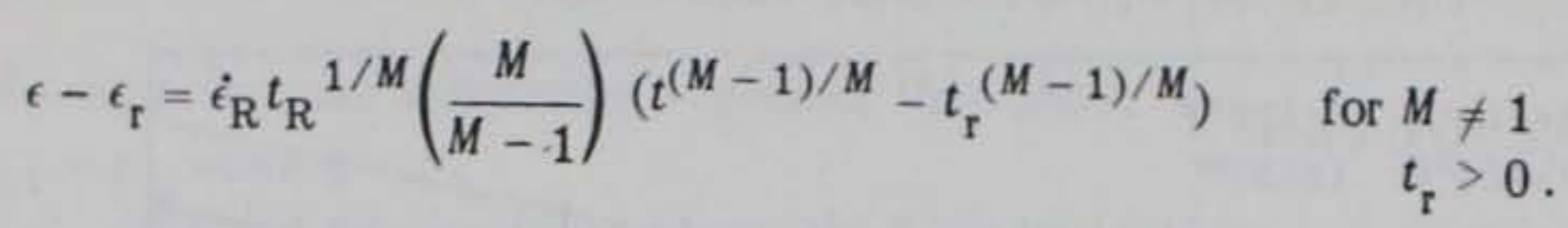

For: $\quad t_{\mathrm{R}}=1 \mathrm{hr}$

$\dot{\epsilon}_{\mathrm{R}}=\dot{\epsilon}_{1}=$ strain rate at $1 \mathrm{hr}$

and for: $t_{\mathrm{r}}=1 \mathrm{hr}$

$\epsilon_{\mathrm{r}}=\epsilon_{1}=$ strain at $1 \mathrm{hr}$

eq 7 becomes:

$$
\epsilon=\dot{\epsilon}_{1}\left(\frac{M}{M-1}\right)\left(t^{(M-1) / M}-1\right)+\epsilon_{1} \quad \text { for } M \neq 1 .
$$

For $M=1$, the integration of eq 6 becomes:

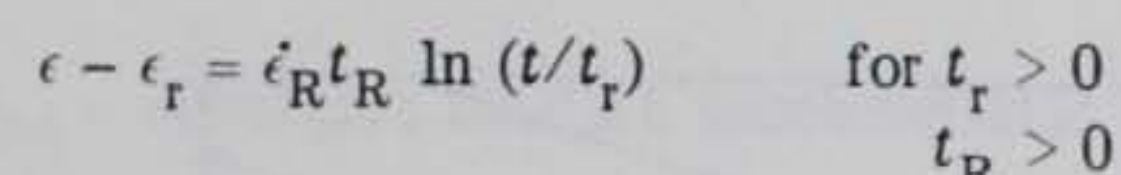

For: $\quad t_{\mathrm{R}}=1 \mathrm{hr}$

$$
\dot{\epsilon}_{\mathrm{R}}=\dot{\epsilon}_{1}=\text { strain rate at } 1 \mathrm{hr}
$$

and for: $t_{\mathrm{r}}=1 \mathrm{hr}$

$$
\epsilon_{\mathrm{r}}=\epsilon_{1}=\text { strain at } 1 \mathrm{hr}
$$

eq $7 \mathrm{~b}$ becomes:

$$
\epsilon=\dot{\epsilon}_{1} \ln t+\epsilon_{1} \quad \text { for } M=1 .
$$

Both the strain rate at $1 \mathrm{hr}\left(\dot{\epsilon}_{1}\right)$ and the strain at $1 \mathrm{hr}\left(\epsilon_{1}\right)$ are dependent upon stress and temperature. To obtain a general equation for creep strain in relation to stress and temperature, it is necessary to develop expressions for $\epsilon_{1}$ and $\epsilon_{1}$ in terms of $\sigma$ and $\theta$.

An expression for $\dot{\epsilon}_{1}$ can be obtained by representing the logarithmic plots of $\dot{\epsilon}_{1}$ vs $\sigma$ for each temperature by a straight line, as shown in Figure 30, and is given by:

$$
\begin{aligned}
& \sigma=\sigma_{1} \dot{\epsilon}_{1}^{k} \\
& \dot{\epsilon}_{1}=\left(\frac{\sigma}{\sigma_{1}}\right)^{1 / k}
\end{aligned}
$$

where: $\quad \sigma_{1}=$ stress at which $\dot{\epsilon}_{1}$ is unity

$k=$ slope of the straight line plot.

In this equation $\sigma_{1}$ is temperature dependent, and $k$ is constant for each material and for the temperature range investigated.

Temperature below freezing $\theta$ is plotted against $\sigma_{1}$ on logarithmic coordinates in Figure 31 . The equation for these curves is:

$$
\sigma_{1}=\sigma_{01}\left(\frac{\theta}{\theta_{1}}\right)^{a}
$$




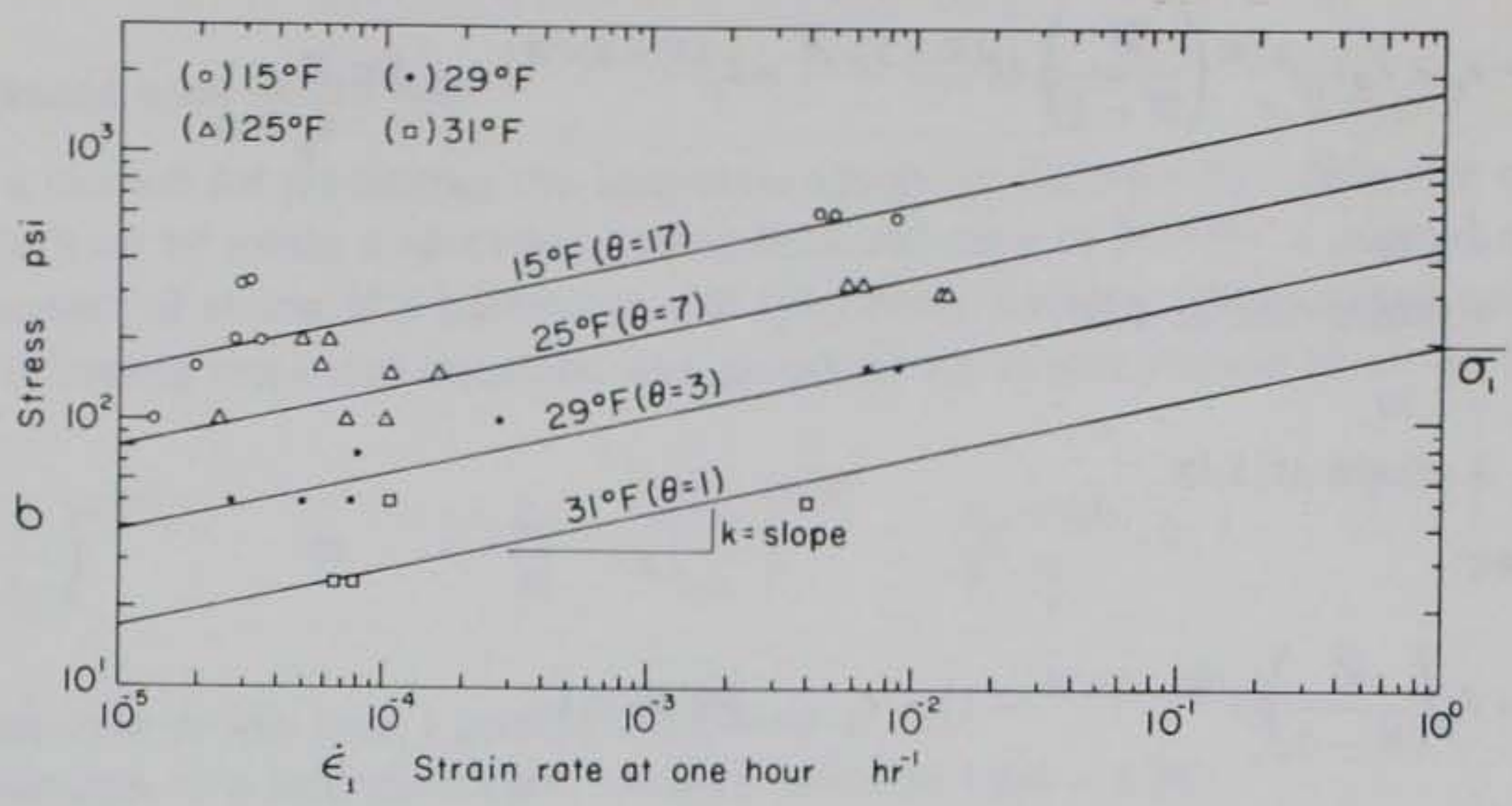

a. Hanover silt.



b. Suffield clay.

Figure 30. Strain rate at one hour and stress.

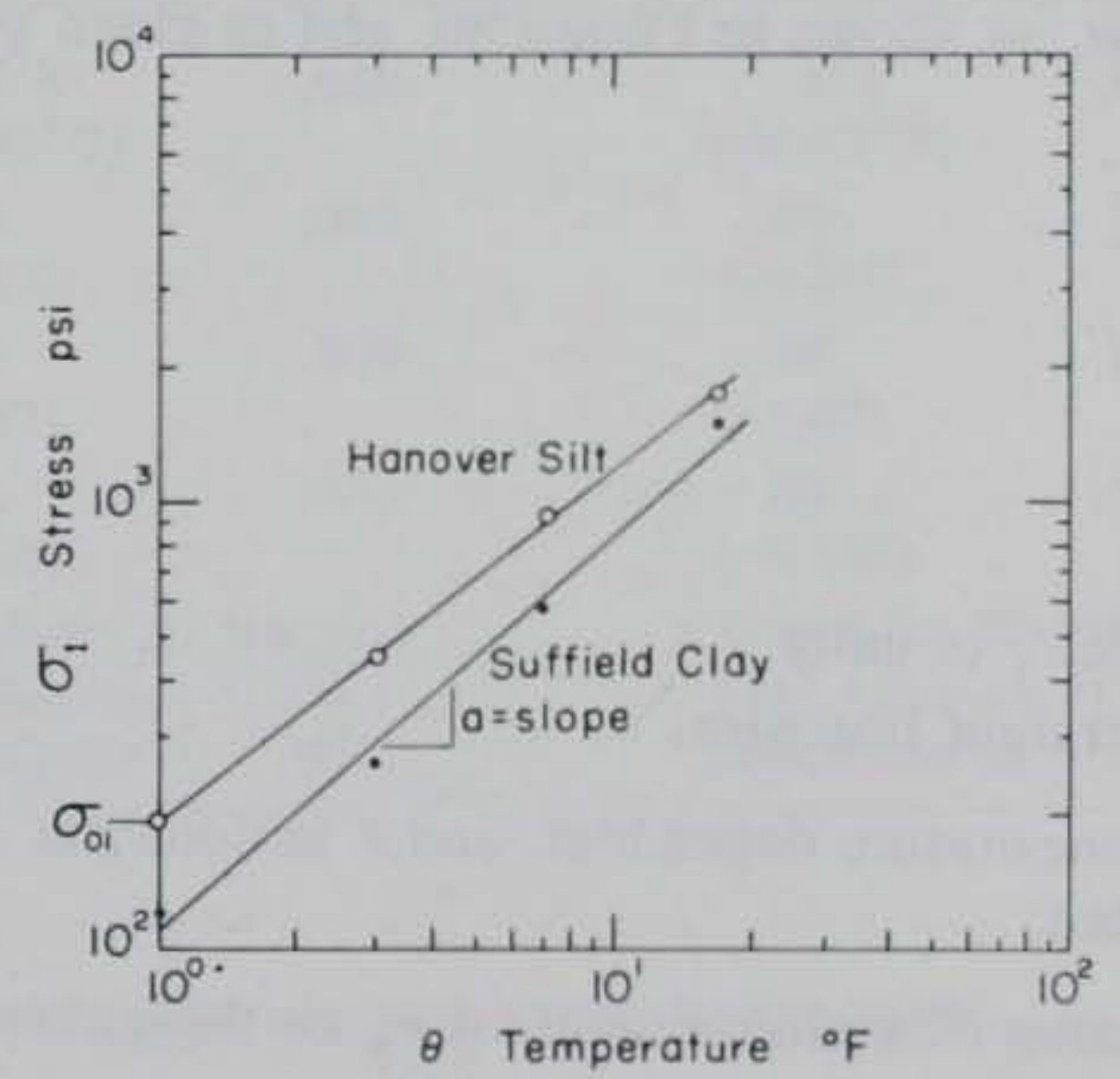

Figure 31. Temperature and stress for unit strain rate at one hour. 
where: $\theta_{1}=\mathrm{a}$ reference temperature (greater than zero)

$\sigma_{01}=\sigma_{1}$ when $\theta=\theta_{1}$

$a=$ slope of the straight line on the logarithmic plot.

Substituting $\sigma_{1}$ from eq 9 into eq 8 , the strain rate for $1 \mathrm{hr}$ becomes:

$$
\dot{\epsilon}_{1}=\left(\frac{\sigma}{\sigma_{1}}\right)^{1 / k}=\left(\frac{\sigma}{\sigma_{01}\left(\theta / \theta_{1}\right)^{a}}\right)^{1 / k}
$$

for: $\quad \theta_{1}=1^{\circ}$

$$
\dot{\epsilon}_{1}=\left(\frac{\sigma}{\sigma_{01} \theta^{a}}\right)^{1 / k}
$$

$\alpha$ and $\sigma_{01}=$ constants that are characteristic of the material ( $\sigma_{01}$ has units of stress).

Similarly, an equation for $\epsilon_{1}$ (strain at $1 \mathrm{hr}$ ) can be developed using Figures 32 and 33:

$$
\epsilon_{1}=\left(\frac{\sigma}{\sigma_{11} \theta^{d}}\right)^{1 / b}
$$

where: $\quad b, d$ and $\sigma_{11}=$ constants that are characteristics of the material ( $\sigma_{11}$ has the units of stress).

Substituting eq $8 \mathrm{~b}$ and $9 \mathrm{a}$ into eq $7 \mathrm{a}$ and $7 \mathrm{c}$ yields:

$$
\epsilon=\left(\frac{M}{M-1}\right)\left(\frac{\sigma}{\sigma_{01} \theta^{\alpha}}\right)^{1 / k}\left(t^{M-1 / M}-1\right)+\left(\frac{\sigma}{\sigma_{11} \theta^{d}}\right)^{1 / b} \quad \text { for } M \neq 1
$$

and

$$
\epsilon=\left(\frac{\sigma}{\sigma_{01} \theta^{a}}\right)^{1 / k} \ln t+\left(\frac{\sigma}{\sigma_{11} \theta^{d}}\right)^{1 / b} \quad \text { for } M=1
$$

Equation 7d and Vialov's equation are compared with average test data curves in Figure 29. The instantaneous strains are neglected in this comparison. Both equations show a poor fit for the higher stress levels. However, at the lower stresses both curves give a reasonable estimate of the strain. Equation 7d gives the better fit although it is unconservative for the lowest stress for the times shown.

Typical values for the constants in eq 7d and 7e are listed in Table VI.

It is important to note that the constants used in Vialov's equation (see Table IV) and those used in eq 7d are based on average values from tests conducted at several temperatures and stress levels. It would be surprising indeed if these equations were to fit all creep curves produced under the various test conditions. Even though the soil samples were prepared and tested under closely controlled conditions, the possibility of variation in density within each test specimen as well as variation in soil structure or fabric between test specimens cannot be precluded. It is, therefore, 


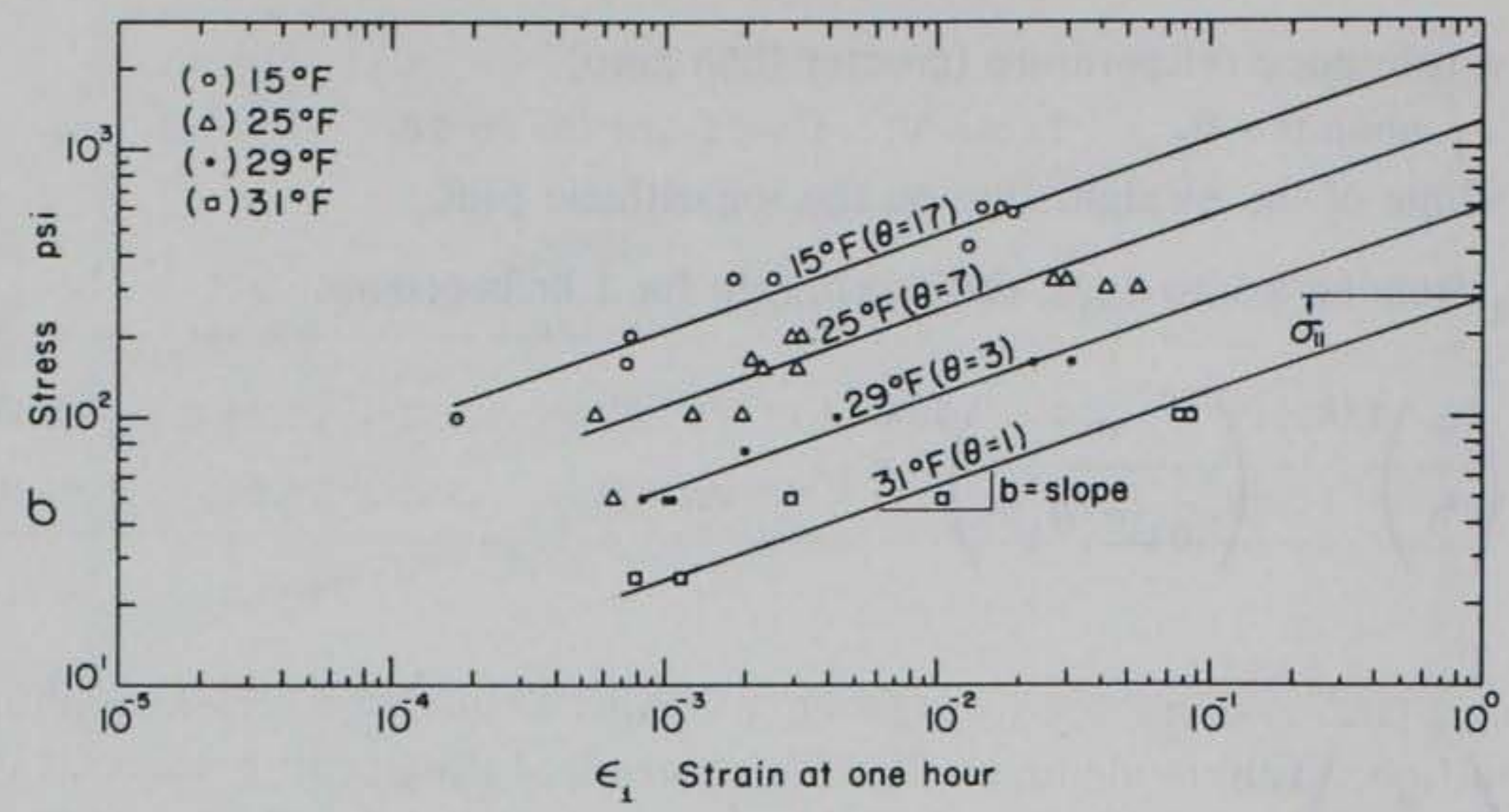

a. Hanover silt.

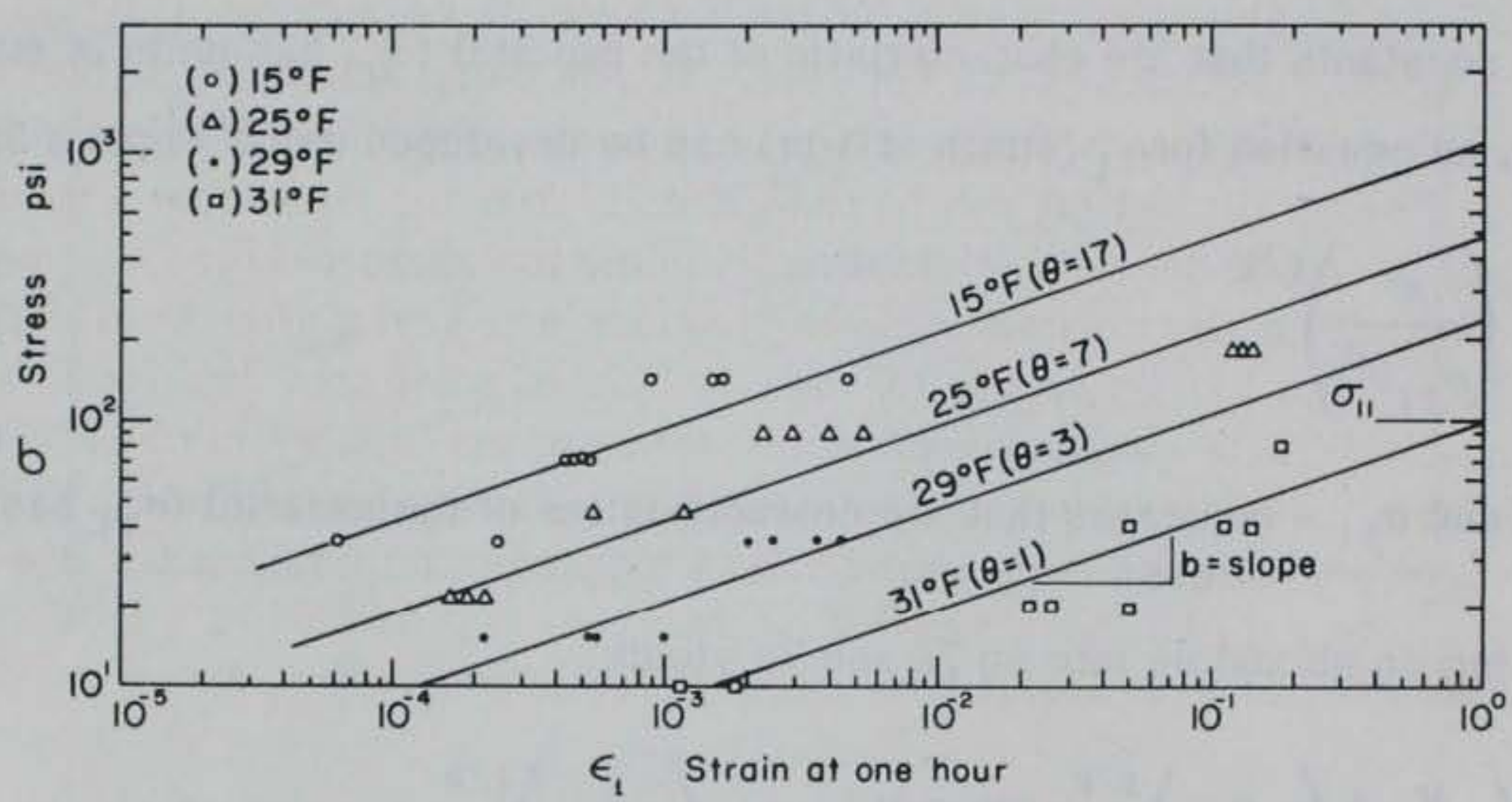

b. Suffield clay.

Figure 32. Strain at one hour and stress.

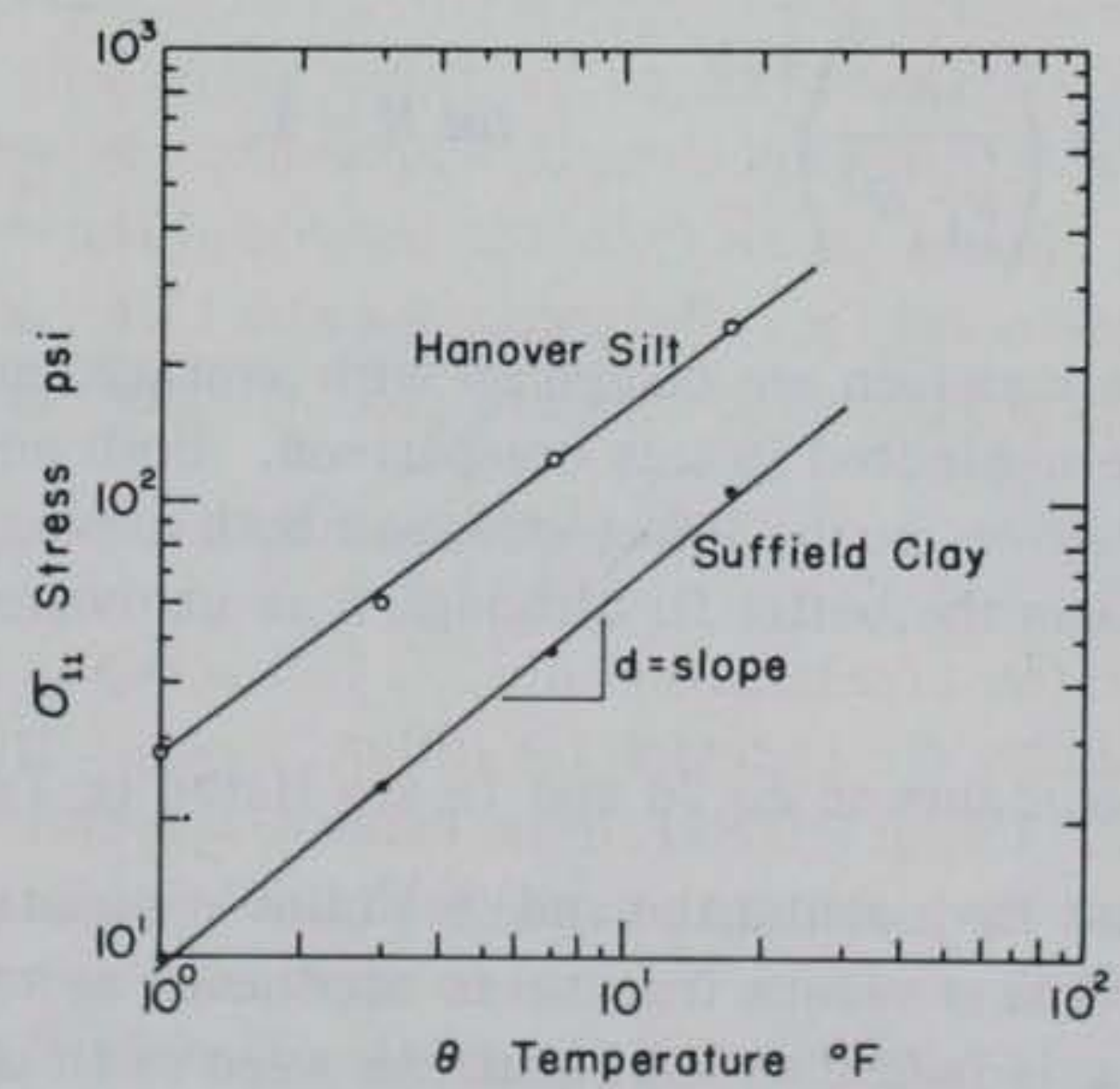

Figure 33. Temperature and stress for unit strain at one hour. 
Table VI. Constants for eq $7 \mathrm{~d}$.

\begin{tabular}{ccccccc} 
Material & $k$ & $a$ & $\begin{array}{c}\sigma_{01} \\
(p \mathrm{psi})\end{array}$ & $b$ & $d$ & $\begin{array}{c}\sigma_{11} \\
(\text { psi })\end{array}$ \\
\hline Hanover silt & .213 & .79 & $190\left(1.31 \mathrm{MN} / \mathrm{m}^{2}\right)$ & .353 & .76 & $280\left(1.93 \mathrm{MN} / \mathrm{m}^{2}\right)$ \\
Suffield clay & .328 & .89 & $110\left(.757 \mathrm{MN} / \mathrm{m}^{2}\right)$ & .352 & .84 & $95\left(0.654 \mathrm{MN} / \mathrm{m}^{2}\right)$ \\
\hline
\end{tabular}

more realistic in practical problems to use eq 4 (Vialov's) and 7d where a rough estimate of the strains will suffice. To provide an evaluation of strain of the specific material involved, a detailed testing program should be used where individual undisturbed soil specimens are tested under in situ stress and temperature conditions.

Equation $7 \mathrm{a}$ or $7 \mathrm{c}$ provides a means for predicting the long-term creep strains at a given stress by observing the first few hours of a creep test. To use these equations, values for $M, \epsilon_{1}$ and $\dot{\epsilon}_{1}$ must be found. These constants can be determined from a creep test of about 8 hours' duration. The value of $\epsilon_{1}$, the strain at $1 \mathrm{hr}$, can be read directly from the time-strain curve; $\dot{\epsilon}_{1}$, the strain rate at $1 \mathrm{hr}$, and $M$ can be determined graphically using the slopes of the tangents to the strain vs time curve on arithmetic coordinates of times of $1 / 2$ hour and 1 hour after stress application (Fig. 34) or by using the $\log \dot{\epsilon}$ vs $\log 1 / t$ curves for the first $8 \mathrm{hr}$ of creep test data (see Fig. 21 and 22). The logarithmic coordinate method predicts long-term strains that are in close agreement with test data; however, this method requires the determination of several strain rates. The arithmetic coordinate method provides a simple, rapid means for predicting strain but it is not as accurate as the method using the $\log \epsilon$ vs $\log 1 / t$ curves. Strain curves predicted by eq $7 \mathrm{a}$ using both the arithmetic coordinates and the logarithmic methods for determining $\epsilon_{1}$ and $M$ are compared with test data in Figure 35.

Strains observed near the end of the individual creep tests and strains predicted by eq $7 \mathrm{a}$ for the same times are presented in the last two columns of Table VII. A comparison of these strains for the individual specimens shows that in general the predicted strains using eq $7 \mathrm{a}$ are smaller than those observed in the creep tests.

A logarithmic plot of the strains predicted by eq $7 \mathrm{a}$ vs the observed strains from creep tests is presented in Figure 36. The dashed line on the figure represents the ideal relationship between the predicted and the observed strain (i.e. complete agreement between observed and predicted values). The solid line is a least squares fit of the combined Hanover silt and Suffield clay strain data. The two lines are nearly parallel, with the solid line offset downward from the dashed line, indicating again that the predicted strains are consistently unconservative.

\section{Strength-time}

Since the soils tested in the investigation did not fail abruptly by rupture but instead deformed continuously in a plastic manner, the criterion for failure was arbitrarily taken as the time the specimen strain reached $20 \%$. Using $20 \%$ strain as failure, strength vs time curves for different soil temperatures are obtained by plotting the time to failure against the corresponding applied creep stress (see Fig. 37). The curves are drawn to approach asymptotically the value of maximum test stresses that did not result in failure during the test period. The total number of hours that the nonfailure tests were conducted is indicated in parentheses at the right side of the graph. 




$\dot{\epsilon}=\frac{d \epsilon}{d t}=$ slope of tangent

$\dot{\epsilon}_{1}=\frac{.001815-.001767}{2-0}=.0000242$

$\dot{\epsilon}_{.5}=\frac{.001800-.001747}{1-0}=.000053 \quad M=\frac{\lg \left(t_{1} / t .5\right)}{\lg \left(\dot{\epsilon}_{.5} / \dot{\epsilon}_{1}\right)}=.888$

a. Hanover silt, HAS $10 \mathrm{~V}, 330 \mathrm{psi}, 15^{\circ} \mathrm{F}$.

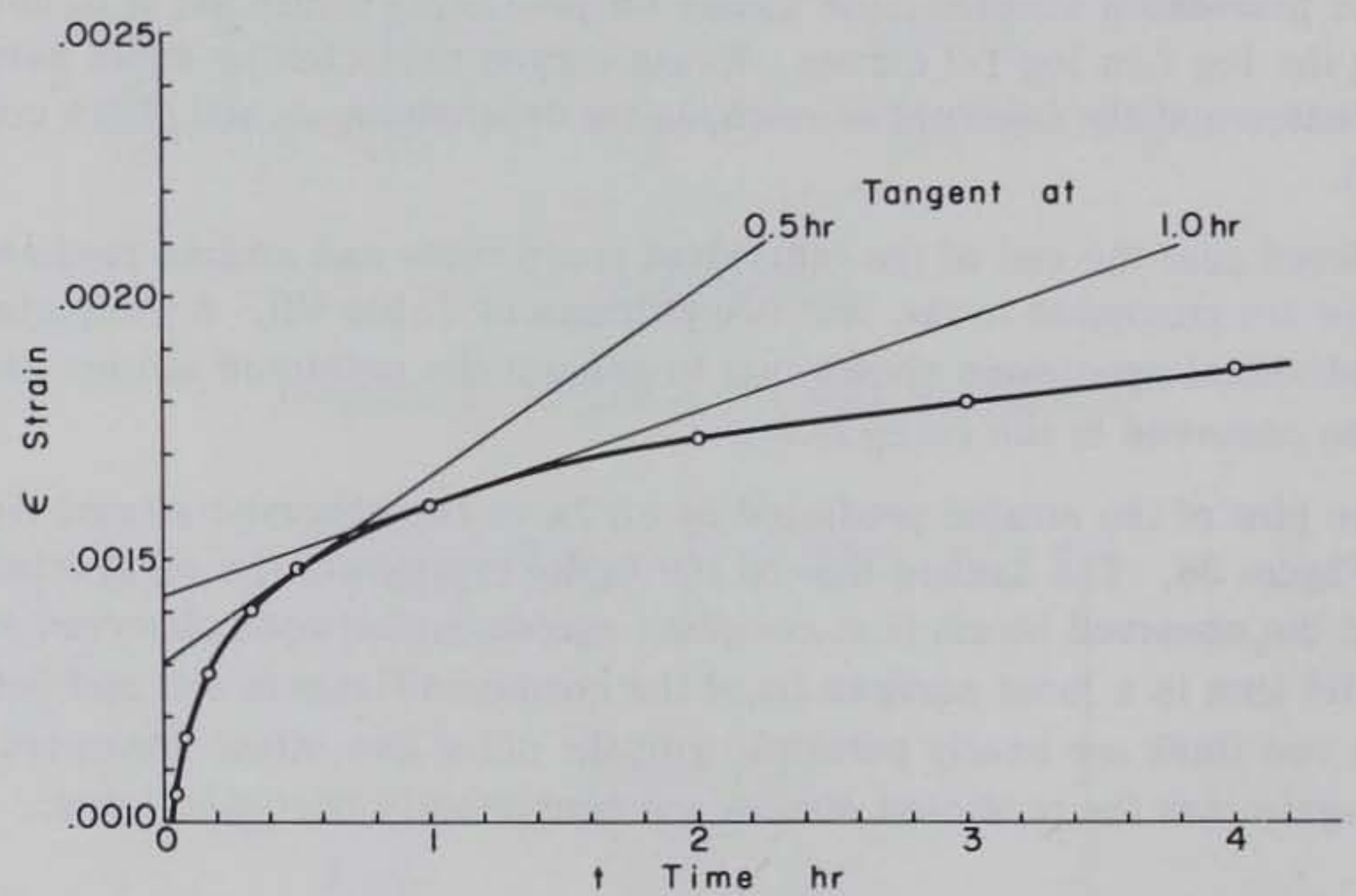

$\dot{\epsilon}=\frac{d \epsilon}{d t}=$ slope of tangent

$\dot{\epsilon}_{1}=\frac{.001955-.001430}{3-0}=.000175$

$\dot{\epsilon}_{.5}=\frac{.00237-.00130}{3-0}=.000323$

$M=\frac{\lg \left(t_{1} / t .5\right)}{\lg \left(\dot{\epsilon}_{.5} / \dot{\epsilon}_{1}\right)}=1.132$

b. Suffield clay, SFC $111,140 \mathrm{psi}, 15^{\circ} \mathrm{F}$.

Figure 34. Time and strain. 


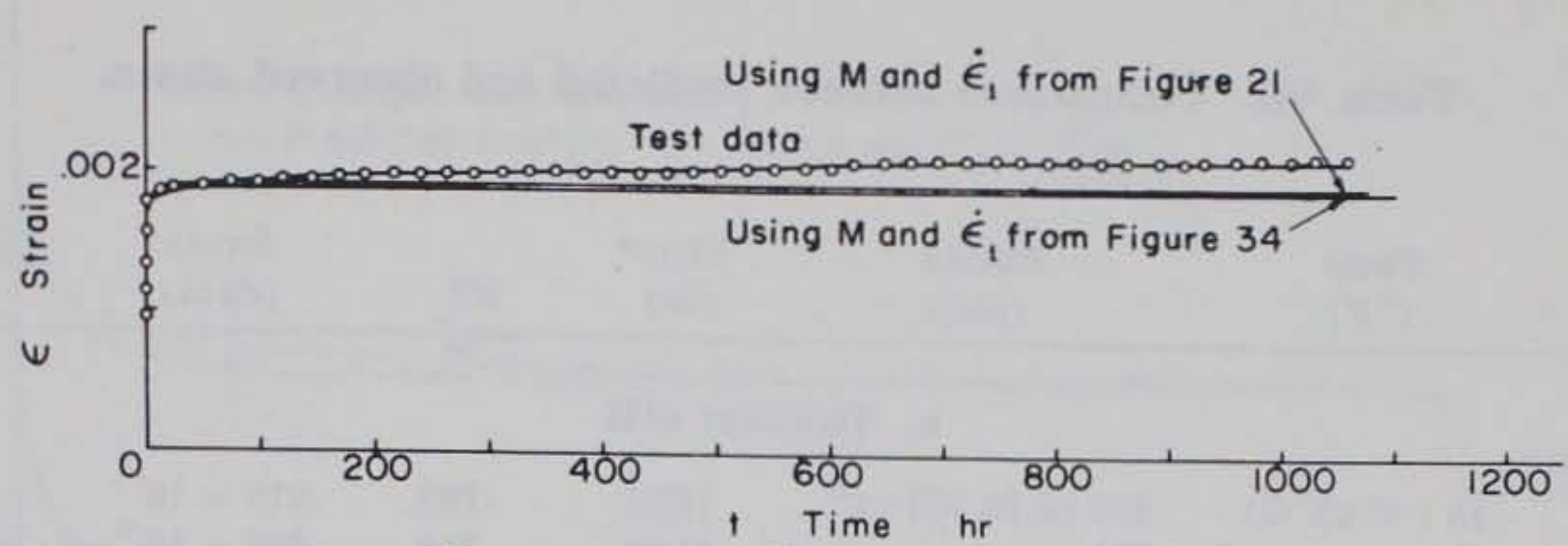

a. Hanover silt, $H A S 10 \mathrm{~V}, 330 \mathrm{psi}, 15^{\circ} \mathrm{F}$.

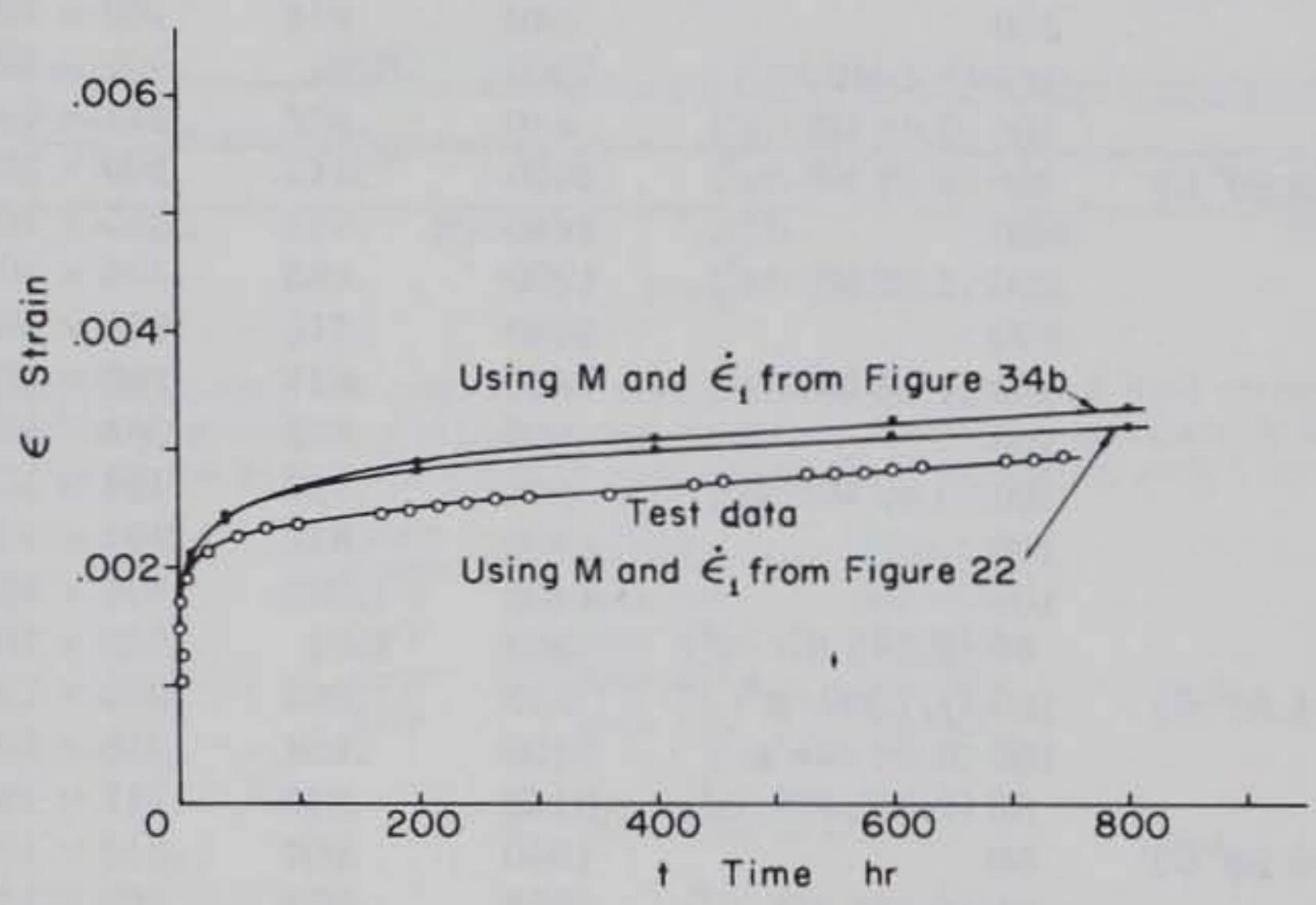

b. Suffield clay, SFC $111,140 \mathrm{psi}, 15^{\circ} \mathrm{F}$.

Figure 35. Time and strain.

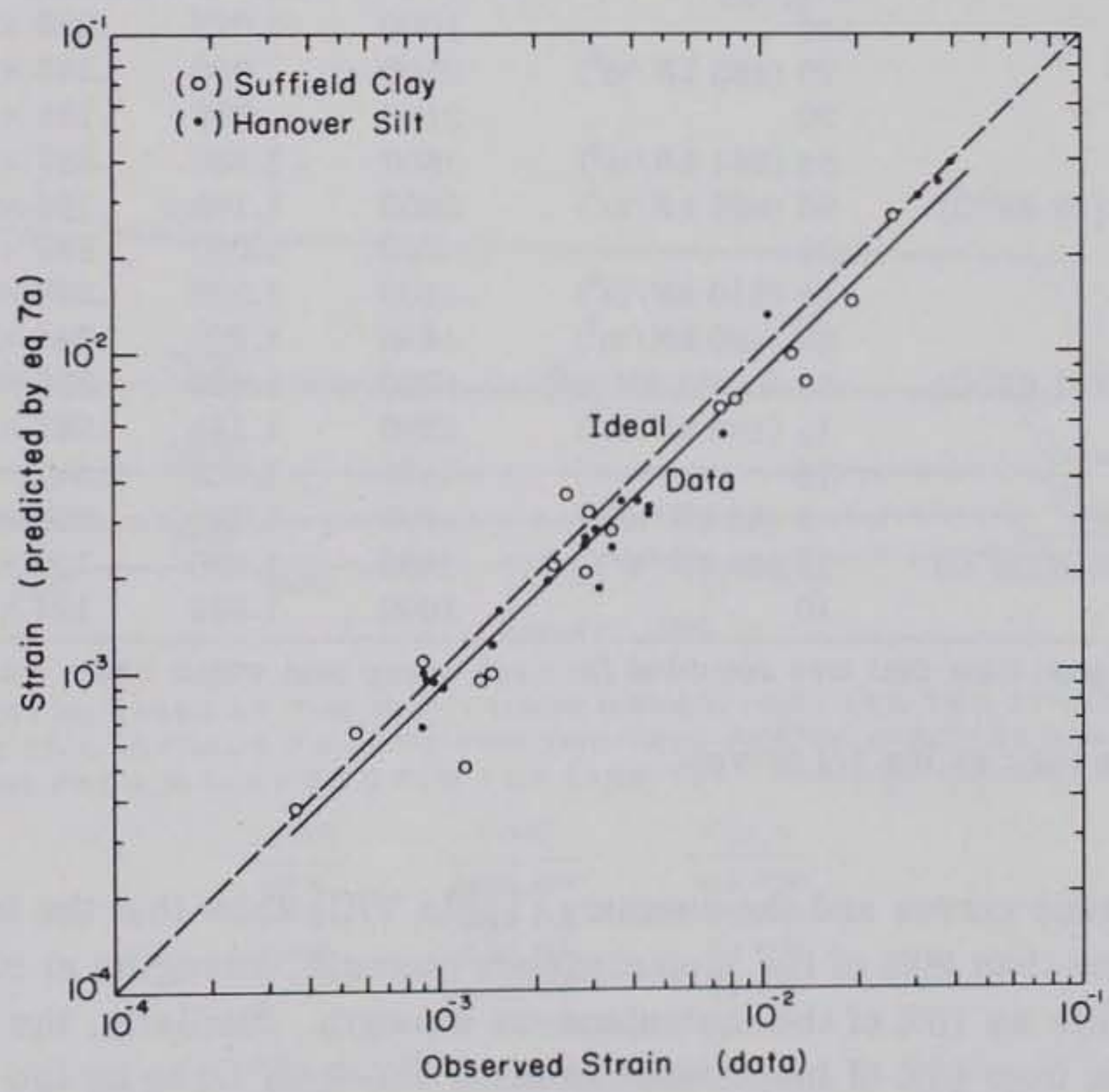

Figure 36. Observed strain vs predicted strain. 
Table VII. Comparison between predicted and observed strain.

\begin{tabular}{|c|c|c|c|c|c|c|}
\hline Specimen & $\begin{array}{c}\text { Temp } \\
\left({ }^{\circ} \mathrm{F}\right)\end{array}$ & $\begin{array}{c}\text { Stress } \\
(p s i)\end{array}$ & $\begin{array}{c}\text { Time* } \\
(\mathrm{hr})\end{array}$ & $M \dagger$ & $\begin{array}{l}\text { Strain } \\
\text { (data) }\end{array}$ & $\begin{array}{c}\text { Strain } \\
\text { (computed by } \\
\text { eq } 7 \mathrm{a})\end{array}$ \\
\hline
\end{tabular}

\section{a. Hanover silt}

$\begin{array}{ll}\text { HAS-10V } & 15\left(-9.45^{\circ} \mathrm{C}\right) \\ \text { HAS-24V } & 15 \\ \text { HAS-20 } & 15 \\ \text { HAS-21 } & 15 \\ \text { HAS-4 } & 15 \\ \text { HAS-9 } & 15 \\ \text { HAS-33V } & 25\left(-3.89^{\circ} \mathrm{C}\right) \\ \text { HAS-36V } & 25 \\ \text { HAS-32 } & 25 \\ \text { HAS-41 } & 25 \\ \text { HAS-6 } & 25 \\ \text { HAS-14 } & 25 \\ \text { HAS-12 } & 25 \\ \text { HAS-34 } & 25 \\ \text { HAS-102 } & 25 \\ \text { HAS- } 17 & 25 \\ \text { HAS-79V } & 29\left(-1.67^{\circ} \mathrm{C}\right) \\ \text { HAS-62 } & 29 \\ \text { HAS-83 } & 29 \\ \text { HAS-101 } & 31\left(-0.56^{\circ} \mathrm{C}\right) \\ \text { HAS-73 } & 31 \\ \text { HAS-107 } & 31\end{array}$

$\begin{array}{lrc}330\left(2.28 \mathrm{MN} / \mathrm{m}^{2}\right) & 1080 & .763 \\ 330 & 1100 & .715 \\ 200\left(1.38 \mathrm{MN} / \mathrm{m}^{2}\right) & 840 & .914 \\ 200 & 840 & .914 \\ 160\left(1.1 \mathrm{MN} / \mathrm{m}^{2}\right) & 1200 & 1.01 \\ 100\left(0.69 \mathrm{MN} / \mathrm{m}^{2}\right) & 840 & .936 \\ 330\left(2.28 \mathrm{MN} / \mathrm{m}^{2}\right) & 2850 & .745 \\ 330 & 4440 & .745 \\ 200\left(1.38 \mathrm{MN} / \mathrm{m}^{2}\right) & 4300 & .688 \\ 200 & 4300 & .715 \\ 150\left(1.03 \mathrm{MN} / \mathrm{m}^{2}\right) & 500 & .817 \\ 150 & 500 & .802 \\ 100\left(0.69 \mathrm{MN} / \mathrm{m}^{2}\right) & 500 & .923 \\ 100 & 1700 & .813 \\ 100 & 1400 & 1.025 \\ 50\left(0.345 \mathrm{MN} / \mathrm{m}^{2}\right) & 500 & 1.01 \\ 160\left(1.1 \mathrm{MN} / \mathrm{m}^{2}\right) & 550 & .808 \\ 100\left(0.69 \mathrm{MN} / \mathrm{m}^{2}\right) & 2400 & .834 \\ 50\left(0.345 \mathrm{MN} / \mathrm{m}^{2}\right) & 2150 & .840 \\ 50 & 1900 & .807 \\ 25\left(0.173 \mathrm{MN} / \mathrm{m}^{2}\right) & 2000 & .955 \\ 25 & 1000 & 1.035\end{array}$

$.217 \times 10^{-2}$
$.288 \times 10^{-2}$
$.973 \times 10^{-3}$
$.102 \times 10^{-2}$
$.907 \times 10^{-3}$
$.344 \times 10^{-3}$
$.309 \times 10^{-1}$
$.355 \times 10^{-1}$
$.456 \times 10^{-2}$
$.456 \times 10^{-2}$
$.280 \times 10^{-2}$
$.365 \times 10^{-2}$
$.154 \times 10^{-2}$
$.891 \times 10^{-3}$
$.304 \times 10^{-2}$
$.908 \times 10^{-3}$
$.395 \times 10^{-1}$
$.758 \times 10^{-2}$
$.147 \times 10^{-2}$
$.413 \times 10^{-2}$
$.305 \times 10^{-2}$
$.105 \times 10^{-2}$

$.193 \times 10^{-2}$
$.262 \times 10^{-2}$
$.938 \times 10^{-3}$
$.879 \times 10^{-2}$
$.935 \times 10^{-3}$
$.236 \times 10^{-3}$
$.309 \times 10^{-1}$
$.348 \times 10^{-1}$
$.310 \times 10^{-2}$
$.324 \times 10^{-2}$
$.261 \times 10^{-2}$
$.346 \times 10^{-2}$
$.153 \times 10^{-2}$
$.661 \times 10^{-3}$
$.279 \times 10^{-2}$
$.945 \times 10^{-3}$
$.391 \times 10^{-1}$
$.553 \times 10^{-2}$
$.121 \times 10^{-2}$
$.336 \times 10^{-2}$
$.183 \times 10^{-2}$
$.130 \times 10^{-2}$

b. Suffield clay

\begin{tabular}{lllrrrl} 
SFC-101V & $15\left(-9.45^{\circ} \mathrm{C}\right)$ & $140\left(970 \mathrm{kN} / \mathrm{m}^{2}\right)$ & 1000 & .942 & $.743 \times 10^{-2}$ & $.675 \times 10^{-2}$ \\
SFC-111V & 15 & 140 & 740 & 1.037 & $.295 \times 10^{-2}$ & $.218 \times 10^{-2}$ \\
SFC-123V & 15 & 140 & 1000 & 1.029 & $.230 \times 10^{-2}$ & $.218 \times 10^{-2}$ \\
SFC-108 & 15 & $70\left(483 \mathrm{kN} / \mathrm{m}^{2}\right)$ & 2100 & .920 & $.145 \times 10^{-2}$ & $.980 \times 10^{-3}$ \\
$\mathrm{SFC}-110$ & 15 & 70 & 2180 & .998 & $.135 \times 10^{-2}$ & $.938 \times 10^{-3}$ \\
$\mathrm{SFC}-106$ & 15 & $35\left(241 \mathrm{kN} / \mathrm{m}^{2}\right)$ & 1600 & 1.188 & $.887 \times 10^{-3}$ & $.108 \times 10^{-2}$ \\
$\mathrm{SFC}-58 \mathrm{~V}$ & $25\left(-3.89^{\circ} \mathrm{C}\right)$ & $90\left(620 \mathrm{kN} / \mathrm{m}^{2}\right)$ & 2300 & 1.145 & $.192 \times 10^{-1}$ & $.144 \times 10^{-1}$ \\
$\mathrm{SFC}-84 \mathrm{~V}$ & 25 & 90 & 700 & 1.050 & $.839 \times 10^{-2}$ & $.714 \times 10^{-2}$ \\
$\mathrm{SFC}-81$ & 25 & $45\left(310 \mathrm{kN} / \mathrm{m}^{2}\right)$ & 1400 & 1.020 & $.250 \times 10^{-2}$ & $.364 \times 10^{-2}$ \\
$\mathrm{SFC}-80$ & 25 & $23\left(160 \mathrm{kN} / \mathrm{m}^{2}\right)$ & 1450 & 1.090 & $.548 \times 10^{-3}$ & $.655 \times 10^{-3}$ \\
$\mathrm{SFC}-1$ & $29\left(-1.67^{\circ} \mathrm{C}\right)$ & $33.5\left(231 \mathrm{kN} / \mathrm{m}^{2}\right)$ & 4000 & 1.690 & $.256 \times 10^{-1}$ & $.271 \times 10^{-1}$ \\
$\mathrm{SFC}-64$ & 29 & $15\left(103 \mathrm{kN} / \mathrm{m}^{2}\right)$ & 1390 & 1.145 & $.287 \times 10^{-2}$ & $.203 \times 10^{-2}$ \\
$\mathrm{SFC}-70$ & 29 & 15 & 1400 & 1.058 & $.344 \times 10^{-2}$ & $.278 \times 10^{-2}$ \\
$\mathrm{SFC}-78$ & 29 & $6\left(41 \mathrm{kN} / \mathrm{m}^{2}\right)$ & 790 & 1.020 & $.360 \times 10^{-3}$ & $.379 \times 10^{-3}$ \\
$\mathrm{SFC}-65$ & $31\left(-0.56^{\circ} \mathrm{C}\right)$ & $10\left(69 \mathrm{kN} / \mathrm{m}^{2}\right)$ & 1300 & 1.130 & $.139 \times 10^{-1}$ & $.811 \times 10^{-2}$ \\
$\mathrm{SFC}-79$ & 31 & 10 & 1000 & 1.340 & $.124 \times 10^{-1}$ & $.988 \times 10^{-2}$ \\
\hline
\end{tabular}

* Time is the longest time that was recorded for each creep test which had a maximum strain of less than $20 \%$.

$\dagger M=$ slope of the $\log \dot{\epsilon}$ vs $\log 1 / t$ curves.

The strength-time curves and the summary (Table VIII) show that the long-term strength of the Suffield clay is less than $20 \%$ of the instantaneous strength; strengths at $29^{\circ}$ and $31^{\circ} \mathrm{F}\left(-1.67^{\circ}\right.$ and $-0.56^{\circ} \mathrm{C}$ ) were as low as $10 \%$ of the instantaneous strength. Similarly, the long-term strength of the Hanover silt ranges from $43 \%$ of instantaneous at $15^{\circ} \mathrm{F}\left(-9.45^{\circ} \mathrm{C}\right)$ to as low as $17 \%$ at $31^{\circ} \mathrm{F}\left(-0.56^{\circ} \mathrm{C}\right)$. These results are generally in agreement with results reported by Vialov (1962) where the long-term cohesion ranged from 37 to $18 \%$ of the instantaneous cohesion for a frozen sandy silt. 


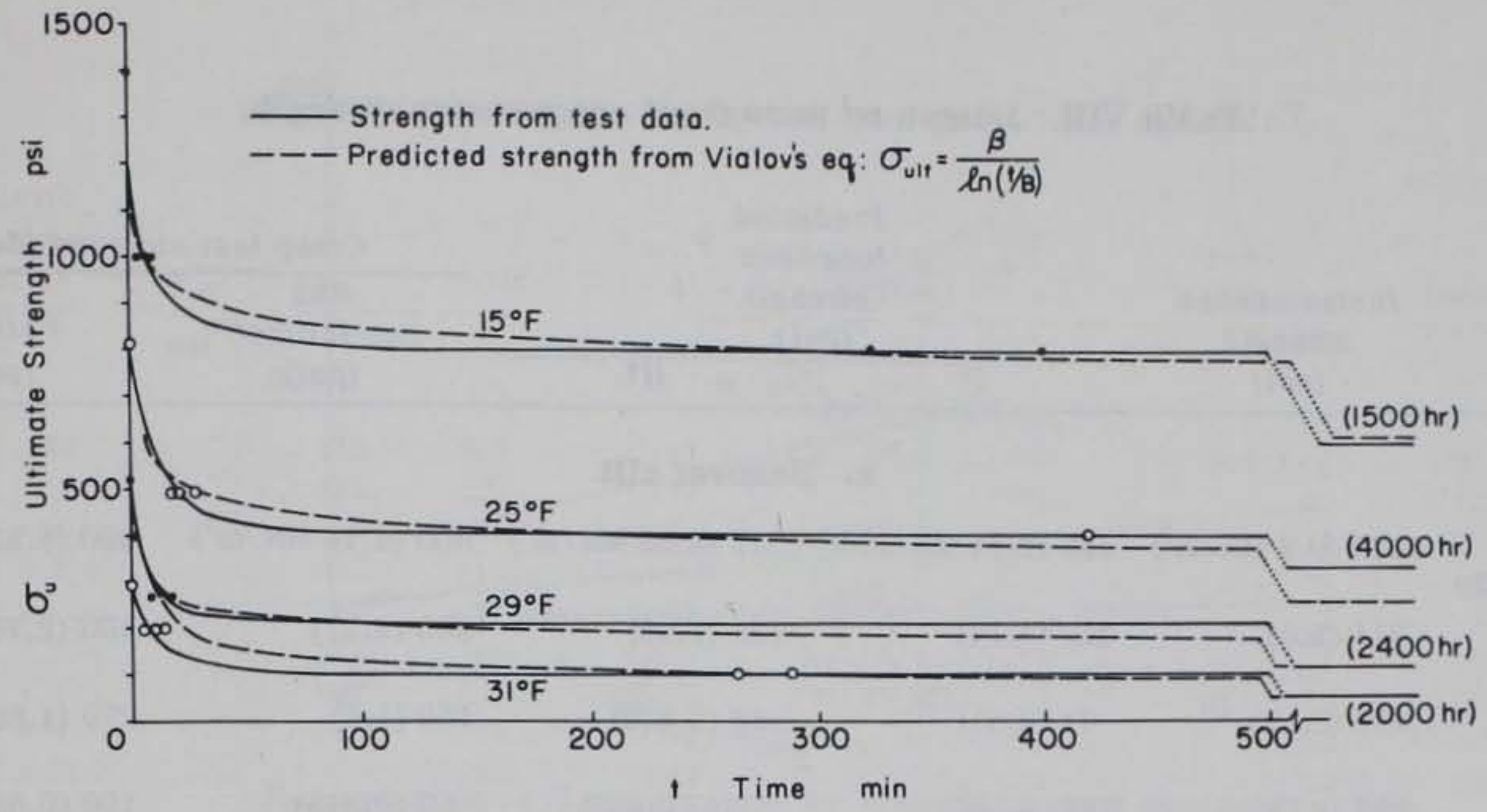

NOTE: HORIZONTAL LINES AT THE RIGHT HAND MARGIN INDICATE THE STRESSES SUSTAINED BY THE SOIL WI THOUT FAILURE FOR THE TEST PERIOD INDICATED IN PARENTHESES. STRENGTHS FROM VIALOV'S EQ FOR THE SAME TEST PERIODS ARE LISTED BELOW:

\begin{tabular}{|c|c|c|}
\hline TEMP & TIME & $\sigma_{\cup L T}$ \\
\hline $15^{\circ} \mathrm{F}$ & $1500 \mathrm{HR}$ & 608 PSI \\
\hline $25^{\circ} \mathrm{F}$ & $4000 \mathrm{HR}$ & $246 \mathrm{PSI}$ \\
\hline $29^{\circ} \mathrm{F}$ & $2400 \mathrm{HR}$ & 109 PSI \\
\hline $31^{\circ} \mathrm{F}$ & $2000 \mathrm{HR}$ & $48 P S I$ \\
\hline
\end{tabular}

a. Hanover silt.

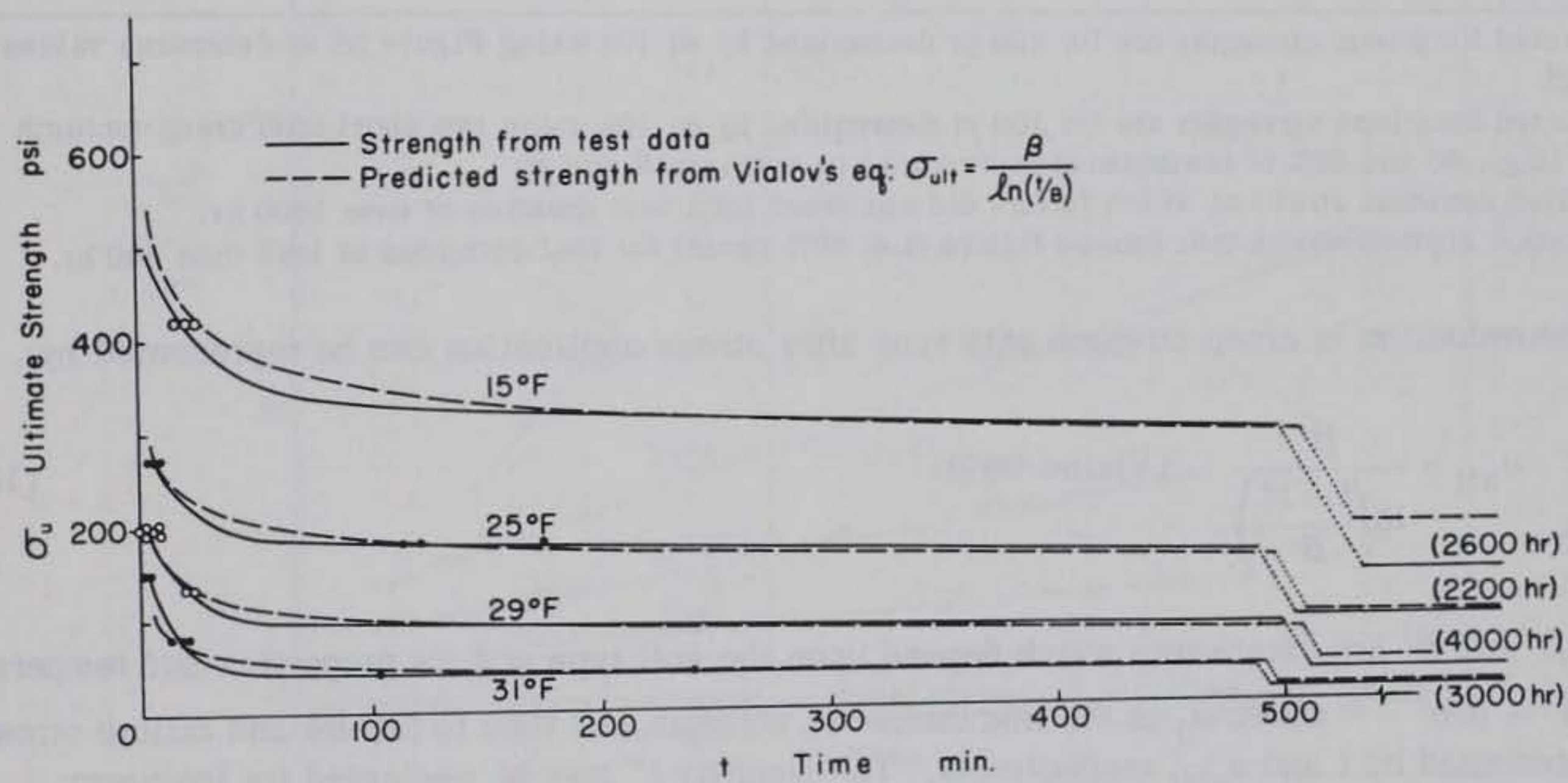

NOTE: HORIZONTAL LINES AT THE RIGHT HAND MARGIN INDICATE THE STRESSES SUSTAINED BY THE SOIL WITHOUT FAILURE FOR THE TEST PERIOD INDICATED IN PARENTHESES. STRENGTHS FROM VIALOV'S EQ FOR THE SAME TEST PERIODS ARE LISTED BELOW:

\begin{tabular}{|c|c|c|}
\hline TEMP & TIME & $\sigma_{\text {UL T }}$ \\
\hline $15^{\circ} \mathrm{F}$ & $2600 \mathrm{HR}$ & 182 PSI \\
\hline $25^{\circ} \mathrm{F}$ & $2200 \mathrm{HR}$ & $95 \mathrm{PSI}$ \\
\hline $29^{\circ} \mathrm{F}$ & $4000 \mathrm{HR}$ & 53 PSI \\
\hline $31^{\circ} \mathrm{F}$ & $3000 \mathrm{HR}$ & $20 \mathrm{PSI}$ \\
\hline
\end{tabular}

b. Suffield clay.

Figure 37. Ultimate strength and time to failure. 
Table VIII. Long-term unconfined compressive strength.

\begin{tabular}{|c|c|c|c|c|c|}
\hline \multirow[b]{3}{*}{ Temp } & \multirow{3}{*}{$\begin{array}{l}\text { Instantaneous } \\
\text { strength } \\
\text { (psi) }\end{array}$} & \multirow{2}{*}{\multicolumn{2}{|c|}{$\begin{array}{l}\text { Predicted } \\
\text { long-term } \\
\text { strength } \\
\text { (psi) }\end{array}$}} & \multicolumn{2}{|c|}{ Creep test stresses (data) } \\
\hline & & & & \multirow{2}{*}{$\begin{array}{c}\text { Max } \\
\text { non-failure** } \\
\text { (psi) }\end{array}$} & \multirow{2}{*}{$\begin{array}{c}\text { Failure } \dagger \dagger \\
\text { (psi) }\end{array}$} \\
\hline & & $I^{*}$ & $\mathrm{II}^{\dagger}$ & & \\
\hline \multicolumn{6}{|c|}{ a. Hanover silt } \\
\hline $\begin{array}{c}15^{\circ} \mathrm{F} \\
\left(-9.45^{\circ} \mathrm{C}\right)\end{array}$ & $1390\left(9.9 \mathrm{MN} / \mathrm{m}^{2}\right)$ & $456\left(3.14 \mathrm{MN} / \mathrm{m}^{2}\right)$ & $511\left(3.52 \mathrm{MN} / \mathrm{m}^{2}\right)$ & $600\left(4.14 \mathrm{MN} / \mathrm{m}^{2}\right)$ & $800\left(5.51 \mathrm{MN} / \mathrm{m}^{2}\right)$ \\
\hline $\begin{array}{c}25 \\
(-3.89)\end{array}$ & $811(5.6)$ & $166(1.14)$ & $172(1.18)$ & $330(2.27)$ & $400(2.76)$ \\
\hline $\begin{array}{c}29 \\
(-1.67)\end{array}$ & $519(3.58)$ & $74(0.51)$ & $83(0.572)$ & $160(1.1)$ & $270(1.86)$ \\
\hline $\begin{array}{c}31 \\
(-0.556)\end{array}$ & $293(2.02)$ & $27(0.186)$ & $35.5(0.255)$ & $50(0.345)$ & $100(0.689)$ \\
\hline \multicolumn{6}{|c|}{ b. Suffield clay } \\
\hline $\begin{array}{c}15^{\circ} \mathrm{F} \\
\left(-9.45^{\circ} \mathrm{C}\right)\end{array}$ & $711\left(4.9 \mathrm{MN} / \mathrm{m}^{2}\right)$ & $121\left(0.835 \mathrm{MN} / \mathrm{m}^{2}\right)$ & $147\left(1.02 \mathrm{MN} / \mathrm{m}^{2}\right)$ & $140\left(0.966 \mathrm{MN} / \mathrm{m}^{2}\right)$ & $280\left(1.93 \mathrm{MN} / \mathrm{m}^{2}\right)$ \\
\hline $\begin{array}{c}25 \\
(-3.89)\end{array}$ & $448(3.09)$ & $65(0.437)$ & $74(0.51)$ & $90(0.62)$ & $182(1.255)$ \\
\hline $\begin{array}{c}29 \\
(-1.67)\end{array}$ & $333(2.3)$ & $33(0.228)$ & $62(0.427)$ & $33.5(0.231)$ & $67(0.462)$ \\
\hline $\begin{array}{c}31 \\
(-0.556)\end{array}$ & $206(1.42)$ & $12(0.083)$ & $22(0.152)$ & $20.7(0.142)$ & $41.4(0.285)$ \\
\hline
\end{tabular}

* Predicted long-term strengths are for $100 \mathrm{yr}$ determined by eq $10 \mathrm{a}$ using Figure 38 to determine values for $B$ and $\beta$.

$\dagger$ Pređicted long-term strengths are for $100 \mathrm{yr}$ determined by eq 10a using two short-term creep strength values (e.g., 60 and $40 \%$ of instantaneous streng th) to evaluate $B$ and $\beta$.

** Applied constant stress at which failure did not occur for a test duration of over $1500 \mathrm{hr}$.

$\dagger \dagger$ Constant applied stress that caused failure (i.e. $20 \% \mathrm{strain}$ ) for test durations of les s than $500 \mathrm{hr}$.

The reduction in creep strength with time after stress application can be represented by:

$$
\sigma_{\mathrm{ult}}=\frac{\beta^{\prime}}{\ln \left(\frac{t+t^{*}}{B^{\prime}}\right)} \quad \text { (Vialov 1959) }
$$

where $\beta^{\prime}$ and $B^{\prime}$ are parameters which depend upon the soil type and its properties and temperatures, $t^{*}=B \mathrm{e}^{\beta / \sigma_{0}}$ where $\sigma_{0}$ is the instantaneous strength, and time to failure and failure stress are represented by $t$ and $\sigma_{\mathrm{ult}}$, respectively. The quantity $t^{*}$ may be neglected for long-term strengths. Also, for convenience in graphic plotting, the logarithm to the base ten is used to evaluate $\beta^{\prime}$ and $B^{\prime}$; then eq 10 becomes:

$$
\sigma_{\mathrm{ult}}=\frac{\beta}{\log (\mathrm{t} / B)} .
$$

The values of parameters $\beta$ and $B$ can be determined by either developing a plot of $1 / \sigma_{\text {ult }}$ vs time or by using results from short-term creep tests. The method suggested by Vialov for determining these parameters from $1 / \sigma_{\mathrm{ult}}$ vs log time curves is indicated in Figure 38 . The disadvantages of this method are the extensive test program involving several tests, length of time for the tests of lower stress levels, and care required to perform the creep-strength tests lasting more than a couple of days. Using the results of short-term creep tests for predicting long-term 


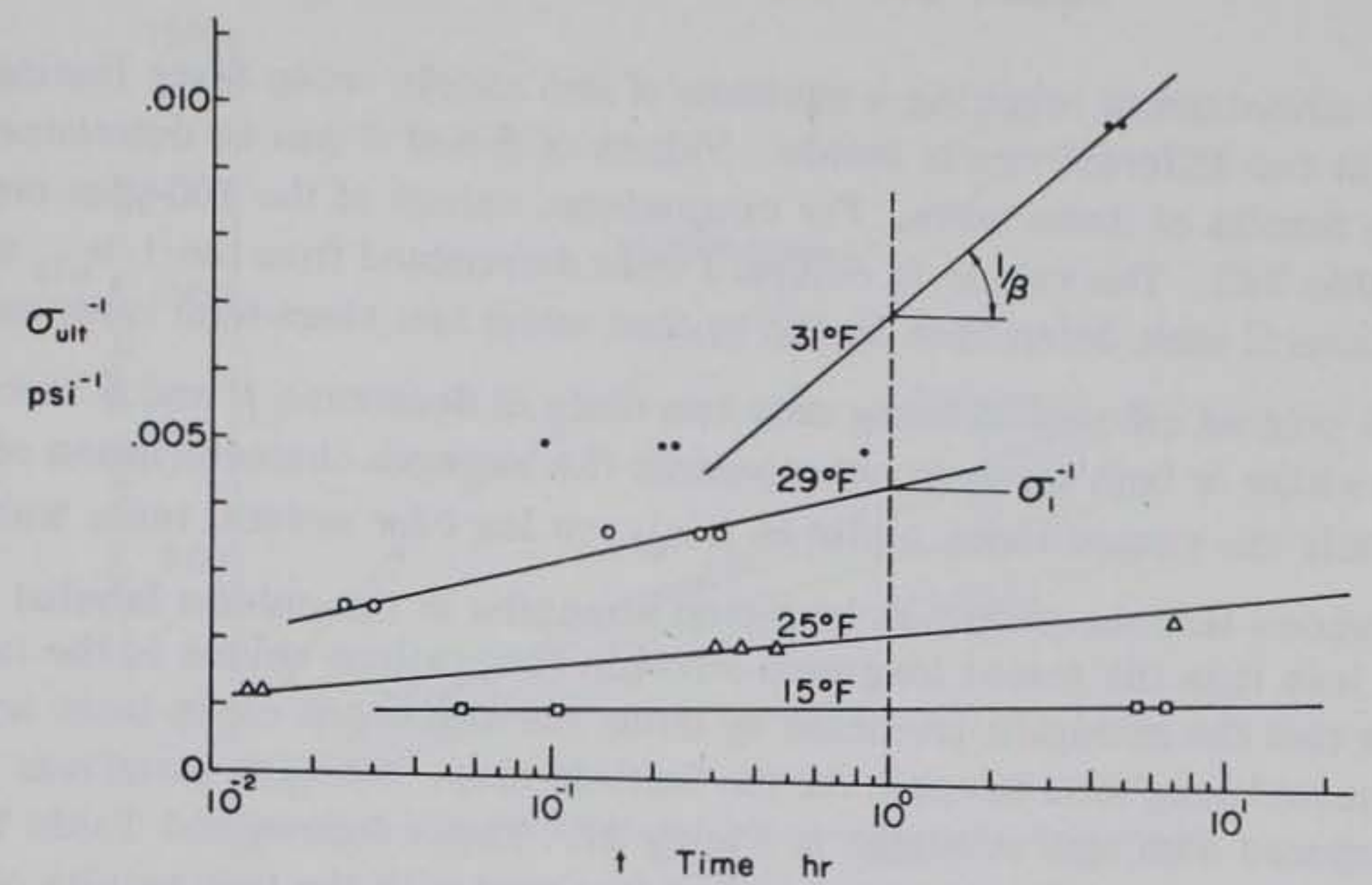

Determination of $\beta$ and $B$ values for Vialov's strength equation:
$\sigma_{\mathrm{u}}=\frac{\beta}{\log (t / B)}$
$\frac{1}{\beta}=$ slope
$\log \frac{1}{B}=\frac{\beta}{\sigma_{1}}$

a. Hanover silt.

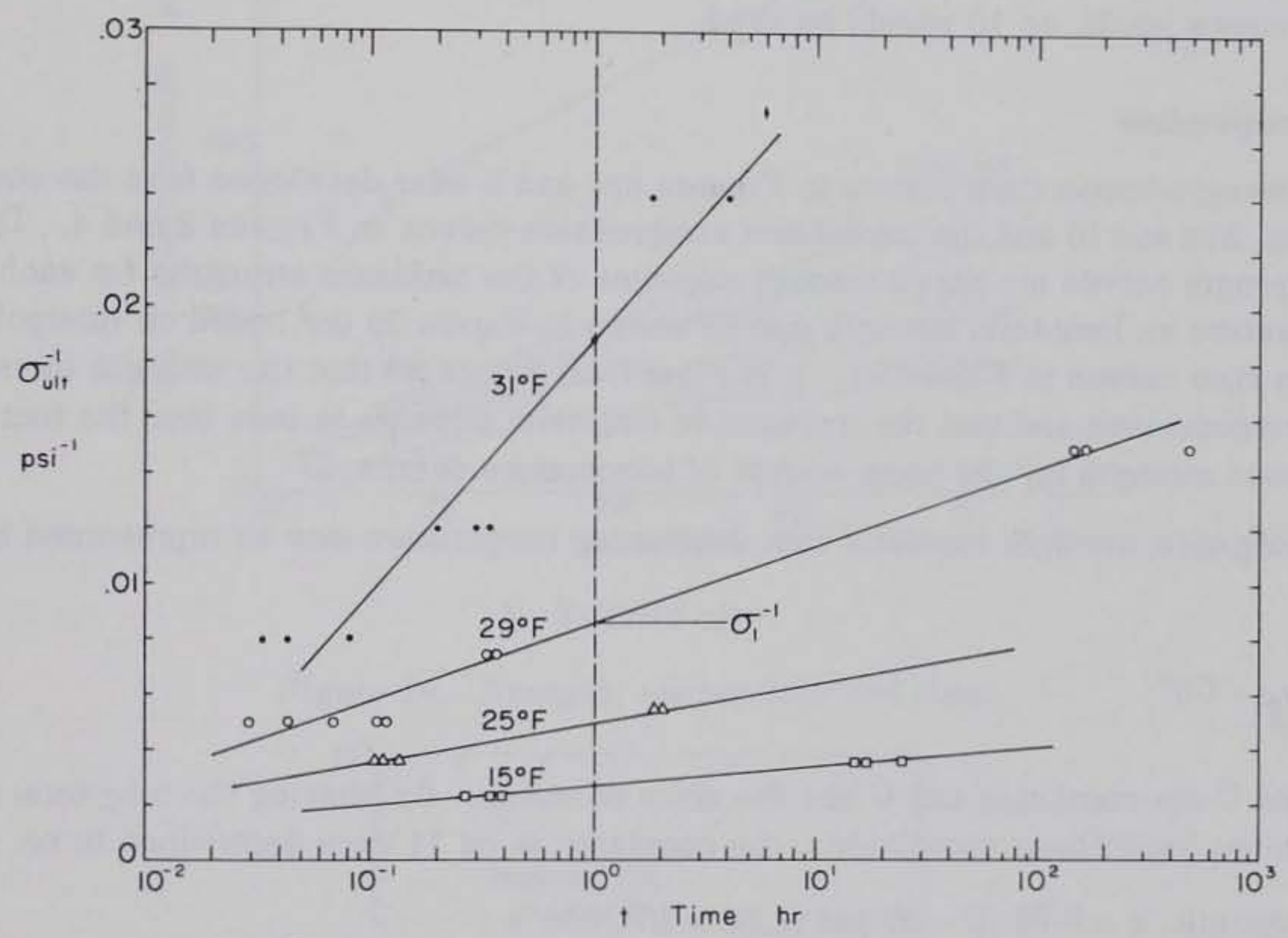

Determination of $\beta$ and $B$ values for Vialov's strength equation:
$\sigma_{\mathrm{u}}=\frac{\beta}{\log (t / B)}$
$\frac{1}{\beta}=$ slope
$\log \frac{1}{B}=\frac{\beta}{\sigma_{1}}$

b. Suffield clay.

Figure 38. Time and reciprocal of ultimate stress. 
strength has the advantage of requiring a minimum of two simple creep tests lasting about 8 hours to be performed at two different stress levels. Values of $\beta$ and $B$ can be determined by solving eq 10a using the results of these tests. For comparison, values of the 100 -year predicted strengths are shown in Table VIII. The values in column I were determined from the $1 / \sigma_{\mathrm{ult}}$ vs $\log t$ curves and those in column II were determined by the method using two short-term creep tests.

It should be pointed out that in using only two tests to determine $\beta$ and $B$ there is a risk that the results from either or both tests do not represent the strength characteristics of the soil. Therefore where possible the method using a plot of $1 / \sigma_{\mathrm{ult}}$ vs $\log t$ for several tests would be preferable.

Table VIII shows that the predicted long-term strengths in the column labeled I for all temperatures listed are less than the tested long-term strength (non-failure values in the table). The column labeled II shows that the strengths predicted by using the short-term creep tests are less conservative and exceed the tested long-term strength for the Suffield clay. Strength variations with time predicted by eq 10 are compared with test strengths in Figure 37 . These figures and Table VIII show that the Vialov strength equation (eq 10) is in reasonable agreement with the test results of this investigation.

It is clear from Figure 37 that frozen soil cannot resist a stress greater than $50 \%$ of its instantaneous strength for more than 24 hours. Also, stresses that are to be resisted for 1000 hours must be less than $35 \%$ of the instantaneous strength of the frozen soil.

Vialov's strength equation is empirical and in the simplified form (eq 10a) is not applicable to extremely short periods of loading where a brittle type fracture occurs. When the duration of loading becomes small, eq 10 should be used.

\section{Strength-temperature}

The strength-temperature curves in Figures $39 \mathrm{a}$ and $\mathrm{b}$ were developed from the strength-time curves (Fig. 37a and b) and the unconfined compression curves in Figures 3 and 4. The instantaneous strength curves are drawn through averages of the maximum strengths for each temperature. The temperature vs long-term strength curves shown in Figure 39 are based on interpolation of the strength vs time curves in Figure 37. It is clear from Figure 39 that the strength increases as the temperature decreases and that the increase in long-term strength is less than the increase in instantaneous strength for the same amount of temperature decrease.

The long-term strength increase with decreasing temperature may be represented by the equation:

$$
\sigma_{\ell}=C \theta^{n}
$$

where $n$ and $C$ are constants and $C$ has the units of stress. By plotting the long-term strength vs temperature on logarithmic coordinates, the constants in eq 11 were determined to be:

Hanover silt, $n=0.93 ; C=27 \mathrm{psi}\left(1.86 \times 10^{5} \mathrm{~N} / \mathrm{m}^{2}\right)$

Suffield clay, $n=0.75 ; C=14.5 \mathrm{psi}\left(1 . \times 10^{5} \mathrm{~N} / \mathrm{m}^{2}\right)$.

The terms $\beta$ and $B$ in eq 10a are clearly a function of temperature, as shown in Table IX. Plots in logarithmic coordinates of $\beta$ and $B$ vs temperature are shown in Figures 40 and 41 . Equations for the straight lines shown with the plotted data are: 


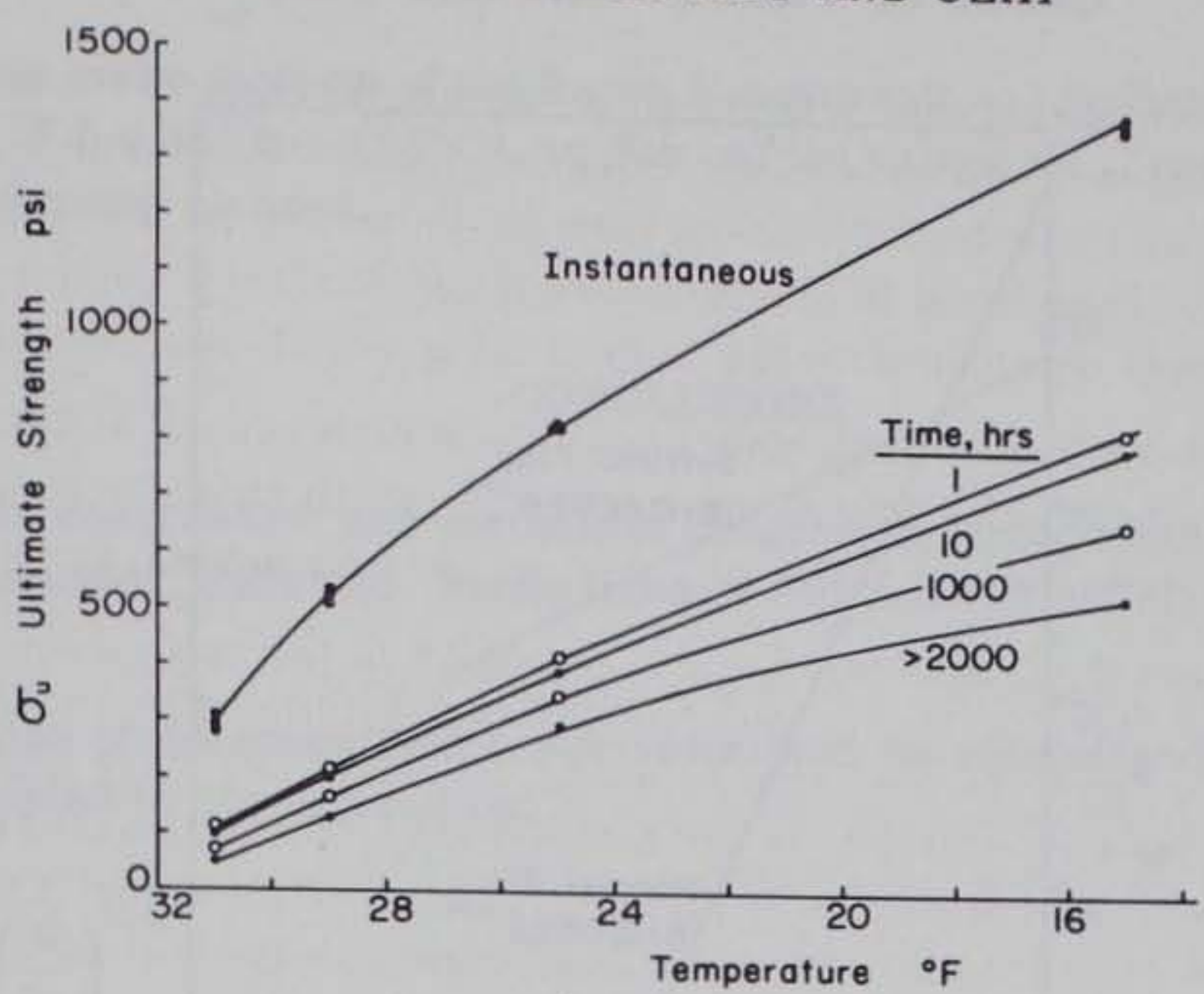

a. Hanover silt.

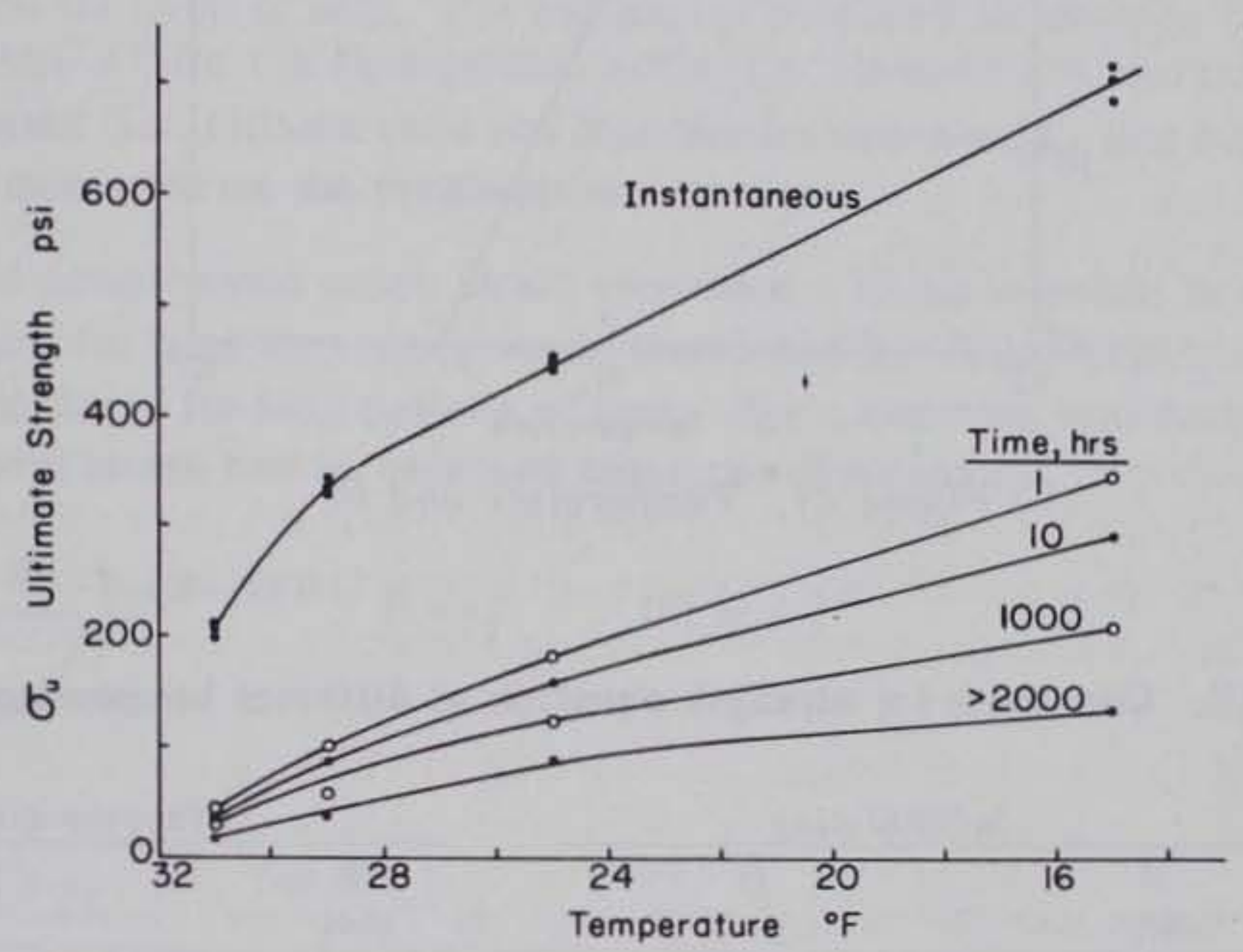

b. Suffield clay.

Figure 39. Strength, temperature and time.

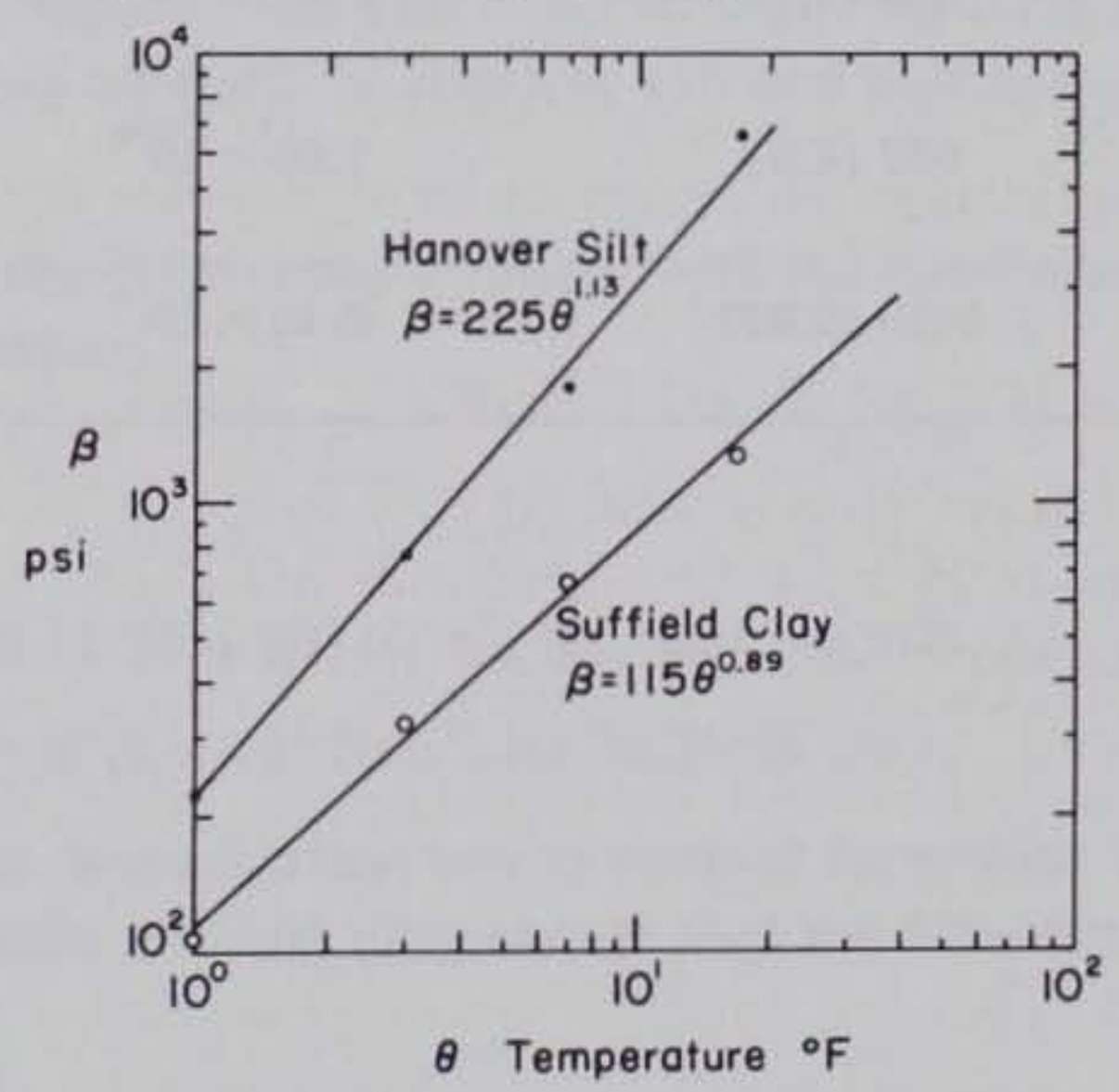

Figure 40. Temperature and $\beta$. 


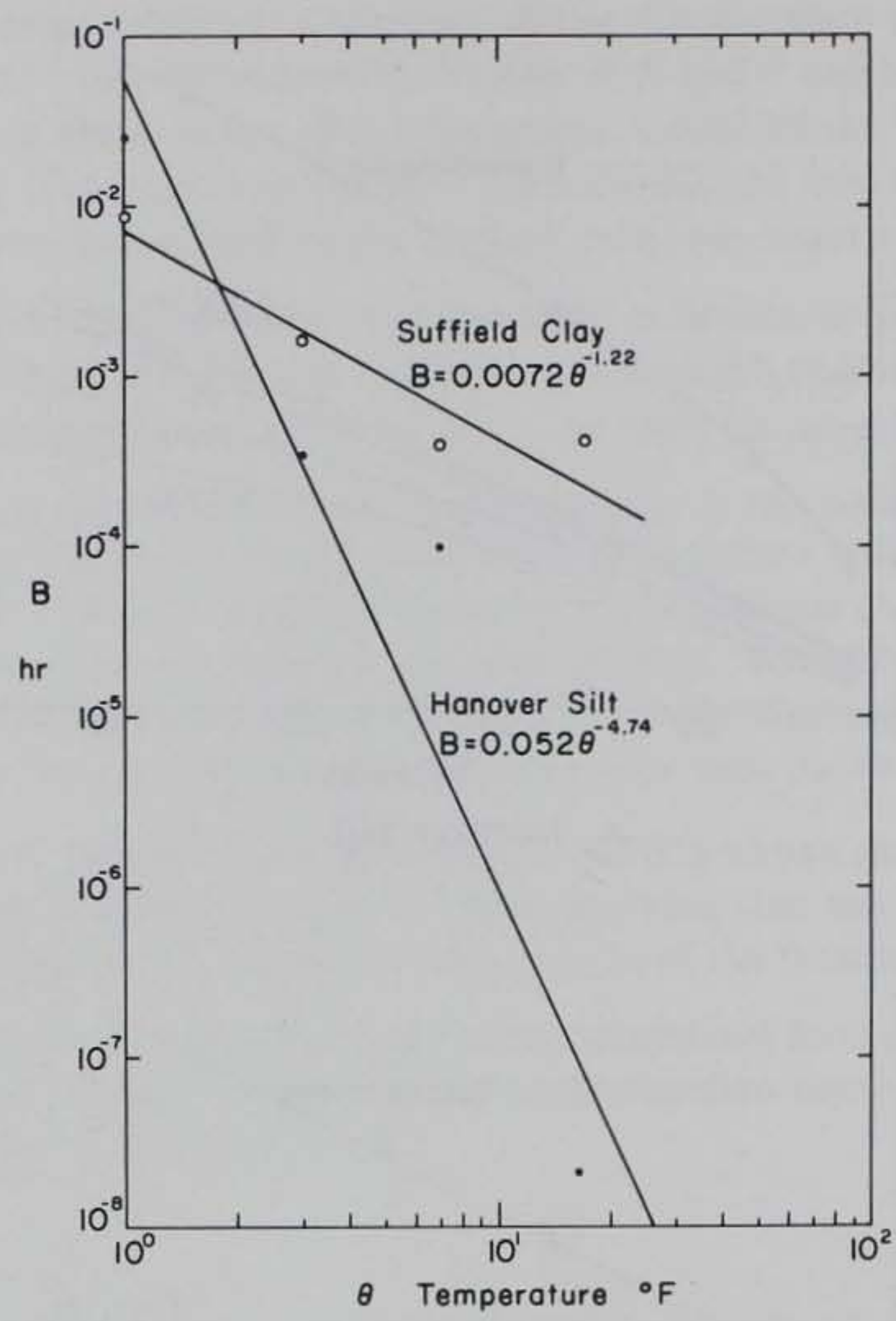

Figure 41. Temperature and $B$.

Table IX. Constants for strength equation at different temperatures.

\begin{tabular}{cccccc} 
& \multicolumn{2}{c}{ Suffield clay } & & \multicolumn{2}{c}{ Hanover silt } \\
\cline { 2 - 3 } \cline { 5 - 6 } Temp & $\begin{array}{c}B \\
(\mathrm{hr})\end{array}$ & $\begin{array}{c}\beta \\
(\mathrm{psi})\end{array}$ & & $\begin{array}{c}B \\
(\mathrm{hr})\end{array}$ & $\begin{array}{c}\beta \\
(\mathrm{psi})\end{array}$ \\
\hline $\begin{array}{c}31^{\circ} \mathrm{F} \\
\left(-0.556^{\circ} \mathrm{C}\right)\end{array}$ & $8.70 \times 10^{-3}$ & $109\left(0.751 \mathrm{MN} / \mathrm{m}^{2}\right)$ & & $2.57 \times 10^{-2}$ & $227\left(1.565 \mathrm{MN} / \mathrm{m}^{2}\right)$ \\
$\begin{array}{c}29 \\
(-1.67)\end{array}$ & $1.66 \times 10^{-3}$ & $323(2.23)$ & & $3.46 \times 10^{-4}$ & $769(5.3)$ \\
$\begin{array}{c}25 \\
(-3.89)\end{array}$ & $3.96 \times 10^{-4}$ & $667(4.6)$ & & $1.00 \times 10^{-4}$ & $1818(12.5)$ \\
$\begin{array}{c}15 \\
(9.45)\end{array}$ & $4.21 \times 10^{-4}$ & $1250(8.63)$ & & $2.15 \times 10^{-8}$ & $6667(46)$. \\
\hline
\end{tabular}

for Hanover silt:

$$
\begin{aligned}
& \beta=225 \theta^{1.13} \\
& B=0.5 \theta^{-4.75}
\end{aligned}
$$

and for Suffield clay:

$$
\begin{aligned}
& \beta=115 \theta^{0.89} \\
& B=0.0072 \theta^{-1.22}
\end{aligned}
$$

where $\beta$ is in psi, $B$ is in hours and $\theta$ in ${ }^{\circ} \mathrm{F}$. 
To estimate the creep strength of the frozen Hanover silt and Suffield clay for the temperature range of $15^{\circ}$ to $31^{\circ} \mathrm{F}\left(-9.45^{\circ}\right.$ to $\left.-0.56^{\circ} \mathrm{C}\right)$, eq $10 \mathrm{a}$ and the values for $\beta$ and $B$ computed from the preceding expression may be used.

\section{CONCLUSIONS}

The unconfined compression and unconfined compression creep tests performed in this investigation on remolded, saturated, frozen Hanover silt and Suffield clay lead to the following conclusions.

1. The variation of the unconfined compression peak (or instantaneous) strength with temperature can be represented by the expression:

$$
\sigma_{\mathrm{p}}=A\left(\frac{\theta}{\theta_{0}}\right)^{0.5}
$$

where $A$ depends on the type of soil. For estimating purposes an average value for $A$ may be taken as $250 \mathrm{psi}\left(1.725 \mathrm{MN} / \mathrm{m}^{2}\right)$ for the fine-grained soils (i.e. Hanover silt and Suffield clay) and $800 \mathrm{psi}$ $\left(5.5 \mathrm{MN} / \mathrm{m}^{2}\right)$ for sands (i.e. Ottawa sand and Manchester fine sand). The tangent modulus at $50 \%$ of the peak strength increases as the temperature decreases.

2. Unconfined compression creep strain increases with an increase in stress, temperature and time. The equations for long-term creep strain developed by Vialov (1962) and Sayles (1968) give a rough estimate of strain for long periods of time. For a constant soil temperature, a closer estimate of the long-term strain can be obtained using the expressions:

$$
\epsilon=\epsilon_{1}\left(\frac{M}{M-1}\right)\left(t^{(M-1) / M}-1\right)+\epsilon_{1} \quad \text { for } M \neq 1
$$

and

$$
\epsilon=\epsilon_{1} \ln t+\epsilon_{1} \quad \text { for } M=1
$$

where $\dot{\epsilon}_{1}$ and $M$ are obtained from creep tests lasting less than 8 hours.

3. The long-term strength is less than $45 \%$ and can be as low as $10 \%$ of the unconfined compression instantaneous strength. The long-term strength equation developed by Vialov (1962) can be used to predict the creep strength of Hanover silt and Suffield clay provided a factor of safety of at least 1.5 is used.

4. The increase in long-term creep strength with the decrease in soil temperature can be represented by the expression:

$$
\sigma=C \theta^{n}
$$

where $n=0.93 ; C=27 \mathrm{psi}\left(1.86 \times 10^{5} \mathrm{~N} / \mathrm{m}^{2}\right)$ for Hanover silt and $n=0.75 ; C=14.5 \mathrm{psi}\left(1 \times 10^{5} \mathrm{~N} / \mathrm{m}^{2}\right)$ for Suffield clay.

5. The results of this investigation are in general agreement with the findings of Vialov (1962) and ACFEL (1952) for frozen silt and clay except that the Hanover silt and Suffield clay did not 
display the classical creep curve shape reported by others for the undamped condition. It is hypothesized that the difference in the shape of the creep curves is due to the difference in the unit weight of the soil used in this investigation and also the fact that the soils used in this investigation were remolded. It is recommended that an investigation of the effect of unit weight and the remolding of soil be conducted.

It is recognized that the design and analysis of each structure in permafrost depends upon the geometric configuration of the structure, the magnitude, direction and type of loading, the type of in situ soil and the thermal regime that will exist during the life of the structure. The data and empirical methods presented in this report provide stress-strain-time relationships for frozen soil that permit this analysis and design. The amount of settlement of footings, the movement of embankments, the closure of openings in permafrost, etc. can be estimated by using the equations presented here, provided that the constants in these equations are evaluated by using data obtained from appropriate tests on undisturbed samples of the frozen soils taken from the construction site under consideration.

\section{LITERATURE CITED}

Andersland, O.B. and W. Akili (1987) Stress effect on creep rates of frozen clay. Geotechnique, vol. 17 , p. $27-39$.

Anderson, D. and A. Tice (1972) Predicting unfrozen water contents in frozen soils from surface area measurements. Session 45, 51st Annual Meeting of the Highway Research Board Symposium Frost Action in Soils.

Assur, A. (1963) Creep of frozen soil (Discussion). Proceedings, First Permafrost International Conference, Building Research Advisory Board, National Academy of Sciences, Publ. 1287, p. 339.

Arctic Construction and Frost Effects Laboratory (1952) Investigation of description, classification and strength properties of frozen soils, Vols. 1 and 2. U.S. Army Arctic Construction and Frost Effects Laboratory (ACFEL) Technical Report 40. AD 721745 and AD 721746. (Also U.S. Amy Snow, Ice and Permafrost Research Establishment (USA SIPRE) Report 8.)

Conrad, H. (1961) Experimental evaluation of creep and stress rupture. In Mechanical Behavior of Materials at Elevated Temperature (John E. Dorn, Editor). New York: McGrawHill Co., p. 149-217.

Goughnour, R.R. and O.B. Andersland (1968) Mechanical properties of a sand-ice system. Journal of Soil Mechanics, Foundations Division, ASCE, vol. 94, no. SM4, p. 923-950.

Jellinek, H.H.G, and R. Brill (1956) Viscoelastic properties of ice. Applied Physics, vol. 27 , no. 20 , p. 1198-1209.

Kauzmann, Walter (1941) Flow of solid metals from the standpoint of the chemical-rate theory. Transactions of the American Institute of Mining and Metallurgical Engineering, vol. 143, p. $57-83$.

Sanger, F.J. and C.W. Kaplar (1963) Plastic deformation of frozen soils in unconfined com* pression. Proceedings, First Permafrost International Conference, Building Research Advisory Board, National Academy of Sciences, Publ. 1287.

Sanger, F.J. (1968) Ground freezing in construction. Journal of Soil Mechanics, Foundations Division, ASCE, vol. 94, no. SM1, p. 131-158. Proc. Paper 5743.

Sayles, F.H. (1963) Constant stress compression type creep apparatus. U.S. Army Cold Regions Research and Engineering Laboratory (USA CRREL) Technical Note (unpublished). 
Sayles, F.H. (1968) Creep of frozen sand. USA CRREL Technical Report 190. AD 680902.

Tsytovich, N.A. (1954) Instructions for determining the cohesive strength of frozen soil. USA CRREL Draft Translation 162. AD 715072.

Tsytovich, N.A. (1958) Bases and foundations on frozen soil. Highway Research Board Translation, Special Report 58.

Vialov, S.S. (1959) Rheological properties and bearing capacity of frozen soils. USA SIPRE Translation 74. AD 481856.

Vialov, S.S. (1962) Strength and creep of frozen soils and calculations in ice-soil retaining structures. USA SIPRE Translation 76. AD 484093.

Vialov, S.S. and N.A. Tsytovich (1955) Cohesion of frozen soils. Dok. Akad. Nauk., no. 104, vol. 4 , p. 527-529.

Vialov, S.S. (1963) Rheology of frozen soils. Proceedings, First Permafrost International Conference, Building Research Advisory Board, National Academy of Sciences, Publ. 1287, p. 332-337. 
Table Al - Suffield Clay

Nominal Temperature $15^{\circ} \mathrm{F}$

\begin{tabular}{|c|c|c|c|c|c|c|c|c|c|c|c|c|c|}
\hline $\begin{array}{l}\text { Specimen } \\
\text { No. }\end{array}$ & $\begin{array}{r}\mathrm{Yd} \\
1 \mathrm{~b} / \mathrm{ft}^{3}\end{array}$ & $\begin{array}{c}\mathrm{Ym} \\
1 \mathrm{~b} / \mathrm{ft}^{3}\end{array}$ & $\mathrm{~s}^{++}$ & $w$ & e & $\mathrm{n}$ & $\begin{array}{l}\text { Stress } \\
1 \mathrm{~b} / \mathrm{in}^{2}\end{array}$ & $\begin{array}{c}\% \text { of } \\
\text { Inst. } \\
\text { Strength } \\
\end{array}$ & $\begin{array}{c}\text { Time } \\
20 \% \mathrm{Str} \\
\mathrm{hr} \\
\end{array}$ & $\begin{array}{l}\text { to } \\
\text { rain } \\
\end{array}$ & $\begin{array}{c}\text { Duration } \\
\text { of Test } \\
\mathrm{hr}\end{array}$ & $\begin{array}{c}\text { Strain } \\
\text { at max. } \\
\text { Stress }\end{array}$ & Remarks \\
\hline SFC 17 & 79.6 & 110.6 & 100 & .390 & 1.109 & .526 & $731 *$ & 102.8 & 28 & sect & & .0373 & \\
\hline SFC 22 & 80.8 & 111.4 & 100 & .379 & 1.078 & .519 & $691 *$ & 97.2 & 21 & sect & & .0537 & \\
\hline SFC 23 & 80.4 & 111.1 & 100 & .382 & 1.089 & .521 & $711 *$ & 100.0 & 29 & sect & & .0534 & \\
\hline SFC $112 \mathrm{~V}$ & 80.0 & 110.6 & 100 & .382 & 1.097 & .523 & 420 & 59.1 & .360 & & & & \\
\hline SFC $113 \mathrm{~V}$. & 80.0 & 110.5 & 100 & .381 & 1.098 & .523 & 420 & 59.1 & .390 & & & & \\
\hline SFC $115 \mathrm{~V}$ & 79.6 & 110.3 & 100 & .385 & 1.108 & .526 & 420 & 59.1 & .269 & & & & \\
\hline $\mathrm{SFC} 116 \mathrm{~V}$ & 80.9 & 111.0 & 99.7 & .371 & 1.075 & .518 & 280 & 39.4 & 16.5 & & & & \\
\hline SFC $120 \mathrm{~V}$ & 80.4 & 110.7 & 100 & .378 & 1.089 & .521 & 280 & 39.4 & 24.5 & & & & \\
\hline SFC $121 \mathrm{~V}$ & 78.9 & 109.7 & 100 & .391 & 1.129 & .530 & 280 & 39.4 & 15.2 & & & & \\
\hline SFC $99 \mathrm{~V}$ & 85.4 & 113.6 & 98,3 & .329 & .965 & .491 & 140 & 19.7 & & & 359 & & $\begin{array}{l}\text { Temp. failure at } \\
300 \mathrm{hrs} \text {. }\end{array}$ \\
\hline SFC $101 \mathrm{~V}$ & 84.5 & 112.7 & 99.1 & .334 & .987 & .497 & 140 & 19.7 & & & 1008 & & \\
\hline $\begin{array}{l}\text { SFC } 111 \mathrm{~V} \\
\text { SFC } 123 \mathrm{~V}\end{array}$ & $\begin{array}{l}81.3 \\
89.0\end{array}$ & 111.4 & 100. & .370 & 1.064 & .516 & 140 & 19.7 & & & 744 & & \\
\hline $\begin{array}{l}\text { SFC } 123 \mathrm{~V} \\
\text { SFC } 97\end{array}$ & $\begin{array}{l}89.0 \\
84.9\end{array}$ & $\begin{array}{l}116.6 \\
113.1\end{array}$ & $\begin{array}{l}96.9 \\
98.3\end{array}$ & $\begin{array}{l}.310 \\
.333\end{array}$ & $\begin{array}{l}.921 \\
.977\end{array}$ & $\begin{array}{l}.480 \\
.494\end{array}$ & $\begin{array}{r}140 \\
70\end{array}$ & $\begin{array}{r}19.7 \\
9.8\end{array}$ & & & $\begin{array}{r}1009 \\
336\end{array}$ & & Temp. failure at \\
\hline SF̧C 98 & 84.5 & 112.3 & 95.9 & .328 & .986 & .496 & 70 & -9.8 & & & 360 & & $\begin{array}{l}\text { Temp. failure at } \\
96 \mathrm{hrs} \text {. }\end{array}$ \\
\hline SFC 108 & 81.7 & 111.6 & 100 & .366 & 1.055 & .513 & 70 & 9.8 & & & 2160 & & \\
\hline SFC 110 & 80.4 & 110.7 & 99.9 & .376 & 1.088 & .521 & $\begin{array}{l}70 \\
35\end{array}$ & $\begin{array}{l}9.8 \\
49\end{array}$ & & & 2184 & & Temp, fíilure at \\
\hline SFC 106 & 87.6 & 115.6 & 96.0 & .319 & .951 & .487 & 35 & 4.9 & & & 1728 & & \\
\hline \multicolumn{14}{|c|}{ Average instantaneous strength $=711 \mathrm{psi}$} \\
\hline \multicolumn{4}{|c|}{$\begin{aligned} \mathrm{yd}= & \mathrm{dry} \text { unit wt. } \\
\mathrm{ym}= & \text { mass unit wt. } \\
\mathrm{S}= & \text { percent of voids filled with } \\
& \text { water (frozen \& unfrozen) }\end{aligned}$} & $\begin{array}{l}\mathrm{w}= \\
\mathrm{e}= \\
\mathrm{n}= \\
*=\end{array}$ & \multicolumn{4}{|c|}{$\begin{array}{l}\text { water content (frozen \& unfrozen) } \\
\text { void ratio } \\
\text { porosity } \\
\text { maximum stress }\end{array}$} & \multicolumn{5}{|c|}{$\begin{aligned}+ & =\text { time to max. stress } \\
\mathrm{V}= & \text { tests performed on constant } \\
& \text { stress apparatus } \\
++= & \text { see Appendix } \mathrm{B} \\
& \text { for explanation of saturation } \\
& \text { values }\end{aligned}$} \\
\hline
\end{tabular}


Table A1 - Suffield Clay (Cont.)

Nominal Temperature $25^{\circ} \mathrm{F}$

\begin{tabular}{|c|c|c|c|c|c|c|c|c|c|c|c|c|}
\hline $\begin{array}{l}\text { Specimen } \\
\text { No. }\end{array}$ & $\begin{array}{c}\gamma d \\
1 \mathrm{~b} / \mathrm{ft}^{3} \\
\end{array}$ & $\begin{array}{c}\gamma \mathrm{Ym} \\
1 \mathrm{~b} / \mathrm{ft}^{3} \\
\end{array}$ & $\mathrm{~S}^{++}$ & w & e & $\mathrm{n}$ & $\begin{array}{l}\text { Stress } \\
1 \mathrm{~b} / \mathrm{in}^{2}\end{array}$ & $\begin{array}{c}\% \text { of } \\
\text { Inst. } \\
\text { Strength }\end{array}$ & $\begin{array}{c}\text { Time to } \\
20 \% \text { Strain } \\
\mathrm{hr} \\
\end{array}$ & $\begin{array}{c}\text { Duration } \\
\text { of Test } \\
\mathrm{hr}\end{array}$ & $\begin{array}{r}\text { Strain } \\
\text { at max. } \\
\text { Stress } \\
\end{array}$ & Remarks \\
\hline SFC 3 & 84.0 & 113.4 & 100 & .351 & .999 & .500 & $452 *$ & 100.9 & & & .0532 & Recorder failure \\
\hline SFC 8 & 80.0 & 110.7 & 100 & .384 & 1.099 & .523 & $451 *$ & 100.7 & $54 \mathrm{sect}$ & & .0544 & \\
\hline SFC 12 & 80.6 & 111.1 & 100 & .379 & 1.084 & .520 & $443 *$ & 98.9 & $36 \mathrm{sect}$ & & .0543 & \\
\hline SFC $87 \mathrm{~V}$ & 79.5 & 110.2 & 99.8 & .386 & 1.112 & .527 & 273 & 60.9 & .136 & & & \\
\hline SFC $94 \mathrm{~V}$ & 81.9 & 111.9 & 100 & .365 & 1.049 & .512 & 273 & 60.9 & .117 & & & \\
\hline SFC $96 \mathrm{~V}$ & 82.3 & 112.0 & 99.7 & .361 & 1.040 & .510 & 273 & 60.9 & .106 & & & \\
\hline SFC $85 \mathrm{~V}$ & 83.0 & 112.7 & 100 & .357 & 1.021 & .505 & 182 & 40.6 & 2.92 & & & \\
\hline SFC $86 \mathrm{~V}$ & 83.0 & 112.2 & 98.9 & .352 & 1.022 & .505 & 182 & 40.6 & 1.90 & & & \\
\hline SFC $91 \mathrm{~V}$ & 82.7 & 112.4 & 100 & .360 & 1.030 & .507 & 182 & 40.6 & 2.04 & & & \\
\hline SFC $48 \mathrm{~V}$ & 80.1 & 110.7 & 100 & .383 & 1.097 & .523 & 90 & 20.1 & & 2113 & & Specimen tilted \\
\hline SFC $58 \mathrm{~V}$ & 85.9 & 114.0 & 98.4 & .328 & .955 & .488 & 90 & 20.1 & & 2280 & & \\
\hline SFC $84 \mathrm{~V}$ & 80.7 & 111.0 & 99.8 & .375 & 1.080 & .519 & 90 & 20.1 & & 696 & & $\begin{array}{l}\text { Test terminated } \\
\text { prematurely }\end{array}$ \\
\hline SFC $88 \mathrm{~V}$ & 79.4 & 110.2 & 100 & .388 & 1.114 & .527 & 90 & 20.1 & & 192 & & $\begin{array}{l}\text { Test terminated } \\
\text { prematurely }\end{array}$ \\
\hline SFC 81 & 83.5 & 112.7 & 99.5 & .350 & 1.010 & .503 & 45 & 10.0 & & 1416 & & \\
\hline SFC 92 & 80.6 & 110.1 & 96.9 & .365 & 1.082 & .520 & 45 & 10.0 & & 408 & & $\begin{array}{l}\text { Temp. failure at } \\
192 \mathrm{hrs} \text {. }\end{array}$ \\
\hline SFC 80 & 82.9 & 112.4 & 99.5 & .355 & 1.025 & .506 & 23 & 5.1 & & 1488 & & \\
\hline SFC 89 & 82.4 & 112.0 & 99.2 & .358 & 1.036 & .509 & 22 & 4.9 & & 336 & & $\begin{array}{l}\text { Temp. failure at } \\
72 \text { hrs. }\end{array}$ \\
\hline SFC 93 & 80.2 & 109.9 & 97.4 & .370 & 1.092 & .522 & 22 & 4.9 & & 408 & & \\
\hline
\end{tabular}

Average instantaneous strength $=448 \mathrm{psi}$
$\gamma \mathrm{d}=\mathrm{dry}$ unit wt.
$\gamma \mathrm{m}=$ mass unit wt.
$=$ percent of voids filled with water (frozen \& unfrozen)

$+=$ time to max. stress

$\mathrm{V}=$ tests performed on constant stress apparatus

$++=$ see Appendix B

for explanation of saturation values 
Table Al - Suffied Clay (Cont.)

Nominal Temperature $29^{\circ} \mathrm{F}$

\begin{tabular}{|c|c|c|c|c|c|c|c|c|c|c|c|c|c|}
\hline \multicolumn{2}{|c|}{$\begin{array}{l}\text { Specimen } \\
\text { No. }\end{array}$} & \multirow{2}{*}{$\frac{\begin{array}{c}\gamma d \\
1 \mathrm{~b} / \mathrm{ft}^{3}\end{array}}{79.7}$} & \multirow{2}{*}{$\begin{array}{c}\begin{array}{c}y m \\
1 \mathrm{~b} / \mathrm{ft}^{3}\end{array} \\
110.6\end{array}$} & \multirow{2}{*}{$\frac{S^{++}}{100}$} & \multirow{2}{*}{$\frac{w}{.387}$} & \multirow{2}{*}{$\frac{\mathrm{e}}{1.105}$} & \multirow{2}{*}{$\frac{\mathrm{n}}{.525}$} & \multirow{2}{*}{$\begin{array}{l}\begin{array}{c}\text { Stress } \\
\text { lb/in }\end{array} \\
344 *\end{array}$} & \multirow{2}{*}{$\begin{array}{c}\begin{array}{c}\% \text { of } \\
\text { Inst. } \\
\text { Strength }\end{array} \\
103.3\end{array}$} & $\begin{array}{l}\text { Time to } \\
20 \% \text { Strain } \\
\mathrm{hr}\end{array}$ & \multirow[t]{2}{*}{$\begin{array}{c}\text { Duration } \\
\text { of Test } \\
\mathrm{hr}\end{array}$} & \multirow[t]{2}{*}{$\begin{array}{r}\text { Strain } \\
\text { at max. } \\
\text { Stress }\end{array}$} & \multirow[t]{2}{*}{ Remarks } \\
\hline $\mathrm{SFC}$ & 11 & & & & & & & & & 32 & & & \\
\hline SFC & 16 & 79.6 & 110.4 & 99.9 & .387 & 1.108 & .526 & $321 *$ & 96.3 & 38 & & .0826 & \\
\hline SFC & $17 \mathrm{~A}$ & & & & & & & $334 \%$ & 100.3 & 62 & & .0821 & Weighing error \\
\hline $\mathrm{SFC}$ & 28 & 81.5 & 111.2 & 98.4 & .365 & 1.059 & .514 & 201 & 60.4 & .029 & & & \\
\hline SFC & 43 & 80.4 & 110.6 & 98.5 & .375 & 1.088 & .521 & 201 & 60.4 & .044 & & & \\
\hline SFC & $47 \mathrm{~V}$ & 81.5 & 111.0 & 97.6 & .362 & 1.059 & .514 & $2 \mathrm{Gl}$ & 60.4 & .115 & & & \\
\hline SFC & $66 \mathrm{~V}$ & 88.4 & 115.7 & 97.6 & .309 & .899 & .473 & 201 & 60.4 & .111 & & & \\
\hline SFC & $72 \mathrm{~V}$ & 85.3 & 113.9 & 98.9 & .336 & .968 & .492 & 201 & 60.4 & .069 & & & \\
\hline SFC & $69 \mathrm{~V}$ & 85.6 & 114.2 & 98.8 & .333 & .960 & .490 & 134 & 40.2 & .36 & & & \\
\hline SFC & $71 \mathrm{~V}$ & 86.7 & 115.1 & 99.6 & .328 & .937 & .484 & 134 & 40.2 & .34 & & & \\
\hline SFC & $33 \mathrm{~V}$ & 81.2 & 110.5 & 96.3 & .360 & 1.067 & .516 & 67 & 20.1 & 145.0 & & & \\
\hline SFC & $37 \mathrm{~V}$ & 79.9 & 110.2 & 98.4 & .379 & 1.101 & .524 & 67 & 20.1 & 480.0 & & & \\
\hline SFC & $40 \mathrm{~V}$ & 79.7 & 110.2 & 99.2 & .384 & 1.107 & .525 & 67 & 20.1 & 167.0 & & & \\
\hline SFC & 1 & 85.2 & 113.5 & 97.2 & .331 & .969 & .492 & 33.5 & 10.0 & & 3984 & & \\
\hline SFC & 29 & 81.4 & 111.0 & 97.8 & .364 & 1.062 & .515 & 33.5 & 10.0 & & & & Testing machine failure \\
\hline SFC & 46 & 80.2 & 110.9 & 100 & .383 & 1.093 & .522 & 33.5 & 10.0 & & 1584 & & Eanrune rariations \\
\hline SFC & 52 & 86.0 & 114.5 & 99.0 & .331 & .952 & .488 & 33 & 10,0 & & 312 & & $\begin{array}{l}\text { Temp. failure at } \\
170 \text { hours }\end{array}$ \\
\hline SFC & 51 & 86.4 & 114.8 & 99.4 & .329 & .942 & .485 & 15 & 4.5 & & 650 & & Temp: variations \\
\hline SFC & 60 & & & & & & & 15 & 4.5 & & 672 & & Weighing error \\
\hline SFC & 64 & 87.4 & 115.0 & 97.3 & .315 & .920 & .479 & 15 & 4.5 & & 1392 & & \\
\hline SFC & 70 & 86.1 & 114.5 & 99.0 & .330 & .949 & .487 & 15 & 4.5 & & 1464 & & \\
\hline $\mathrm{SFC}$ & 78 & 79.5 & 110.0 & 98.5 & .383 & 1.111 & .526 & 6 & 1.8 & & 792 & & \\
\hline
\end{tabular}

Average instantaneous strength $=333 \mathrm{psi}$

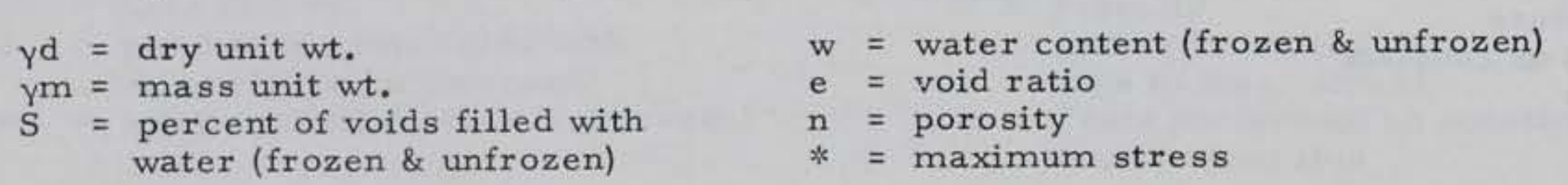

$+=$ time to max. stress

$V=$ tests performed on constant stress apparatu.

$++=$ see Appendix B

for explanation of saturation values 
Table Al - Suffield Clay (Cont.)

Nominal Terperature $31^{\circ} \mathrm{F}$

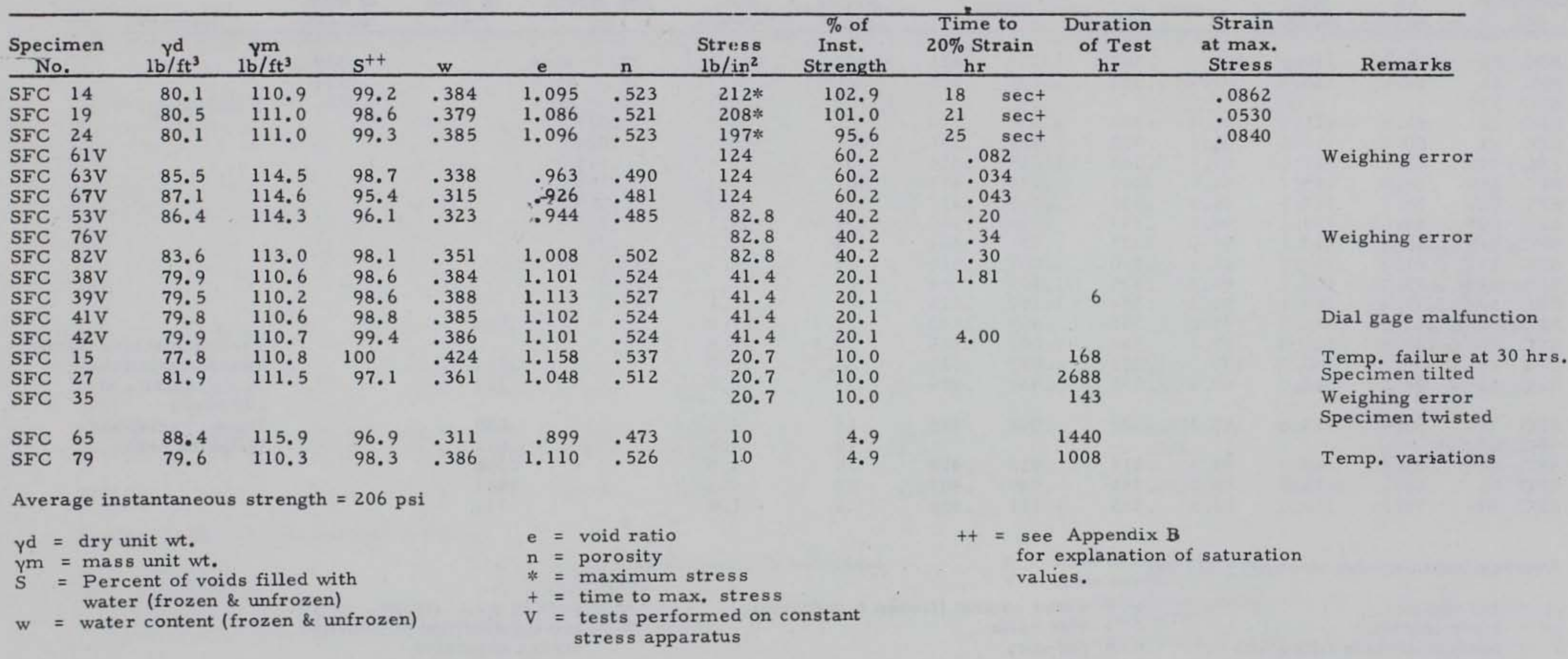


Table A2 - Hanover Silt

Nominal Temperature $15^{\circ} \mathrm{F}$

\begin{tabular}{|c|c|c|c|c|c|c|c|c|c|c|c|c|c|}
\hline $\begin{array}{c}\text { Specir } \\
\text { No } \\
\end{array}$ & men & $\begin{array}{r}\gamma d \\
1 \mathrm{~b} / \mathrm{ft}^{3} \\
\end{array}$ & $\begin{array}{c}y m \\
1 \mathrm{~b} / \mathrm{ft}^{3} \\
\end{array}$ & $\mathrm{~S}^{++}$ & w & e & n & $\begin{array}{l}\text { Stress } \\
\mathrm{lb} / \mathrm{in}^{2}\end{array}$ & $\begin{array}{c}\% \text { of } \\
\text { Inst. } \\
\text { Strength }\end{array}$ & $\begin{array}{c}\text { Time to } \\
20 \% \text { Strain } \\
\text { hr }\end{array}$ & $\begin{array}{c}\text { Duration } \\
\text { of Test } \\
\mathrm{hr}\end{array}$ & $\begin{array}{l}\text { Strain } \\
\text { at max. } \\
\text { Stress }\end{array}$ & Remarks \\
\hline HAS & 1 & 89.9 & 117.3 & 98.9 & .302 & .903 & .474 & $1389 *$ & 99.9 & $102 \mathrm{sect}$ & & .166 & \multirow{8}{*}{ Recorder malfunction } \\
\hline HAS & 2 & 89.3 & 116.9 & 99.9 & .309 & .915 & .478 & $1419 *$ & 102.0 & $109 \mathrm{sect}$ & & .122 & \\
\hline HAS & 3 & 89.8 & 117.4 & 99.5 & .304 & .904 & .475 & $1366 *$ & 98.2 & $96 \mathrm{sect}$ & & .118 & \\
\hline HAS 1 & 106 & 87.6 & 115.6 & 100 & .330 & .951 & .487 & 1020 & 73.3 & & & & \\
\hline HAS & 52 & 86.8 & 115.3 & 99.8 & .327 & .969 & .492 & 1000 & 71.9 & .053 & & & \\
\hline $\begin{array}{l}\text { HAS } \\
\text { HAS }\end{array}$ & $\begin{array}{l}74 \\
75\end{array}$ & $\begin{array}{l}87.8 \\
87.6\end{array}$ & $\begin{array}{l}115.9 \\
115.8\end{array}$ & $\begin{array}{l}100 \\
99.6\end{array}$ & $\begin{array}{r}.321 \\
320\end{array}$ & $\begin{array}{r}.947 \\
951\end{array}$ & $\begin{array}{r}.486 \\
487\end{array}$ & $\begin{array}{l}1000 \\
1000\end{array}$ & $\begin{array}{l}71.9 \\
71.9\end{array}$ & $\begin{array}{l}.102 \\
.103\end{array}$ & & & \\
\hline HAS 1 & 130 & 89.4 & 116.8 & 99.5 & .307 & .913 & .477 & 800 & $\begin{array}{l}1.9 \\
57.5\end{array}$ & 5.4 & & & \\
\hline HAS 1 & 132 & 90.6 & 116.7 & 100 & .309 & .887 & .470 & 800 & 57.5 & 6.7 & & & \\
\hline HAS 1 & 133 & 88.6 & 116.3 & 99.7 & .313 & .929 & .482 & 797 & 57.3 & & & & \multirow{12}{*}{$\begin{array}{l}\text { Irregular Pressure } \\
\text { Temp. failure at } 72 \mathrm{hrs.} \\
\text { Dial gage sticking } \\
\text { Weighing error } \\
\text { Air pressure failure } \\
\text { Test stopped - loading } \\
\text { cable caught on pin }\end{array}$} \\
\hline HAS & 80 & 90.1 & 116.8 & 97.3 & .295 & .897 & .473 & 600 & 43.1 & & 72 & & \\
\hline HAS & 98 & 83.5 & 112.1 & 96.8 & .343 & 1.049 & .512 & 600 & 43.1 & & 144 & & \\
\hline HAS 1 & 126 & & & & & & & 600 & 43.1 & & 1462 & & \\
\hline HAS & 53 & 88.2 & 116.1 & 100 & .318 & .939 & .484 & 585 & 42.0 & & 163 & & \\
\hline HAS & $10 \mathrm{~V}$ & 90.5 & 117.1 & 97.8 & .294 & .889 & .471 & 330 & 23.7 & & 1080 & & \\
\hline HAS & $23 \mathrm{~V}$ & 88.4 & 116.2 & 99.4 & .314 & .935 & .483 & 330 & 23.7 & & & & \\
\hline HAS & $24 \mathrm{~V}$ & 88.7 & 116.5 & 99.8 & .313 & .928 & .481 & 330 & 23.7 & & 1104 & & \\
\hline HAS & 20 & 87.8 & 115.9 & 99.9 & .320 & .948 & .487 & 200 & 14.4 & & 840 & & \\
\hline HAS & 21 & 88.2 & 116.2 & 100 & .317 & .938 & .484 & 200 & 14.4 & & 840 & & \\
\hline HAS & 4 & 89.2 & 117.0 & 100 & .311 & .918 & .479 & 160 & 11.5 & & 1200 & & \\
\hline HAS & 9 & 90.1 & 117.4 & 99.5 & .302 & .898 & .473 & 100 & 7.2 & & 840 & & \\
\hline
\end{tabular}

Average instantaneous strength $=1391 \mathrm{psi}$

$\gamma d=$ dry unit wt.

$\gamma \mathrm{m}=$ mass unit wt.

= percent of voids filled with

water (frozen \& unfrozen)

$\mathrm{w}=$ water content (frozen \& unfrozen) e $=$ void ratio

= maximum stress

time to max. stres

Tests performed on constant
$++=$ see Appendix B

for explanation of saturation

values 
Table A2 - Hanover Silt (Cont.)

Nominal Ternperature $25^{\circ} \mathrm{F}$

\begin{tabular}{|c|c|c|c|c|c|c|c|c|c|c|c|c|}
\hline $\begin{array}{l}\text { Specimen } \\
\text { No. }\end{array}$ & $\begin{array}{c}y d \\
1 \mathrm{~b} / \mathrm{ft}^{3} \\
\end{array}$ & $\begin{array}{c}\mathrm{ym} \\
1 \mathrm{~b} / \mathrm{ft}^{3} \\
\end{array}$ & $\mathrm{~S}^{++}$ & w & e & $\mathrm{n}$ & $\begin{array}{l}\text { Stress } \\
\mathrm{lb} / \mathrm{i} \mathrm{i}^{2}\end{array}$ & $\begin{array}{c}\% \text { of } \\
\text { Inst. } \\
\text { Strength } \\
\end{array}$ & $\begin{array}{l}\text { Time to } \\
20 \% \text { Strain } \\
\mathrm{hr}\end{array}$ & $\begin{array}{c}\begin{array}{c}\text { Duration } \\
\text { of Test } \\
\mathrm{hr}\end{array} \\
\end{array}$ & $\begin{array}{r}\text { Strain } \\
\text { at max. } \\
\text { Stress } \\
\end{array}$ & Remarks \\
\hline HAS 108 & 86.9 & 115.1 & 99.2 & .325 & .968 & .492 & $821 *$ & 101.2 & & & .141 & Recorder failure \\
\hline HAS 109 & 86.7 & 115.0 & 99.3 & .327 & .973 & .493 & $822 *$ & 101.4 & $79 \mathrm{sect}$ & & .132 & Necorder tanure \\
\hline HAS 112 & 85.2 & 113.9 & 99.2 & .338 & 1.007 & .502 & $828 *$ & 102.1 & $63 \mathrm{sect}$ & & .125 & \\
\hline HAS 114 & & & & & & & $772 *$ & 95.2 & $106 \mathrm{sect}$ & & .212 & Weighing error \\
\hline HAS $29 \mathrm{~V}$ & 88.3 & 116.3 & 100 & .318 & .936 & .483 & 490 & 60.4 & .469 & & & \\
\hline HAS $67 \mathrm{~V}$ & 87.7 & 116.1 & 100 & .322 & .949 & .487 & 490 & 60.4 & .359 & & & \\
\hline HAS $68 \mathrm{~V}$ & 88.0 & 116.0 & 100 & .321 & .942 & .485 & 490 & 60.4 & .305 & & & \\
\hline HAS $42 \mathrm{~V}$ & 89.2 & 116.7 & 99.2 & .308 & .917 & .478 & 400 & 49.3 & 7.0 & & & \\
\hline HAS $33 \mathrm{~V}$ & 88.3 & 116.4 & 100 & .318 & .937 & .484 & 330 & 40.7 & & 2858 & & \\
\hline HAS $36 \mathrm{~V}$ & 88.4 & 116.0 & 99.6 & .315 & .934 & .483 & 330 & 40.7 & & 441 & & \\
\hline HAS $7 \mathrm{~V}$ & & & & & & & 300 & 37.0 & & 100 & & Temp. failure at $100 \mathrm{hrs}$. \\
\hline HAS $11 \mathrm{~V}$ & 89.2 & 116.9 & 100 & .311 & .917 & .478 & 300 & 37.0 & & 100 & & Temp. failure at $100 \mathrm{hrs}$. \\
\hline HAS 32 & 88.9 & 116.2 & 99.7 & .312 & .924 & .480 & 200 & 24. 7 & & 4369 & & \\
\hline HAS 41 & 89.1 & 116.2 & 100 & .313 & .918 & .479 & 200 & 24.7 & & 4322 & & \\
\hline HAS 38 & 88.0 & 115.8 & 98.6 & .315 & .943 & .485 & 160 & 19.7 & & 1705 & & $\begin{array}{l}\text { Temp. control relay } \\
\text { switch malfunction }\end{array}$ \\
\hline HAS 6 & 89.2 & 116.6 & 98.6 & .307 & .917 & .478 & 150 & 18.5 & & 485 & & \\
\hline HAS 14 & 88.4 & 116.6 & 100 & .318 & .934 & .483 & 150 & 18.5 & & 504 & & \\
\hline HAS 12 & 88.2 & 116.0 & 98.8 & .314 & .938 & .484 & 100 & 12.3 & & 504 & & , \\
\hline HAS 34 & 90.0 & 116.2 & 95.5 & .290 & .899 & .473 & 100 & 12.3 & & 1705 & & , \\
\hline HAS 102 & 86.5 & 114.7 & 100 & .331 & .976 & .494 & 100 & 12.3 & & 1440 & & \\
\hline HAS 17 & & & & & & & 50 & 6.2 & & 504 & & Weighing error \\
\hline
\end{tabular}

Average instantaneous strength $=811 \mathrm{psi}$

$\begin{array}{ll}\gamma d=\text { dry unit wt. } & w=\text { water content (frozen \& unfrozen) } \\ \gamma \mathrm{m}=\text { mass unit wt. } & \mathrm{e}=\text { void ratio } \\ \mathrm{S}=\text { percent of voids filled with } & \mathrm{n}=\text { porosity }\end{array}$

$+=$ time to max. stress

water (frozen \& unfrozen) $\quad$ = maximum stress
$\mathrm{V}=$ tests performed on :onstant stress apparatus
++ iee Appendix B
for explanation of saturation values


Table A2 - Hanover Silt (Cont.)

Nominal Teraperature $29^{\circ} \mathrm{F}$

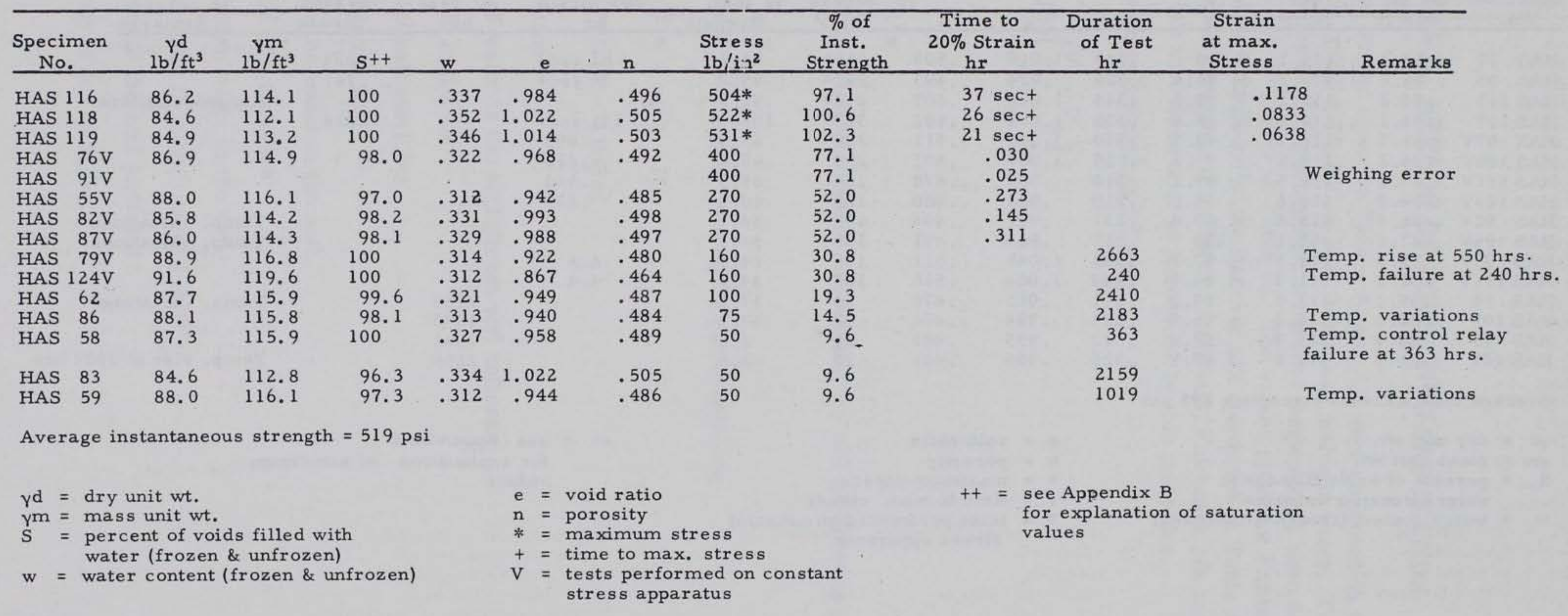


Table A2 - Hanover Silt (Cont.)

Nominal Teraperature $31^{\circ} \mathrm{F}$






\section{APPENDIX B. METHOD OF COMPUTING SATURATION}

The percent saturation values listed in Tables AI and AII were computed on the basis of the total water in the specimen being composed of both frozen and unfrozen water. The amounts of unfrozen water in Suffield clay and Fairbanks silt at the test temperatures were determined by Anderson and Tice (1971) and are listed in Table BI. The values given for Fairbanks silt were used to determine the percent saturation for the Hanover silt specimens in Table AII since this type of data was available for Hanover silt. The two materials, Fairbanks silt and Hanover silt, are very similar and it is felt that little error is introduced by this procedure.

Percent saturations were calculated as follows:

$$
S=100\left(\frac{V_{\mathrm{w}}}{V_{\mathrm{v}}}\right)=100\left(\frac{V_{\mathrm{I}}+V_{\mathrm{u}}}{e V_{\mathrm{s}}}\right)
$$

where

$$
\begin{aligned}
& V_{\mathrm{s}}=W_{\mathrm{s}} /\left(G_{\mathrm{s}} \gamma_{\mathrm{w}}\right) \\
& V_{\mathrm{I}}=W_{\mathrm{s}}(w-a) / G_{\mathrm{I}} \gamma_{\mathrm{w}}
\end{aligned}
$$

and assuming that the density of unfrozen water surrounding the soil particles is $1 \mathrm{~g} / \mathrm{cm}^{3}(62.4 \mathrm{lb} /$ $\mathrm{ft}^{3}$ )

then: $\quad V_{\mathrm{u}}=W_{\mathrm{u}} / \gamma_{\mathrm{w}}=a W_{\mathrm{s}} / \gamma_{\mathrm{w}}$

substituting expressions for $V_{\mathrm{s}}, V_{\mathrm{I}}$ and $V_{\mathrm{u}}$ into eq $\mathrm{B} 1$ and simplifying

$$
\begin{aligned}
& S=100\left[G_{\mathrm{s}} /\left(G_{\mathrm{I}} e\right)\right]\left[w+a\left(G_{\mathrm{I}}-1\right)\right] \\
& S=100\left[G_{\mathrm{s}} /(0.917 e)\right][w-0.083 a]
\end{aligned}
$$

where $S=$ percent saturation

$V_{\mathrm{w}}=$ total volume of water in the soil, frozen and unfrozen

$V_{\mathrm{v}}=$ volume of voids in the soil

$V_{\mathrm{s}}=$ volume of solid soil particles

$V_{\text {I }}=$ volume of ice in the soil

$V_{\mathrm{u}}=$ volume of unfrozen water in the soil

$W_{\mathrm{s}}=$ weight of solid soil particles

$W_{\mathrm{u}}=$ weight of unfrozen water in the soil

$\gamma_{\mathrm{w}}=$ unit weight of water $\left(1 \mathrm{~g} / \mathrm{cm}^{3}\right)$ or $62.4 \mathrm{lb} / \mathrm{ft}^{3}$

$G_{\mathrm{s}}=$ specific gravity of the soil particles

$G_{\mathrm{I}}=$ specific gravity of ice $(0.917)$ 
$e=$ void ratio

$w=$ water content

$\alpha=$ ratio of the weight of unfrozen water to the weight of soil particles $\left(W_{\mathrm{u}} / W_{\mathrm{s}}\right)$.

Many of the percent saturation values in Tables AI and AII are shown to be equal to $100 \%$.

In reality these saturation values are probably slightly less than $100 \%$ but are measured to be $100 \%$ within the precision of our measuring system.

Table BI.

\begin{tabular}{|c|c|c|c|}
\hline \multicolumn{2}{|c|}{ Suffield clay } & \multicolumn{2}{|c|}{ Fairbanks silt } \\
\hline $\begin{array}{l}\text { Temp } \\
\left({ }^{\circ} \mathrm{F}\right)\end{array}$ & $\begin{array}{c}\text { Unfrozen } \\
\text { water per } \\
\text { dry wt of } \\
\text { soil }(a)\end{array}$ & $\begin{array}{c}\text { Temp } \\
\left({ }^{\circ} \mathrm{F}\right)\end{array}$ & $\begin{array}{c}\text { Unfrozen } \\
\text { water per } \\
\text { dry wt of } \\
\text { soil (a) }\end{array}$ \\
\hline 15 & .069 & 15 & .023 \\
\hline 25 & .091 & 25 & .031 \\
\hline 29 & .118 & 29 & .041 \\
\hline 31 & 168 & 31 & .059 \\
\hline
\end{tabular}




\section{DOCUMENT CONTROL DATA - R \& D}

Security classilication of tilte, body of abstract and indexing annotation must be ontered when the overall report is clasallied)

U.S. Army Cold Regions Research and

Engineering Laboratory

Hanover, New Hampshire 03755

3. REPORT TITLE

CREEP OF FROZEN SILT AND CLAY

4. OESCRIPTIVE NOTES (TYPe of report and incluaive dates)

5. AUTHOR(S) (First name, middlo inltial, last name)

Francis H. Sayles and Duane Haines

\begin{tabular}{|c|c|c|}
\hline $\begin{array}{l}\text { O. REPOK I DATE } \\
\text { July } 1974\end{array}$ & $\begin{array}{l}\text { 7a. TOTAL NO. OF PAGES } \\
54\end{array}$ & $\begin{array}{r}\text { 7b. NO. OF REFS } \\
18\end{array}$ \\
\hline B. ONTRACT ORGRANTINO & 9a. ORIGINAT & \\
\hline
\end{tabular}

b. HEIJECT NO

DA Project 4A162121A894

Technical Report 252

Task 23, Work Unit 002 9b. OTHER REPORT NO(S) (Any other numbers that may bo asaigned
this roport)

i.

10 DISTRIGISTION STATEMENT

Approved for public release; distribution unlimited.

11. SUPPLEMENTARY NOTES
Directorate of Military Construction
Office, Chief of Engineers
Washington, D.C.

Unconfined compressive creep strengths and strains were measured for remolded saturated frozen Hanover silt and Suffield clay. The creep tests were conducted at the approximate stress levels of $60,35,20$ and $5 \%$ of the conventional unconfined compressive strength. Testing temperatures were $15^{\circ}, 25^{\circ}, 29^{\circ}$ and $31^{\circ} \mathrm{F}\left(-9.45^{\circ},-3.89^{\circ},-1.67^{\circ}\right.$ and $\left.-0.56^{\circ} \mathrm{C}\right)$. It was found that the variation of unconfined compression peak strength with temperature can be represented by $\sigma_{p}=A\left(\theta / \theta_{0}\right)^{0.5}$. Unconfined compression creep strength can be estimated by Vialov's strength equation. Long-term creep strength is less than $45 \%$ of unconfined compression strength and can be as low as $10 \%$ of this strength. The increase in long-term creep strength with the decrease in soil temperature can be represented by $\sigma=C \theta^{n}$. A close estimate of the long-term creep strain can be obtained from the expression $\epsilon=\dot{\epsilon}_{1}(M / M-1)\left(t^{M-1 / M}-1\right)+\epsilon_{1}$ for $M \neq 1$, and $\epsilon=\dot{\epsilon}_{1} \ln t+\epsilon_{1}$ for $M=1$. The results of this investigation are in general agreement with findings of other investigators for frozen silt and clay except that Hanover silt and Suffield clay did not display the classical creep curve shape. $(\theta=$ temperature in degrees below the freezing point of water; $\theta_{0}=$ reference temperature $(\theta)$ greater than zero; $A, C$ and $n$ are constants; $\epsilon=$ strain; $\epsilon_{1}=$ strain at one hour; $\dot{\epsilon}_{1}=$ strain rate at one hour; $t=$ elapsed time; and $M$ is a constant obtained from short-term creep tests.)

14. Key Words

$\begin{array}{llll}\text { Clays } & \text { Creep tests } & \text { Permafrost } & \text { Soil mechanics } \\ \text { Creep strength } & \text { Frozen soils } & \text { Silts } & \end{array}$

